\title{
1 Title: Butterfly eyespots evolved via co-option of the antennal gene-regulatory network
}

3 Authors: Suriya Narayanan Murugesan ${ }^{1, *}+$, , Heidi Connahs ${ }^{1,}{ }^{*}, \dagger$, Yuji Matsuoka ${ }^{1,} \uparrow$, Mainak

4 das Gupta $^{1}$, Manizah Huq ${ }^{1}$, V Gowri $^{1}$, Sarah Monroe ${ }^{1}$, Kevin D. Deem², Thomas Werner ${ }^{3}$,

5 Yoshinori Tomoyasu², Antónia Monteiro ${ }^{1,4, *}$

\section{Affiliations:}

7 1- Department of Biological Sciences, National University of Singapore

8 2- Department of Biology, Miami University, USA

9 3- Department of Biological Sciences, Michigan Technological University, USA

10 4- Science Division, Yale-NUS College, Singapore

$11 \uparrow$ - Equal contributions

$12 *_{\text {- }}$ Authors of correspondence

13 Email: suriya_nm@u.nus.edu,dbshc@nus.edu.sg, antonia.monteiro@nus.edu.sg

Abstract: Butterfly eyespots are beautiful novel traits with an unknown developmental origin.

Here we show that eyespots likely originated via co-option of the antennal gene-regulatory network (GRN) to novel locations on the wing. Using comparative transcriptome analysis, we show that eyespots cluster with antennae relative to multiple other tissues. Furthermore, three genes essential for eyespot development (Distal-less (Dll), spalt (sal), and Antennapedia (Antp)) share similar regulatory connections as those observed in the antennal GRN. CRISPR knockout of cis-regulatory elements (CREs) for Dll and sal led to the loss of eyespots and antennae, and also legs and wings, demonstrating that these CREs are highly pleiotropic. We implicated also in the development of legs and wings. 
Main text:

27 Although the hypothesis of GRN co-option is a plausible model to explain the origin of morphological novelties (1), there has been limited empirical evidence to show that this mechanism led to the origin of any novel trait. Several hypotheses have been proposed for the origin of butterfly eyespots, a novel morphological trait. These include GRN co-option from the leg (2), embryo segmentation (3), wing margin (4) and wound healing (5). These hypotheses for eyespot GRN origins all rely on similarities of expression of just a few candidate genes observed in eyespots and in the proposed ancestral gene network. To test whether cooption of any of these networks underlies eyespot origins, we focused on the nymphalid butterfly Bicyclus anynana, which has served as a model for studying eyespot development (6). Using RNA-sequencing (RNA-seq), we examined and compared the larger collection of genes expressed in a forewing eyespot of $B$. anynana with those expressed in these proposed candidate ancestral traits. Additionally, we examined a few other traits, including larval head horns and prolegs, and also pupal eyes and antennae (Fig. 1A).

\section{The transcriptome profile of eyespots and antennae cluster together}

We first examined which of the sampled tissues shared the most similar gene expression profile to eyespot tissue, as these should cluster closer together (7). Pairwise differential expression (DE) analysis using DESeq2 (8) identified 10,281 DE genes $(\operatorname{logFC} \geq|2|$ and padj $\leq 0.001)$ among all tissues sampled. Hierarchical clustering of tissues, using DE genes, resulted in eyespots clustering with antennae (Fig. 1B), but tissues were also clustering according to

47 developmental stage (Fig. 1B, 1C). To circumvent the strong developmental stage signal, we reanalyzed DE genes solely from 3-h-old pupae, when the eyespot tissue was dissected. We found 3,839 DE genes between the tissues, with eyespots clustering with antennae, and both 
forming an outgroup to the remaining tissues with a high approximately unbiased (AU) $P$-value

51 (9) (Fig. 1D).

52 To more narrowly identify the subset of genes associated with eyespot development and to 53 examine similarities in their expression profile with our candidate tissues, we next compared

54 the transcriptome of dissected eyespot tissue with adjoining control tissue in the same wing 55 sector (Fig. 1A), as done by a previous study (10). This previous study identified 183 genes differentially expressed in eyespots relative to sectors of the wing without eyespots. Our new DE analysis between eyespot and control wing tissues identified 652 eyespot-specific DE genes with 370 being up-regulated, which included sal, and 282 down-regulated in eyespots (Fig. S1, S2, Spreadsheet S1). We mapped the published 183 eyespot DE genes, which included Dll and Antp, to the current assembled transcriptome. After removing multi-mapped genes, we retained 144 genes from the published study for further analysis (Spreadsheet S1). When hierarchical clustering was performed, using either the newly identified 652 genes, the 144 genes previously identified, or both datasets combined, we found that the eyespot transcriptome always clustered with antennae with strong support AU $P$-value for the clade. This clustering persisted with just the 370 up-regulated genes (Fig. S3A, E, F).

67 Given the importance of transcription factors (TFs) in development and in establishing GRNs, we used 336 genes annotated as having "DNA-binding transcription factor activity (GO:0003700)" and "transcription factor binding (GO:0008134)" in a separate analysis, which 70 showed eyespots again clustering with antennae (Fig. S3B). Annotation and gene enrichment 71 for the DE genes $(3,839)$ between the 3-h-pupal stage tissues showed a strong enrichment in 72 animal organ morphogenesis (GO:0009887) and anatomical structure formation (GO:2000026)

73 (Fig. S4). Performing the clustering analysis using genes from these two groups (GO:0009887 74 and GO:2000026), in two separate analyses, reproduced the same results as the full gene set, 
indicating that these morphogenesis genes show similar expression profiles in both eyespots and antennae (Fig. S3C, 3D).

These analyses showed that eyespots and antennae form an outgroup to the other tissues, including legs, which are considered serial homologs to antennae. However, eyespots express a key selector gene, Antp which is known to give legs their unique identity and differentiate them from antennae. Antp protein is known to positively regulate $D l l$ and repress $s a l$ in the leg disc of Drosophila $(11,12)$, whereas in the antennae, in the absence of Antp, Dll activates sal (13). Comparative data across 23 butterfly species suggested that eyespots originated without Antp protein expression, and that Antp was recruited later to the eyespot GRN in at least two separate lineages, including in the ancestors of B. anynana (14). We therefore reasoned that if eyespots are co-opted antennae, rather than co-opted legs, the regulatory interactions between Dll, Sal, and Antp in eyespots should resemble those in insect antennae but not those in legs, and that the regulatory interactions between Antp and the other two genes should be novel and not homologous.

\section{Function of sal and regulatory interactions between $\mathrm{Dll}$, sal, and Antp in eyespots}

Before establishing regulatory interactions between the three genes, we first obtained missing functional data for one of these genes, sal, lacking for B. anynana. Mutations for Dll and Antp were previously shown to remove eyespots, pointing to these genes as necessary for eyespot development $(6,15)$. We disrupted the function of sal, using CRISPR with a single guide RNA (sgRNA) targeting exon 2 (Fig. S5). sal crispants (mosaic mutants) showed a range of phenotypes, from missing eyespots (Fig. 2B and 2D, Fig. S6) to altered chevron patterns on the wing margin and the central symmetry system bands running the length of each wing (Fig. 2B), all mapping to patterns of sal expression in larval and pupal wings (Fig. $2 \mathrm{H}, 2 \mathrm{~K})(5,16)$. 
100 Our data confirmed phenotypes previously shown in J. coenia (17). However, two novel and striking phenotypes were the splitting of eyespot centers into two smaller centers (Fig. 2D, Fig. S6) and the partial loss of black scales in the eyespot and their replacement with orange scales (Fig. 2D), resembling the "goldeneye" phenotype (18). Taken together, these results confirm that sal is necessary for the development of eyespots and also for the development of black scales.

To test the regulatory hierarchy between these three eyespot-essential genes, we knocked out each gene in turn, using CRISPR-Cas9, and reared the mosaic individuals until the late $5^{\text {th }}$ instar for larval wing dissections. We performed immunohistochemistry on these wings with antibodies against the protein of the targeted gene and against the other two proteins. We first examined the interaction of Dll with Antp. In wild-type (wt) wings, Dll protein is expressed along the wing margin and in finger-like patterns, spreading from the wing margin to the future eyespot centers (Fig. 2E), whereas Antp protein is initially expressed in the center of four putative eyespots (from M1 to Cu1) (19). In a Dll crispant forewing, Antp protein expression

114 was affected in Dll null cells (Fig. 2F, Fig. S7), whereas Dll protein expression was not affected in Antp null cells in an Antp crispant (Fig. 2G, Fig. S8). These results suggest that Dll is upstream of Antp in eyespot development. We next examined the interaction of $D l l$ with sal.

117 In wt wings, Sal protein is broadly expressed along several wing sectors, connected to its role 118 in vein patterning (16), and also expressed in nine potential eyespot centers (Fig. $2 \mathrm{H}$ and $2 \mathrm{~K}$ ).

119 In $D l l$ crispants, Sal expression was lost in $D l l$ null clones in the eyespot centers (Fig. 2I, Fig. 120 S9), but Dll protein expression was not affected in sal null clones in sal crispants (Fig. 2J, Fig.

$121 \mathrm{~S} 10)$. These results suggest that $D l l$ is also upstream of $s a l$ in eyespots. Finally, we examined

122 the interaction between Antp and sal. In Antp crispants, Sal protein expression is missing from 123 Antp null cells (Fig. 2L, Fig. S11). Furthermore, Antp protein expression is missing from sal 124 null cells in sal crispants (Fig. 2M, Fig. S12). Taken together, Dll is up-regulating both Antp 

$2 \mathrm{~N})$.

127

and sal, and Antp and sal are up-regulating each other's expression in forewing eyespots (Fig.

\section{Regulatory connections between $\mathrm{Dll}$ and sal in eyespot development are similar to those}

\section{in the antennae of flies}

We next examined whether the appendage expression and regulatory connections between these three genes of $B$. anynana matched those known in fly leg and antennal development. In flies, Dll protein is expressed in both appendages (20), whereas Sal is only expressed in antennae and Antp only in legs of flies (13). In B. anynana we observed similar expression profiles in antennae and thoracic legs of pupae (Fig. S13-S14). D1l is necessary for sal expression in antennae of flies (13), as also observed in B. anynana eyespots (Fig. 21). Antp, however, negatively regulates sal expression in fly legs (12), which differs from the regulation observed in eyespots, where Antp and sal up-regulate each other (Fig. 2N). The genetic interaction of Antp and Dll during leg development in Drosophila is stage-dependent. At the stage when leg primordia are formed, Antp positively regulates $D l l$ expression in the thoracic leg bud (11), but when leg segments are being formed, Dll negatively regulates Antp in the distal leg elements (21). These regulatory interactions between $D l l$ and Antp in leg development are distinct from the regulatory interaction observed in eyespots (Fig. 2N). Taken together, these data suggest that the regulatory interactions between $D l l$ and sal in eyespots are likely homologous to those in the insect antenna GRN. Antp established a novel regulatory interaction to these two genes in eyespots, distinct from those found in the leg GRN of Drosophila. This supports the later and independent addition of Antp to the eyespot GRN in two separate lineages of butterflies, as proposed by Oliver et al. (2012) (14). 
149 Two pleiotropic CREs reveal a shared network between eyespots, antennae, and other traits

151 Evidence of GRN co-option is bolstered by the identification of shared cis-regulatory elements

152 (CREs) driving the expression of genes common to both the ancestral and the novel trait

153 (eyespots). To identify putative CREs specific to wing tissue with eyespots, we used 154 Formaldehyde-Assisted Isolation of Regulatory Elements using sequencing (FAIRE-seq) to identify the open chromatin profile around $D l l$ in forewing and hindwing pupal tissues of $B$. anynana. We produced separate libraries from the proximal and distal regions of the wing. Mapping of FAIRE-seq reads from each wing region to a previously published $D l l$ BAC (scaffold length of $230 \mathrm{~kb}$ ) revealed 18 regions of open chromatin across this scaffold, representing candidate CREs (Fig. 3A). A BLAST search of each candidate CRE against the B. anynana genome revealed that most of these regions contained repetitive elements. However, one candidate CRE that was open in the distal forewing at scaffold position $150 \mathrm{~kb}$ (Fig. 3B) (Dll319 CRE), returned a unique BLAST hit to the genome. As this region did not contain any repetitive elements, we used CRISPR-Cas9 to disrupt its function. We designed four guide RNAs along its 319 bp length to maximize the likelihood of its disruption (Fig. 3A, Fig. S15). We obtained a variety of different phenotypes that were also observed when targeting exons of the $D l l$ gene using CRISPR (6): several caterpillars showed a missing or necrotic thoracic leg (Fig. 3C, Fig. S16), adults were missing legs and even a hindwing (Fig. 3D-E), adults lacked eyespots (Fig. 3F-H), adults showed truncated antennae, pigmentation defects, and loss of wing scales (Fig. 3I-J and Fig. S16-S19, Table S1), all having deletions within the CRE of various sizes (Fig. S16). These findings confirm that the Dll319 CRE is

171 pleiotropic and further suggest that eyespots use the same GRN as antennae in addition to legs 172 and wings. 
174 In order to confirm that the Dll319 contains a functional and pleiotropic CRE, we cloned a 917

175 bp region containing this CRE into a piggyBac-based reporter construct (22) and evaluated its

176 CRE activity in transgenic butterflies. We observed that embryos expressed the reporter gene

177 (EGFP) in antennae, mouthparts, as well as thoracic limbs, indicating that this CRE is sufficient

178 to drive gene expression both in antennae and legs (Fig. 3K and S20). Unfortunately, the loss

179 of this line precluded us from visualizing EGFP expression in eyespots. Using this same cloned

180 region containing the Dll319 CRE, we also observed pleiotropic CRE activity in antennae,

181 mouthparts, legs, and genitalia, when tested in a cross-species setting with Drosophila

182 melanogaster (Fig. S21), suggesting that this region contains an ancestral and pleiotropic CRE

183 present in the ancestors of flies and butterflies.

185 In order to investigate the extent to which other genes of the eyespot GRN share the same open-chromatin profiles as genes expressed in antennae and in other tissues, we performed an

Assay for Transposase-Accessible Chromatin using sequencing (ATAC-seq) with the same tissues used for the transcriptome analysis. A differential accessibility analysis for the openchromatin regions associated with the eyespot DE genes showed that eyespots shared the greatest number of open-chromatin regions with antennae, as compared to other tissues at the across all different stages and tissues, irrespective of the expression of $D l l$ (Fig. 4A), suggesting that pleiotropic CREs may always be open throughout development. To test this, we further targeted a genomic region of sal (sal740) that had open-chromatin across most developmental stages using CRISPR-Cas9 (Fig. 4B). We obtained aberrations in caterpillar horns, adult antennae, leg and chevron patterns, as well as missing eyespots and a missing wing (Fig. 4C-4F, Fig. S22), again confirming the presence of a pleiotropic CRE for a gene common to both eyespots and antennae. 
200 To further confirm that the two CREs (Dll319\& sal740) drive Dll and sal in an endogenous

201 context, we reanalyzed Hi-C data from the wandering larval stage, when Dll and Sal proteins

202 are expressed in eyespot centers (Fig. 2). Using the Dll319 and sal740 CREs as a bait, we

203 observed that these two sequences physically interact with the $\mathrm{Dll}$ promotor and sal promoter, respectively (Fig. S23).

205

By exploring the gene expression profile and functional regulatory connections of elements of

the eyespot GRN, we showed that eyespots, a morphological novelty in nymphalid butterflies, likely evolved via co-option of the antennal GRN, the oldest urbilaterian appendage. This network, initially deployed in primitive sensory systems, has been subsequently recruited and modified to produce legs (23) and perhaps even wings $(24,25)$. We show that the transcriptome

211 profile of eyespots more closely resembles that of antennae compared to any other tested appendage or butterfly tissue. Furthermore, genes known to be critical for eyespot development

213 share the same functional connections as observed in Drosophila antennae. Previous studies in Drosophila had demonstrated the same CRE driving reporter gene expression in separate traits, and CRE disruptions leading to pleiotropic effects on patterns of CRE activity (26). However, both ancestral and derived traits, which provides uncontroversial evidence for GRN co-option.

219 The cis-regulatory paradigm (27) suggests that, when a gene is expressed in a different developmental context, it uses a different CRE for its activation. Here we show that this does not apply to traits that emerge through gene-network co-option, as the recruited network genes are most likely sharing pre-existent regulatory connections $(26,28)$ (Fig. 4I). The origin of novelties has remained an important unanswered question in biology; and here we show that 
novelties can arise from GRN co-option, which provides a mechanism for complex traits to evolve rapidly from pre-existing traits.

\section{References}

231 1. W. J. Glassford, W. C. Johnson, N. R. Dall, S. J. Smith, Y. Liu, W. Boll, M. Noll, M. Rebeiz, Co-option of an Ancestral Hox-Regulated Network Underlies a Recently Evolved Morphological Novelty. Dev. Cell. 34, 520-531 (2015).

2. S. B. Carroll, J. Gates, D. N. Keys, S. W. Paddock, G. E. Panganiban, J. E. Selegue, J. a Williams, Pattern formation and eyespot determination in butterfly wings. Science. 265, 109-14 (1994).

3. S. V Saenko, V. French, P. M. Brakefield, P. Beldade, Conserved developmental processes and the formation of evolutionary novelties: examples from butterfly wings. Philos. Trans. R. Soc. Lond. B. Biol. Sci. 363, 1549-55 (2008).

4. L. I. Held, Rethinking Butterfly Eyespots. Evol. Biol. 40, 158-168 (2013).

5. A. Monteiro, G. Glaser, S. Stockslager, N. Glansdorp, D. Ramos, Comparative insights into questions of lepidopteran wing pattern homology. BMC Dev. Biol. 6, 1-13 (2006). Monteiro, Activation of butterfly eyespots by Distal-less is consistent with a reactiondiffusion process. Dev. 146, 1-12 (2019).

246 7. J. M. Musser, G. P. Wagner, Character trees from transcriptome data: Origin and individuation of morphological characters and the so-called "species signal." J. Exp. Zool. Part B Mol. Dev. Evol. 324, 588-604 (2015). for RNA-seq data with DESeq2. Genome Biol. 15, 1-21 (2014). 
251 9. R. Suzuki, H. Shimodaira, Pvclust: An R package for assessing the uncertainty in hierarchical clustering. Bioinformatics. 22, 1540-1542 (2006).

253

10. N. Özsu, A. Monteiro, Wound healing, calcium signaling, and other novel pathways are associated with the formation of butterfly eyespots. BMC Genomics. 18 (2017), doi:10.1186/s12864-017-4175-7.

11. J. D. Uhl, A. Zandvakili, B. Gebelein, A Hox Transcription Factor Collective Binds a Highly Conserved Distal-less cis-Regulatory Module to Generate Robust Transcriptional Outcomes. PLoS Genet. 12, 1-26 (2016).

12. J. T. Wagner-Bernholz, O. Wilson, G. Gibson, R. Schuh, W. J. Gehring, Identification of target genes of the homeotic gene Antennapedia by enhancer detection (Genes and Development 5 (2467-2480)). Genes Dev. 6, 328 (1992).

13. P. D. Si Dong, J. Chu, G. Panganiban, Coexpression of the homeobox genes Distalless and homothorax determines Drosophila antennal identity. Development. 127, 209$216(2000)$.

14. J. C. Oliver, X. L. Tong, L. F. Gall, W. H. Piel, A. Monteiro, A Single Origin for Nymphalid Butterfly Eyespots Followed by Widespread Loss of Associated Gene Expression. PLoS Genet. 8 (2012), doi:10.1371/journal.pgen.1002893.

15. Y. Matsuoka, A. Monteiro, Hox genes are essential for the development of novel serial homologous eyespots on the wings of Bicyclus anynana butterflies. Gentics, iyaa005 (2020).

16. T. Das Banerjee, A. Monteiro, Molecular mechanisms underlying simplification of venation patterns in holometabolous insects. Dev. dev.196394 (2020), doi:10.1242/dev.196394. 
doi:10.1038/ncomms11769.

277 18. C. R. Brunetti, J. E. Selegue, A. Monteiro, V. French, P. M. Brakefield, S. B. Carroll,

278

279

280

281

282

283

284 The generation and diversification of butterfly eyespot color patterns. Curr. Biol. 11, $1578-1585$ (2001).

19. S. V. Saenko, M. S. P. Marialva, P. Beldade, Involvement of the conserved Hox gene Antennapedia in the development and evolution of a novel trait. Evodevo. 2, 9 (2011).

20. G. Panganiban, Distal-less Function During Drosophila Appendage and Sense Organ Development. Dev. Dyn. 562, 554-562 (2000).

21. B. S. Emerald, S. M. Cohen, Spatial and temporal regulation of the homeotic selector gene Antennapedia is required for the establishment of leg identity in Drosophila. Dev. Biol. 267, 462-472 (2004).

22. Y. T. Lai, K. D. Deem, F. Borràs-Castells, N. Sambrani, H. Rudolf, K. Suryamohan, E. El-Sherif, M. S. Halfon, D. J. McKay, Y. Tomoyasu, Enhancer identification and activity evaluation in the red flour beetle, Tribolium castaneum. Dev. 145 (2018), doi:10.1242/dev.160663.

23. G. Panganiban, J. L. R. Rubenstein, Developmental functions of the Distal-less/Dlx homeobox genes. Development. 129, 4371-86 (2002).

24. H. S. Bruce, N. H. Patel, Knockout of crustacean leg patterning genes suggests that insect wings and body walls evolved from ancient leg segments (2020), vol. 4.

25. C. M. Clark-Hachtel, Y. Tomoyasu, Two sets of candidate crustacean wing homologues and their implication for the origin of insect wings. Nat. Ecol. Evol. 4, 1694-1702 (2020).

26. G. Sabarís, I. Laiker, E. Preger-Ben Noon, N. Frankel, Actors with Multiple Roles: Pleiotropic Enhancers and the Paradigm of Enhancer Modularity. Trends Genet. 35, 423-433 (2019). 
27. B. Prud'homme, N. Gompel, S. B. Carroll, Emerging principles of regulatory evolution. Light Evol. 1, 109-127 (2007).

28. A. Monteiro, O. Podlaha, Wings, horns, and butterfly eyespots: how do complex traits evolve? PLoS Biol. 7, e37 (2009).

29. H. Li, R. Durbin, Fast and accurate short read alignment with Burrows-Wheeler transform. Bioinformatics. 25, 1754-1760 (2009).

30. H. Li, B. Handsaker, A. Wysoker, T. Fennell, J. Ruan, N. Homer, G. Marth, G. Abecasis, R. Durbin, The Sequence Alignment/Map format and SAMtools. Bioinformatics. 25, 2078-2079 (2009).

31. A. R. Quinlan, I. M. Hall, BEDTools: A flexible suite of utilities for comparing genomic features. Bioinformatics. 26, 841-842 (2010).

32. Y. Zhang, T. Liu, C. A. Meyer, J. Eeckhoute, D. S. Johnson, B. E. Bernstein, C. ChIP-Seq (MACS). Genome Biol. 9 (2008), doi:10.1186/gb-2008-9-9-r137.

33. Y. Naito, K. Hino, H. Bono, K. Ui-Tei, CRISPRdirect: Software for designing CRISPR/Cas guide RNA with reduced off-target sites. Bioinformatics. 31, 1120-1123 (2015).

34. K. N. Eckermann, H. M. M. Ahmed, M. KaramiNejadRanjbar, S. Dippel, C. E. 
36. B. Bushnell, BBMap: A Fast, Accurate, Splice-Aware Aligner. United States N. $p$ (2014), (available at https://www.osti.gov/biblio/1241166-bbmap-fast-accurate-spliceaware-aligner).

37. E. Kopylova, L. Noé, H. Touzet, SortMeRNA: Fast and accurate filtering of ribosomal RNAs in metatranscriptomic data. Bioinformatics. 28, 3211-3217 (2012).

38. M. Pertea, D. Kim, G. M. Pertea, J. T. Leek, S. L. Salzberg, Transcript-level expression analysis of RNA-seq experiments with HISAT, StringTie and Ballgown. Nat. Protoc. 11, 1650-1667 (2016).

39. M. S. Campbel, C. Holt, B. Moore, M. Yandell, Genome Annotation and Curation Using MAKER and MAKER-P (2008), vol. 48.

40. B. J. Haas, A. Papanicolaou, M. Yassour, M. Grabherr, D. Philip, J. Bowden, M. B. Couger, D. Eccles, B. Li, M. D. Macmanes, M. Ott, J. Orvis, N. Pochet, F. Strozzi, N. Weeks, R. Westerman, T. William, C. N. Dewey, R. Henschel, R. D. Leduc, N. Friedman, A. Regev, De novo transcript sequence recostruction from RNA-Seq: reference generation and analysis with Trinity (2013), vol. 8.

41. C. R. Fisher, J. L. Wegrzyn, E. L. Jockusch, Co-option of wing-patterning genes underlies the evolution of the treehopper helmet. Nat. Ecol. Evol. 4, 250-260 (2020).

42. R Core Team, R: A language and environment for statistical computing (2020).

43. M. R. Corces, A. E. Trevino, E. G. Hamilton, P. G. Greenside, N. A. SinnottArmstrong, S. Vesuna, A. T. Satpathy, A. J. Rubin, K. S. Montine, B. Wu, A. Kathiria, S. W. Cho, M. R. Mumbach, A. C. Carter, M. Kasowski, L. A. Orloff, V. I. Risca, A. Kundaje, P. A. Khavari, T. J. Montine, W. J. Greenleaf, H. Y. Chang, An improved ATAC-seq protocol reduces background and enables interrogation of frozen tissues. Nat. Methods. 14, 959-962 (2017).

44. A. P. Boyle, J. Guinney, G. E. Crawford, T. S. Furey, F-Seq: A feature density 
estimator for high-throughput sequence tags. Bioinformatics. 24, 2537-2538 (2008).

352

353

45. Y. Liao, G. K. Smyth, W. Shi, FeatureCounts: An efficient general purpose program for assigning sequence reads to genomic features. Bioinformatics. 30, 923-930 (2014).

46. F. Ramírez, F. Dündar, S. Diehl, B. A. Grüning, T. Manke, DeepTools: A flexible platform for exploring deep-sequencing data. Nucleic Acids Res. 42, 187-191 (2014).

47. N. C. Durand, M. S. Shamim, I. Machol, S. S. P. Rao, M. H. Huntley, E. S. Lander, E. L. Aiden, A. Mathematics, Juicer provides a one-click system for analyzing loopresolution Hi-C experiments. Cell Syst. 3, 95-98 (2018).

48. J. Ray, P. R. Munn, A. Vihervaara, J. J. Lewis, A. Ozer, C. G. Danko, J. T. Lis, Chromatin conformation remains stable upon extensive transcriptional changes driven by heat shock. Proc. Natl. Acad. Sci. U. S. A. 116, 19431-19439 (2019).

49. R. W. Nowell, B. Elsworth, V. Oostra, B. J. Zwaan, C. W. Wheat, M. Saastamoinen, I. J. Saccheri, A. E. van’t Hof, B. R. Wasik, H. Connahs, M. L. Aslam, S. Kumar, R. J. Challis, A. Monteiro, P. M. Brakefield, M. Blaxter, A high-coverage draft genome of the mycalesine butterfly Bicyclus anynana. Gigascience. 6, 1-7 (2017).

50. P. Beldade, S. V. Saenko, N. Pul, A. D. Long, A gene-based linkage map for Bicyclus anynana butterflies allows for a comprehensive analysis of synteny with the lepidopteran reference genome. PLoS Genet. 5 (2009), doi:10.1371/journal.pgen.1000366.

51. J. Catchen, A. Amores, S. Bassham, G3\&amp;\#58; Genes $\mid$ Genomes $\mid$ Genetics, in press, doi:10.1534/g3.120.401485.

52. F. A. Simão, R. M. Waterhouse, P. Ioannidis, E. V. Kriventseva, E. M. Zdobnov, BUSCO: Assessing genome assembly and annotation completeness with single-copy orthologs. Bioinformatics. 31, 3210-3212 (2015).

53. P. Jones, D. Binns, H. Y. Chang, M. Fraser, W. Li, C. McAnulla, H. McWilliam, J. 
Maslen, A. Mitchell, G. Nuka, S. Pesseat, A. F. Quinn, A. Sangrador-Vegas, M. Scheremetjew, S. Y. Yong, R. Lopez, S. Hunter, InterProScan 5: Genome-scale protein function classification. Bioinformatics. 30, 1236-1240 (2014).

54. J. Dainat, AGAT: Another Gff Analysis Toolkit to handle annotations in any GTF/GFF format.(Version v0.4.0) (2020), doi:10.5281/ZENODO.4205393.

55. B. Buchfink, C. Xie, D. H. Huson, Fast and sensitive protein alignment using DIAMOND. Nat. Methods. 12, 59-60 (2014).

56. S. Götz, J. M. García-Gómez, J. Terol, T. D. Williams, S. H. Nagaraj, M. J. Nueda, M. Robles, M. Talón, J. Dopazo, A. Conesa, High-throughput functional annotation and data mining with the Blast2GO suite. Nucleic Acids Res. 36, 3420-3435 (2008).

\section{Acknowledgement:}

We would like to thank NUS HPC for allowing access to perform the bioinformatic analysis. Tirtha Das Banerjee for his comments on manuscript.

\section{Funding:}

This work was supported by the Ministry of Education, Singapore award MOE2015-T2-2-159 and the National Research Foundation, Singapore NRF Investigatorship award NRF-NRFI052019-0006 and NRF-CRP20-2017-0001 to AM. SNM was supported by a Yale-NUS Scholarship. YT is thankful to the National Science Foundation (NSF) (grant IOS1557936) and the U.S. Department of Agriculture (USDA) (grant 2018- 08230).

\section{Authors contribution:}


400 SNM, HC, YM, and AM designed and conceived the project. SNM, HC, YM, MDG, MH,

$401 \mathrm{GV}, \mathrm{SM}, \mathrm{KDD}$ performed the experiments. TW and YT critically revised and, SNM, HC,

402 YM, AM analyzed the data and wrote the manuscript.

403

404 Competing interests:

405 Authors declare that they have no competing interests

406

407 Data Availability:

408 All raw Illumina reads of RNA-seq, ATAC-seq and Hi-C are available under NCBI

409 Bioproject (PRJNA685019)

410

411

412

413 
A embryos

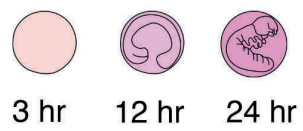

B

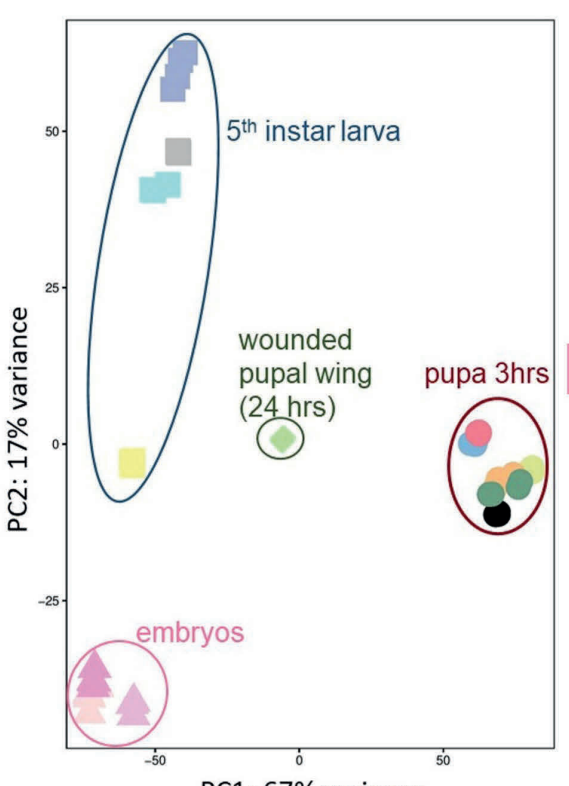

5th instar larva

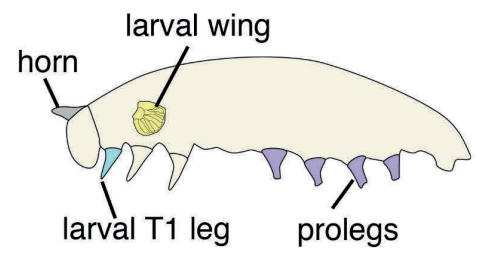

C pupa 3hrs

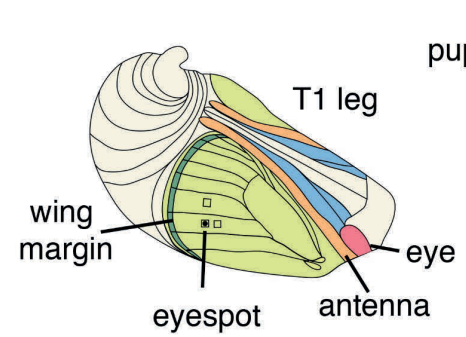

pupal wing (24 hrs)

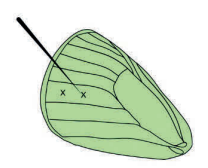

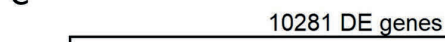
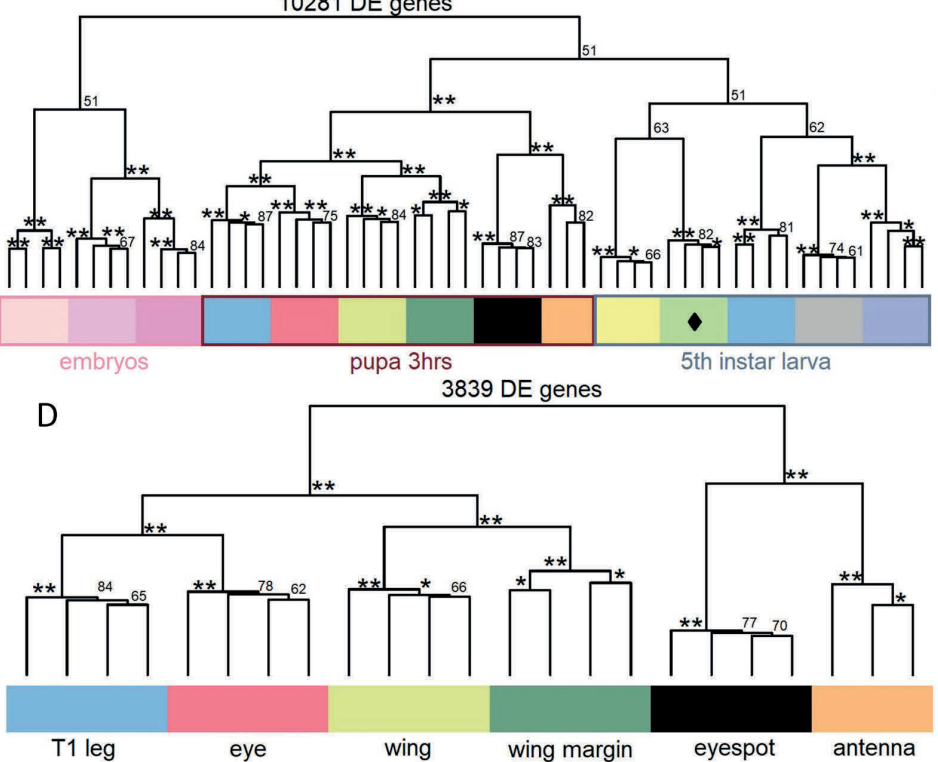

415

Fig. 1: Tissues used for RNA-seq analysis and character tree constructed using the

differentially expressed (DE) genes. (A). We used 16 tissue groups from three separate

418 developmental stages of $B$ anynana for RNA extractions. Embryos at $3 \mathrm{hrs}, 12 \mathrm{hrs}$ and $24 \mathrm{hrs}$

419 after egg laying. Larval forewings, T1-legs, horns and prolegs. Pupal antenna, T1-leg,

420 forewing, eye, wing margin, eyespot, and two eyespot control tissues all dissected at $3 \mathrm{hrs}$ after

421 pupation, and a wounded wing dissected at 24hrs after pupation. (B). PCA using $10281 \mathrm{DE}$

422 genes obtained from pairwise comparisons between different tissues. Tissues are clustering

423 according to their developmental stages. (C). Character tree constructed using $10281 \mathrm{DE}$ genes

424 showing eyespot tissue clustering with antenna tissue first, and next with tissues from same

425 developmental stage, except for a $24 \mathrm{hrs}$ wounded wing ( $)$, which clustered with larval wing

426 tissue (D). Character tree constructed using 3839 DE genes from $3 \mathrm{hr}$ pupal stage showing 
bioRxiv preprint doi: https://doi.org/10.1101/2021.03.01.429915; this version posted March 1,2021. The copyright holder for this preprint

(which was not certified by peer review) is the author/funder, who has granted bioRxiv a license to display the preprint in perpetuity. It is made available under aCC-BY 4.0 International license.

427 eyespot tissue clusters with antenna tissue, which together form an outgroup to the rest of the

428 samples. **- 100 unbiased (AU) p-value; *- 90-99 unbiased (AU) p-value; $\bullet$ - wounded pupal

429 wing $(24 \mathrm{hrs})$

430

431

432

433

434

435

436

437

438

439

440 

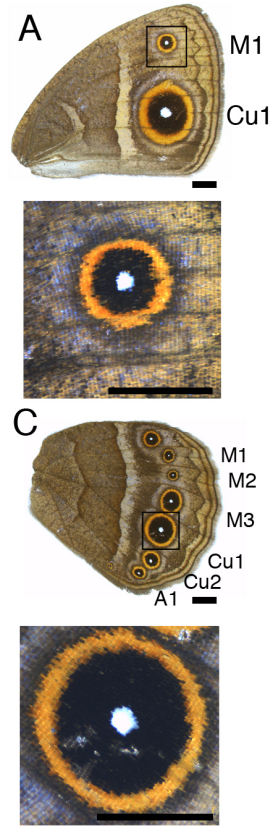

$\mathrm{N}$

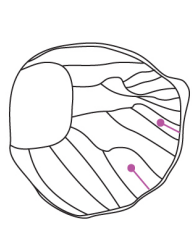

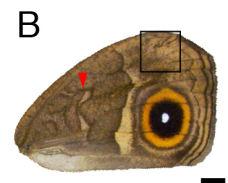
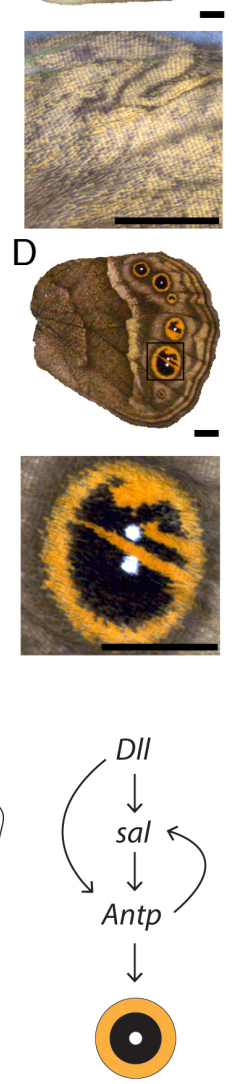
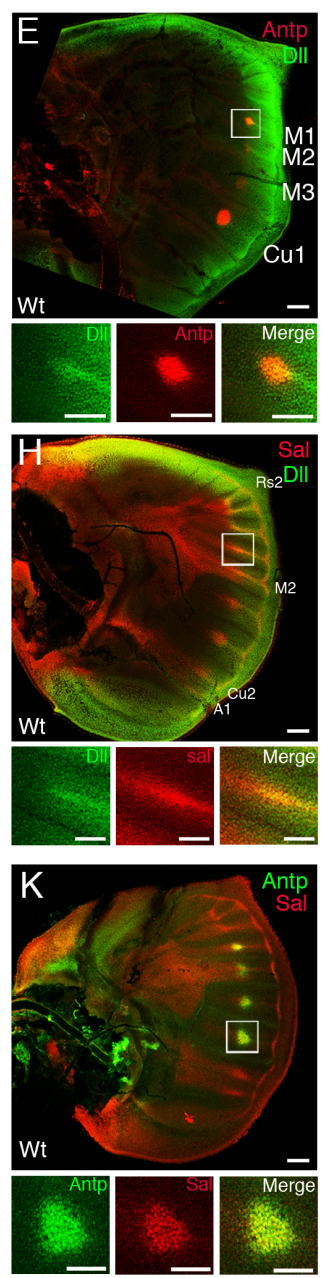
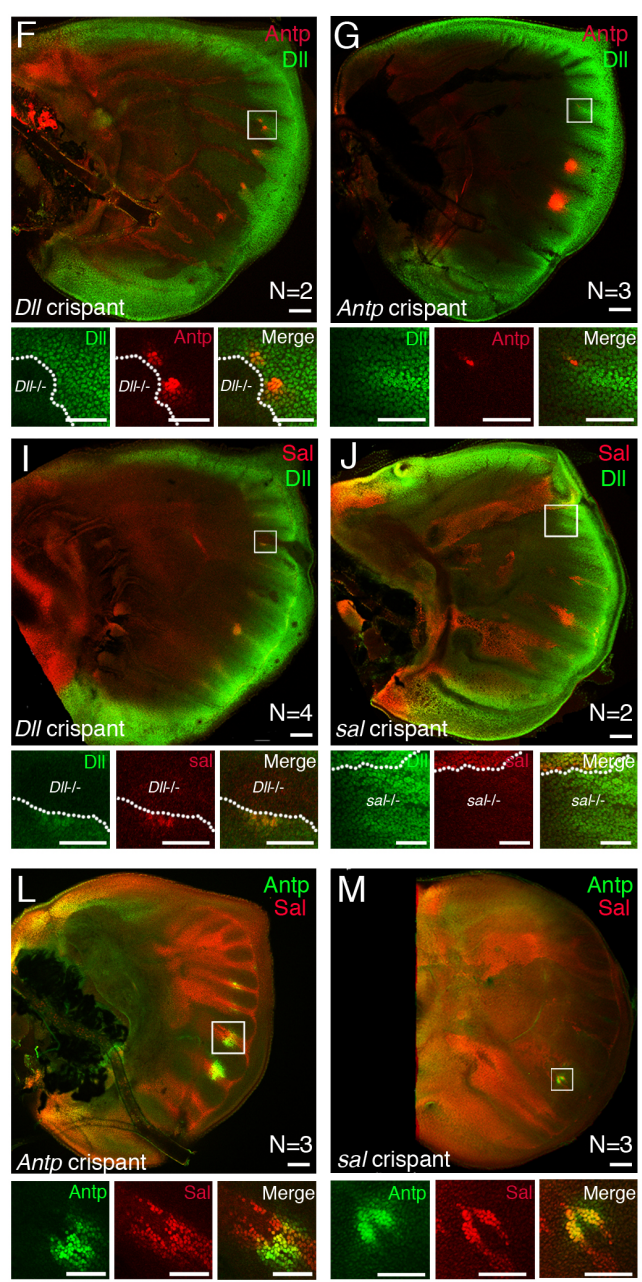

forewing (C) Wt female hindwing. (D) sal crispant female hindwing (E) Expression pattern of

448 Dll and Antp proteins in Wt forewing. (F) Expression pattern of Dll and Antp proteins in Dll

449 crispant forewing. (G) Expression pattern of Dll and Antp proteins in an Antp crispant forewing.

450 (H) Expression pattern of D1l and Sal proteins in Wt forewing. (I) Expression pattern of Dll and

451 Sal proteins in Dll crispant forewing. (J) Expression pattern of Dll and Sal proteins in sal 452 crispant forewing. (K) Expression pattern of Sal and Antp proteins in Wt forewing. (L) 
453 Expression pattern of Sal and Antp proteins in Antp crispant forewing. (M) Expression pattern

454 of Sal and Antp proteins in sal crispant forewing. White square regions were highly magnified.

455 (N) Schematic diagram of genetic interaction among Dll, sal, and Antp in the eyespot region of

456 a developing forewing. Scale bars in A-D: $5 \mathrm{~mm}$ for whole wings and wing details. Scale bars

457 in E-M: $100 \mu \mathrm{m}$ in low and $50 \mu \mathrm{m}$, in high magnification

458

459

460

461

462

463

464

465

466

467

468

469 

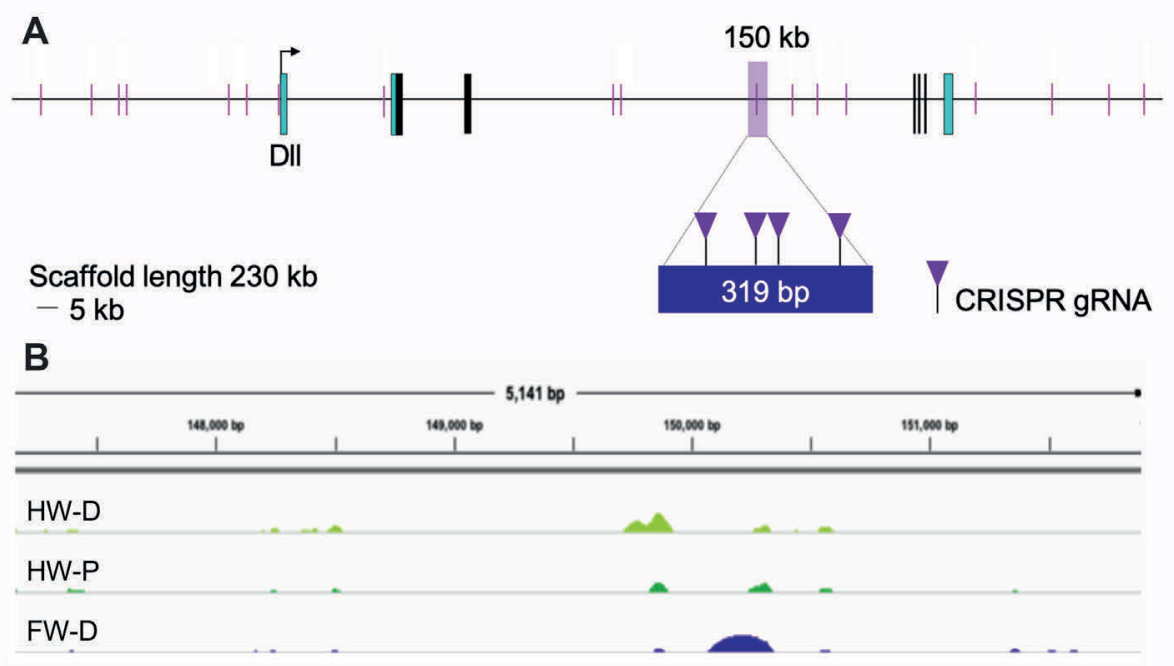

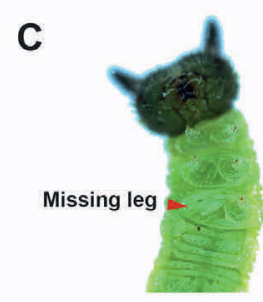

$\mathbf{F}$

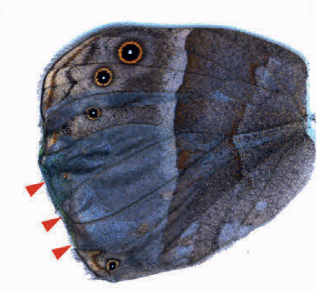

I

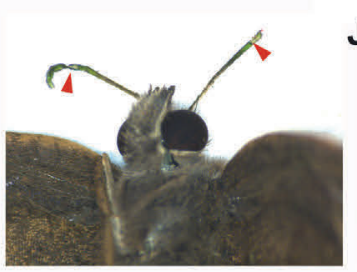

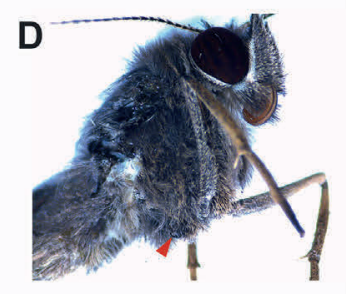

Missing leg

G

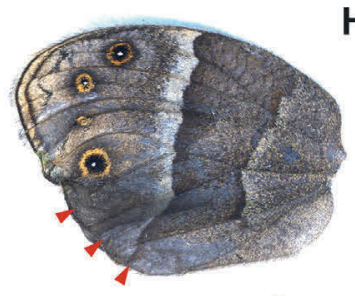

J

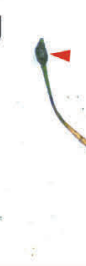

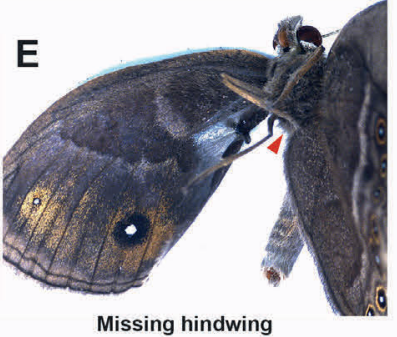

H

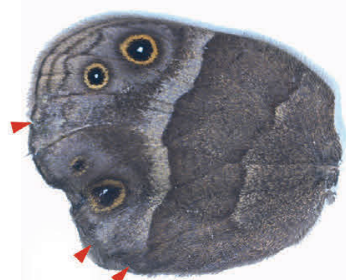

K

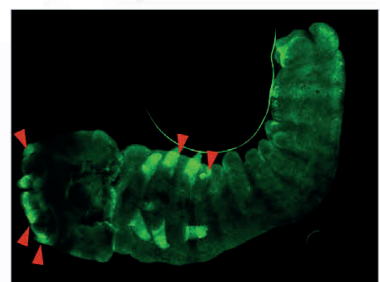

473 Fig. 3. Multiple traits are affected by disruptions of a single Distal-less CRE. (A) $B$.

475 regions at 24 hours post-pupation (short red lines). First exon (UTR in blue) shows open

476 chromatin region (highlighted by a short red line) at position $54 \mathrm{~kb}$ at the transcriptional start site of Distal-less. The CRE at position $150 \mathrm{~kb}$ (Dll319; highlighted with a pink bar) is open in 
478 B. anynana forewing and was targeted with CRISPR. Four RNA guides were used

479 simultaneously to target this region. (B) FAIRE-seq results showing an open region of 480 chromatin in the distal forewing (FW-D) at position $150 \mathrm{~kb}$ on the Distal-less BAC (blue peak).

481 (C-E) crispant phenotypes from the same individual: with a missing thoracic leg as a caterpillar,

482 and same missing thoracic leg and also missing hindwing as an adult. (F-H) Crispant wing

483 phenotypes showing loss of eyespots and pigmentation defects. (I-J) Crispants showing

484 antennal defects (K) Transgenic embryo showing EGFP expression driven by the Dll319 CRE

485 in mouthparts, antennae, legs, and pleuropodia (red arrows from left to right). 
bioRxiv preprint doi: https://doi.org/10.1101/2021.03.01.429915; this version posted March 1, 2021. The copyright holder for this preprint (which was not certified by peer review) is the author/funder, who has granted bioRxiv a license to display the preprint in perpetuity. It is made available under aCC-BY 4.0 International license.
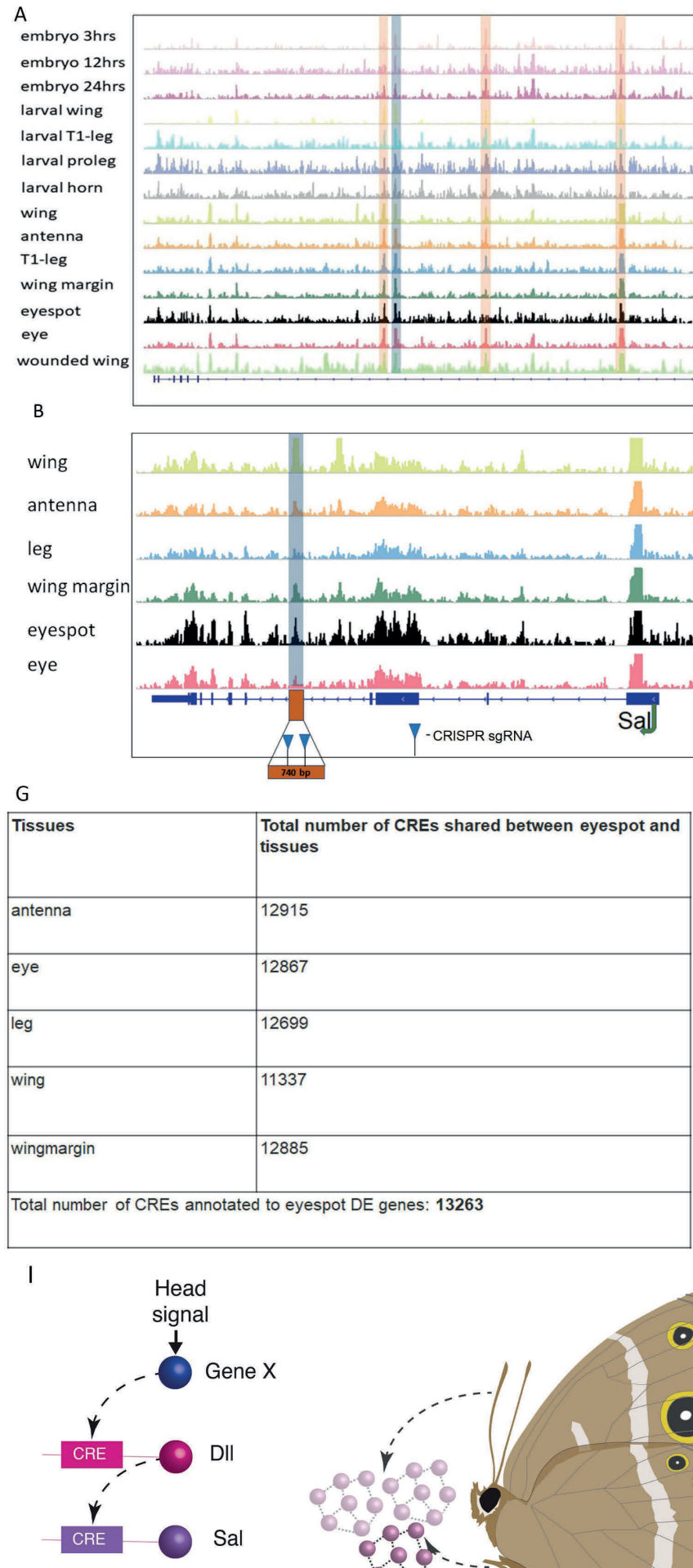

Antenna network

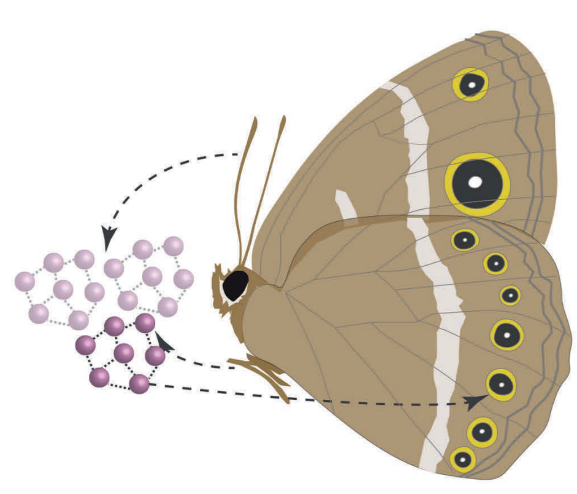

$\mathrm{H}$

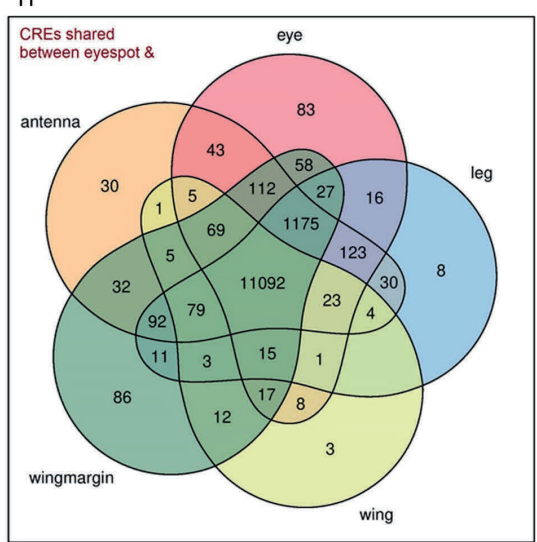

C

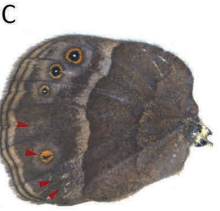

E
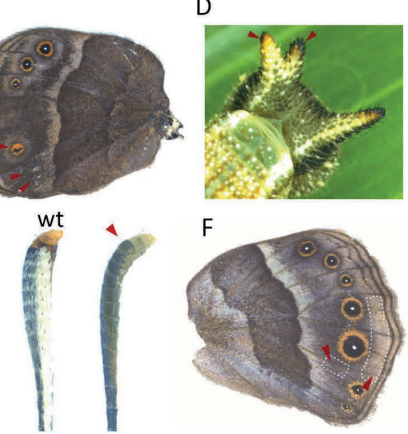

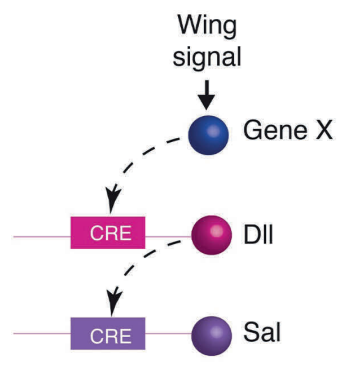

Eyespot network 
494 the targeted Dll319 (blue). (B). ATAC peak regions from $3 \mathrm{hr}$ pupal tissues around the sal

495 genomic region with the CRE (sal740) targeted highlighted in blue. (C-F). sal740 crispant phenotypes: Missing and reduced eyespots (C), split horn (D), thinner and discolored antenna compared to wild type (E), lost chevrons in the wing margin and ectopic vein in the $\mathrm{Cu} 2$ sector (F). (G). Table with the total number of open peaks associated with eyespot DE genes and number of peaks shared between eyespots and different tissues. $(\mathrm{H})$. Venn diagram showing

500 the number of open chromatin regions shared between different tissue groups. (I). Schematic

501 illustrating the hypothesis that eyespots evolved via co-option of an antennal GRN with genes 
521 Suriya Narayanan Murugesan ${ }^{1, *}+\uparrow$, Heidi Connahs ${ }^{1, *}, \dagger$, Yuji Matsuoka ${ }^{1,} \uparrow$, Mainak das Gupta ${ }^{1}$, 522 Manizah Huq ${ }^{1}, \mathrm{~V}_{\text {Gowri }}{ }^{1}$, Sarah Monroe ${ }^{1}$, Kevin D. Deem ${ }^{2}$, Thomas Werner ${ }^{3}$, Yoshinori 523 Tomoyasu $^{2}$, Antónia Monteiro ${ }^{1,4, *}$ 
Materials and Methods

\section{Butterfly husbandry}

558 Bicyclus anynana were maintained in lab populations and reared at $27^{\circ} \mathrm{C}$ and $60 \%$ humidity inside a climate room with 12:12 h light:dark cycle. All larvae were supplied with young corn leaves to complete their development until pupation. Following pupation, the pupae were collected and placed in a separate cage until they emerged. The butterflies were fed every other day with banana on moist cotton in Petri dishes.

563

\section{Wing library preparation and FAIRE-seq analysis}

565 Wings were dissected from $B$. anynana at $\sim 22-26$ hours post-pupation. For control input libraries (non-enriched), 2 whole forewings and 2 whole hindwings were pooled. Three FAIRE-enriched libraries were prepared in total, including a forewing distal library (the pupal wing was cut in half and the distal region was used for the library) and 2 hindwing libraries, using both the proximal and distal regions of the wing. All FAIRE-enriched libraries were prepared from 7-8 pooled wing tissues. Libraries were prepared by Genotypic Technology (India) as 75bp pair-end reads and sequenced, using Illumina NextSeq. Raw reads were qualitychecked and reads with phred scores $>30$ were retained for downstream analyses. Following the removal of adapters and low-quality bases, the reads were aligned to a $B$. anynana BAC sequence containing $\mathrm{Dll}$, with BWA (0.7.13)(29), using the following parameters: $-\mathrm{k}$ INT, -W INT, -A INT, -B INT, -O INT, -E INT, -L INT, -U INT. The resulting SAM files were converted to BAM files, using SAMtools-0.1.7a(30). The BAM files were converted to sorted BAM, followed by removal of PCR duplicates. The final BAM files were converted to BEDgraph files, using BEDtools-2.14.3(31). Peaks were called with MACS2 software(32), using the aligned enriched and input (control) files with the q-value (minimum FDR) cutoff to call significant regions. The command bdgcmp script was used on the enriched and input BEDgraph files to generate fold-enrichment and log likelihood scores. This command also removed noise from the enriched sample relative to the control. The BEDgraph files were converted to BigWig files for visualization in Integrative genomic viewer (IGV).

\section{Identifying cis-regulatory elements (CREs) for CRISPR-Cas9 experiments}

The FAIRE-seq data were visualized using IGV. All 18 candidate CREs identified around the Dll locus were blasted against the $B$. anynana genome in LepBase to verify whether they were unique in the genome. Most of the candidate CREs were not unique and had multiple hits throughout the genome. One of the unique regions, the CRE Dll319, was selected as a suitable target for CRISPR knock-out.

\section{Single guide RNA design and production}

Single guide RNA (sgRNA) target sequences for sal were selected based on their GC content (around 60\%) and the number of mismatch sequences relative to other sequences in the genome ( $>3$ sites). In addition, we selected target sequences that started with a guanidine for subsequent in vitro transcription by T7 RNA polymerase. sgRNA for the Dll319 CRE were designed using 
region (Fig. S24, and Table S2). The sgRNA templates were created by a PCR reaction with overlapping primers, using Q5 polymerase (New England Biolabs). Constructs were transcribed using T7 polymerase and (10X) transcription buffer (New England Biolabs), RNAse inhibitor (Ribolock), NTPs $(10 \mathrm{mM})$ and $600 \mathrm{ng}$ of the PCR template. The final sample volume was $40 \mu \mathrm{L}$. Samples were incubated for $16 \mathrm{~h}$ at $37^{\circ} \mathrm{C}$ and then treated with $2 \mu \mathrm{L}$ of DNAse 1 at $37^{\circ} \mathrm{C}$ for 15 minutes. Samples were purified by ethanol precipitation, and RNA size and integrity were confirmed by gel electrophoresis.

\section{Cas9 mRNA production}

The plasmid pT3TS-nCas9n (Addgene) was linearized with XbaI (NEB) and purified by phenol/chloroform purification and ethanol precipitation. pT3TS-nCas9n was a gift from Wenbiao Chen (Addgene plasmid \# 46757; http://n2t.net/addgene:46757; RRID:Addgene_46757). In vitro transcription of mRNA was performed using the mMESSAGE mMACHINE T3 kit (Ambion). One microgram of linearized plasmid was used as a template, and a poly(A) tail was added to the synthesized mRNA by using the Poly(A) Tailing Kit (Thermo Fisher). The A-tailed RNA was purified by lithium-chloride precipitation and then dissolved in RNase-free water and stored at $-80^{\circ} \mathrm{C}$. The $\operatorname{Cas} 9$ transcript was used for producing sal crispants, and for the analysis of regulatory interactions among Dll, Antp, and sal.

\section{In vitro cleavage assay for the Dll319 CRE}

The sgRNAs were tested using an in vitro cleavage assay. Wild-type genomic DNA was amplified using primers that were at least $200 \mathrm{bp}$ from the sgRNA sites. sgRNA $(200 \mathrm{ng} / \mu \mathrm{L}$ per guide), Cas 9 protein $(800 \mathrm{ng} / \mu \mathrm{L}$ ) (stored in a buffer containing $300 \mathrm{mM} \mathrm{NaCl}, 0.1 \mathrm{mM}$ EDTA, $1 \mathrm{mM}$ DTT, $10 \mathrm{mM}$ Tris-HCl, 50\% glycerol $\mathrm{pH} 7.4$ at $\left.25^{\circ} \mathrm{C}\right)$, NEB buffer $3(1 \mu \mathrm{L})$ and BSA $(1 \mu \mathrm{L})$ were brought to a final volume of $10 \mu \mathrm{L}$ with nuclease-free water and incubated at $37^{\circ} \mathrm{C}$. After 15 minutes of incubation, the purified amplicon (100 ng) was added to the sample, which was then incubated for an additional $1-2 \mathrm{~h}$ at $37^{\circ} \mathrm{C}$. The entire reaction volume was analyzed on a 1\%-agarose gel. Cas9 protein was purchased from NEB EnGen Cas9 NLS. The cleavage assay confirmed that each guide successfully cleaved the PCR amplicon.

\section{Embryo injections}

Wild-type lab populations of $B$. anynana adults were provided with corn plants to lay eggs. The eggs were collected within $1.5 \mathrm{~h}$ of oviposition and placed onto 1 -mm-wide strips of double-sided tape in plastic Petri dishes $(90 \mathrm{~mm}$ ). Cas9 protein (final concentration $800 \mathrm{ng} / \mu \mathrm{L}$ ) and sgRNA (final concentration $200 \mathrm{ng} / \mu \mathrm{L}$ per guide) for all 4 guides were prepared in a total volume of $10 \mu \mathrm{L}$ and incubated for $15 \mathrm{~min}$ at $37^{\circ} \mathrm{C}$ prior to injection along with $0.5 \mu \mathrm{L}$ of food dye to improve visualization of the injected sample into the embryos. For sal crispants, Cas 9 mRNA $(500 \mu \mathrm{g} / \mu \mathrm{L}$ final concentration) and sgRNA $(500 \mu \mathrm{g} / \mu \mathrm{L}$ final concentration) were injected along with one tenth of the volume of food dye. For sal740 CRE, eggs were injected with the mix of Cas 9 protein (final concentration $800 \mathrm{ng} / \mu \mathrm{L}$ ) and sgRNA (final concentration $400 \mathrm{ng} / \mu \mathrm{L}$ per guide). The injection mixture was kept on ice after the incubation and prior to injection. Embryo injections were carried out by nitrogen-driven injections through glass capillary needles. Injected eggs were stored in closed Petri dishes containing cotton balls that 
643

644

645

646

647

648

649

650

651

652

653

654

655

656

657

658

659

660

661

662

663

664

665

666

667

668

669

670

671

672

673

674

675

676

677

678

679

680

681

682

683

684

685

686

were dampened daily to maintain humidity. The hatched larvae were reared in small paper cups for 1 week and then moved to corn plants to complete their development. Tables S1, S3 and S4 summarize the injection results.

\section{In vivo cleavage assay and genotyping of sal crispants}

Genomic DNA was extracted with a SDS-based method from a pool of 5 injected embryos that did not hatch. About 250 bp of sequence spanning the target sequence was amplified with PCRBIO Taq Mix Red (PCRBIOSYSTEMS), and PCR conditions were optimized until there were no smears, primer dimers, or extra bands. Primers are listed in Table S2. The PCR products were purified with the Gene JET PCR purification kit (Thermo Fisher). Two hundred nanograms of PCR product were denatured and re-annealed in 10x NEB2 buffer. One microliter of T7 endonuclease I (NEB) was added to the sample, while $1 \mu \mathrm{L}$ of MQ water was added to a negative control. Immediately after the incubation for $15 \mathrm{~min}$ at $37^{\circ} \mathrm{C}$, all the reactions were analyzed on a 3\% agarose gel. Amplicons that showed positive cleavage from the $\mathrm{T} 7$ endonuclease I assay were subcloned into the pGEM-Teasy vector (Promega) through TA cloning. For each target, we picked 8 colonies, extracted the plasmid with a traditional alkali-SDS method, and performed a Polyethylene glycol (PEG) precipitation. Sequence analysis was performed with the BIGDYE terminator kit and a 3730xl DNA Analyzer (Thermo Fisher).

\section{Screening and genotyping Dll319 crispants}

Newly emerged caterpillars were screened under a microscope to look for developmental defects affecting any regions where $D l l$ is expressed, such as the thoracic legs, mouthparts, and prolegs. Any caterpillars exhibiting defects were imaged and reared individually in paper cups until the butterflies eclosed. Caterpillars that died were immediately frozen for DNA isolation and genotyping. All other surviving caterpillars with no apparent developmental abnormalities were reared in groups on corn plants and fed ad-libitum every 2 days until pupation. The eclosed butterflies were frozen individually at $-20^{\circ} \mathrm{C}$. Each butterfly was carefully screened under a microscope and examined for asymmetric crispant phenotypes, focusing particularly on phenotypes expected for a $D l l$ knock-out, such as appendage, eyespot, or pigmentation defects.

\section{Colony PCR to identify CRE deletions}

For selected crispants, genomic DNA was extracted from the thorax (E.Z.N.A tissue DNA kit) and used for PCR to prepare samples for genotyping. The samples were visualized on a gel to confirm the correct size band and the PCR product was purified using a Thermo Scientific PCR purification kit. The DNA was cloned into a pGEM T-Easy Vector (Promega) and the plasmid was transformed into DH5 alpha E. coli. White colony selection was used for colony PCR. The bands were visualized on a $1 \%$-agarose gel to look for bands with shifts relative to the WT band. PCR products from colonies showing evidence of a deletion were submitted for Sanger sequencing PCR (Axil Scientific, Singapore), including a sample that was amplified from $B$. anynana wild-type genomic DNA.

\section{Butterfly enhancer reporter assay}


A 917 bp region containing the Dll319 CRE was cloned into the piggyGUE vector via the GATEWAY technology (Thermo Fisher). piggyGUE is the EGFP version of piggyGUM, the piggyBac-based reporter construct that was previously published(22). The details of piggyGUE will be published elsewhere (Deem and Tomoyasu, unpublished). The 917 bp region was amplified from $B$. anynana wild-type genomic DNA using a primer containing CACC at the 5 ' end for directional cloning. The PCR product was cloned into the pENTR vector and further cloned into the piggyGUE vector via a LR reaction, as described by Lai et al., 2018(22). Four microliters of the LR reaction mix were used for bacterial transformation. After sequence analysis to confirm the presence of SNPs in the Dll319 CRE, plasmid DNA was amplified, using a Midiprep kit (Qiagen). The piggyGUE Dll319 CRE plasmid was diluted to $1 \mu \mathrm{g} / \mu \mathrm{L}$ and mixed in a 1:1 ratio with a hyperactive piggyBac transposase plasmid(34). Embryos $(\mathrm{n}=550)$ were collected from $B$. anynana butterflies reared at $27^{\circ} \mathrm{C}$ and were injected $\sim 1$-hour after egg laying with the plasmid solution and a small amount of food dye, using a glass injection needle and nitrogen gas pressure. Eggs were transferred in a Petri dish to a chamber and kept moist to prevent dehydration. From this batch of eggs, 40 caterpillars hatched and were reared in paper cups during the first week and then transferred to cages with corn plants to complete their development. At all stages, caterpillars were fed corn ad-libitum. From this batch of caterpillars, 19 reached adulthood (10 females and 9 males). These butterflies were evenly distributed into 4 cages $(\sim 5 /$ cage) and placed with respective wild-type males and females for breeding. We were unable to observe any $d s$ Red signal (the positive marker of transgenesis driven by the $3 \mathrm{xP} 3$ promoter) in the eyes of the caterpillars from the F1 or F2 generation, despite ubiquitous $d s R e d$ signal in some $1^{\text {st }}$-intar larvae (only) of the F1 generation, which were used later for outcrossing to wild-type individuals. This ubiquitous signal was not observed again in the offspring of these larvae. We collected eggs from the F3 generation and dissected some embryos for EGFP antibody staining. Two out of the four dissected embryos did show expression of EGFP driven by the Dll319 CRE in the embryonic antennae, mouthparts, thoracic legs and pleuropodia (Fig. 3K, Fig. S10). Subsequent hemolymph PCR genetic screening in individuals of the $4^{\text {th }}$ generation failed to identify additional positive individuals and the line was lost.

718 The same 917 bp sequence that contained The Dll319 CRE was directionally cloned into 719 pENTR-D, then GATEWAY cloned into the piggyPhiGUGd, the Gal4-delta version of the previously reported piggyBac-based reporter construct(22). piggyPhiGUGd also has an attB site, allowing phiC31 transgenesis. The detail of piggyPhiGUE will be published elsewhere (Deem and Tomoyasu, unpublished). For Drosophila transgenesis, the piggyPhiGUGd Dll319 CRE construct was transformed into the attP2 site (68A4) through phiC31 integrase-mediated transgenesis system with EGFP as a visible marker (BestGene Drosophila transgenic service). Established transgenic flies were crossed with G-TRACE(35) to visualize the tissues with CRE activities. PBS buffer under the microscope. The samples were fixed in $4 \%$ formaldehyde/Fix buffer $(0.1$ 

The samples were washed with $0.02 \%$ PBSTx (PBS + Triton x-100) 3 times every $10 \mathrm{~min}$, and then blocked in 5\% BSA/PBSTx for $1 \mathrm{~h}$. The samples were then incubated in 5\% BSA/PBSTx with the primary antibody, and incubated at $4{ }^{\circ} \mathrm{C}$ overnight. As primary antibodies, we used a rabbit polyclonal anti-Dll antibody (at 1:200, a gift from Grace Boekhoff-Falk), a mouse monoclonal anti-Antp 4C3 antibody (at 1:200; Developmental Studies Hybridoma Bank), a rabbit anti-Sal antibody (at 1:20,000 for wings and pupal tissues, and 1:2,000 for embryos; de Celis et al., 1999), and a rabbit anti-EGFP antibody (at 1:200; Abcam ab290) for the transgenic embryos at $24 \mathrm{~h}(\mathrm{n}=4)$ and wt controls. For double staining, we added two primary antibodies to the same tube. The wings were washed with PBSTx 3 times every $10 \mathrm{~min}$. Then, we replaced the PBSTx with 5\% BSA/PBSTx to block for 1 hour, followed by the incubation with the secondary antibody $(1: 200)$ in $5 \%$ BSA/PBSTx at $4{ }^{\circ} \mathrm{C}$ for $2 \mathrm{~h}$. The wings were washed with PBSTx 3 times every $10 \mathrm{~min}$, followed by mounting the wings in ProLong Gold Antifade Mountant (Thermo Fisher). The images were taken under an Olympus FV3000 Confocal Laser Scanning Microscope.

\section{Sample collection and library preparation for RNA sequencing}

In order to identify gene expression patterns specific to eyespot formation on the developing wings, we extracted RNA from sixteen different tissue types at four developmental time points: 3-4-hour-old, 12-13-hour-old, and 24-25-hour-old embryos; T1 legs, prolegs, forewings, and horns from wandering caterpillars; T1 legs, antennae, forewings, forewing margins, eyes, eyespots, and two control tissues adjacent to eyespot centers from 3-h-old pupae (Fig. 1A). For wing wounding experiments, we poked one wing between 17 to $18 \mathrm{~h}$ after pupation in two different places in the M3 sector, using a fine tungsten needle with a diameter of $0.25 \mathrm{~mm}$ and $0.001 \mathrm{~mm}$ at the tip (FST-10130-10). We collected the wings 6 hours later, which corresponds to 23-24 h after pupation (Monteiro et al 2006). We performed the experiments with four biological replicates for each tissue type with 10 to 25 female individuals in each replicate (both left and right tissues were used, except for the wounded pupal wings, where a single wing was used) (Table S5). Total RNA was extracted in $70 \mu \mathrm{L}$ of nuclease-free water, using Qiagen RNA Plus Mini Kit. RNA quantity and integrity were measured using a Nanodrop and an RNA Bleach gel (Aranda et al 2013). RNA libraries were prepared, using the Truseq stranded mRNA kit from Illumina. Forty million reads were sequenced for each replicate, using Novoseq 6000 with $150 \mathrm{bp}$ paired-end and an average insert size of 250-300 bp. Library preparation and sequencing were carried out at AIT Novogene, Singapore. In order to avoid batch effects, we randomized the sample extraction and RNA isolation, such that two replicates of the same group were never extracted at same time.

\section{RNA-seq analysis}

The raw RNA-seq data were quality-controlled and filtered. Adapter sequences and reads with low quality (less than Q30) were trimmed, using bbduk scripts ( $\mathrm{ktrim}=\mathrm{r}, \mathrm{k}=23$, mink=11, hdist $=1$, tpe, tbo, qtrim $=\mathrm{rl}$, trimq $=30$, minlen=40). In order to remove any bacterial contamination in the samples, we used the bbsplit script, which is a part of the bbmap tools (36). All bacterial genomes were downloaded from NCBI (last downloaded in June 2018), and the reads were mapped to the bacterial genomes, using bbmap. Only reads whose pairs also 
passed through the filter were further analyzed. To remove any ribosomal RNA sequences from the RNA-seq data, the reads were aligned to the eukaryotic rRNA database available in sortmeRNA (37). The processed reads from different samples were then mapped to the BaGv2 genome, using hisat2 (38) (mapping statistics in Table S6), resulting in bam files that were sorted by genomic positions, using samtools (30). They were used as inputs in StringTie (38) to create the initial transcriptome assembly with 71,042 transcripts, which was used to annotate the genome using Maker v.3 (39), resulting in 18,196 genes with 29,389 transcripts.

\section{RNA-seq differentially expressed (DE) gene analysis}

A read count matrix of the annotated genes was obtained for the samples using StringTie (38). We used the GO terms to filter out any ribosomal genes before obtaining the read counts. This approach led to the removal of 496 genes to a final set of 17,700 genes, which was used throughout the analysis. Correlations between the replicate samples was analyzed using DESeq2 (8) with a sample distance matrix. One of the antennal samples was removed due to its poor correlation with its other biological replicates. The remaining samples were used for the downstream analyses (Fig. S25).

\section{Identifying eyespot-specific DE genes}

793

To identify eyespot-specific genes, a pairwise DE analysis was performed between eyespot and control adjacent tissues, Nes1 and Nes2, using DESeq2 (Fig. 1A, Fig. S2). Common genes upregulated and downregulated between eyespot vs. Nes1 and eyespot vs. Nes2 with an adjusted P-value (padj) of 0.05 were chosen as eyespot-specific DE genes (Spreadsheet S1).

\section{RNA hierarchical sample clustering}

799 In order to identify the tissue with the closest gene expression profile to eyespot, we used all tissue samples except the eyespot control tissue samples. DE analysis between the multiple tissues was performed, using run_DE_analysis.pl script provided in Trinity tool, using DESeq2 as the method of choice for this analysis (40). Hierarchical clustering was performed for the different tissues, using genes that showed a $\log 2$ fold change of $|2|$ and padj value of 0.001, as in Fisher et al (2020) (41). Clustering was performed using an Euclidean distance matrix derived, using the DE genes for the tissues with the hclust function in $\mathrm{R}(42)$. The pvclust package $(9)$ in $\mathrm{R}$ was used to calculate the uncertainty in the hierarchical clustering with a 1000 bootstrap value.

\section{ATAC-seq library preparation}

810 We prepared ATAC libraries for the same set of tissues as we did for the RNA-seq experiment, 811 except for the eyespot control tissues (Table S7). Library preparation failed for a few groups 812 leading to 2 to 4 biological replicates per group. Tissues were collected, flash-frozen in liquid nitrogen and stored in $-80^{\circ} \mathrm{C}$, before we extracted nuclei and prepared the libraries. We used 10 to 25 individuals and approximately 80,000 nuclei per replicate. Libraries were prepared as described in the Omni-ATAC protocol (43) with slight modifications. Individual tissues extracted at different time periods during the process were randomized and pooled into each replicate before extracting the nuclei. The tissues were thawed and homogenized in $2 \mathrm{~mL}$ of ice cold 1X homogenization buffer (HB) in a 2-mL-glass douncer. Homogenization was 

mixture was left on ice for 2 min before filtering it through a $100-\mu \mathrm{m}$ - nylon mesh filter into a DNA "low bind" 2-mL Eppendorf tube (Z666556-250EA). The filtered mixture was centrifuged at $2500 \mathrm{rpm}$, and the pellet (the nuclei) was collected along with $50 \mu \mathrm{L}$ of the solution at the bottom, keeping unwanted cytoplasmic RNAs in the top layers. The filtered nuclei were diluted in ATAC-Resuspension Buffer (RSB buffer), and $10 \mu \mathrm{L}$ of the solution were used to count the nuclei, using a hemocytometer. Approximately 80,000 cells were used for each replicate to prepare the libraries. The tagmentation enzyme (TDE1) was obtained from Illumina (Illumina tagment dna tdel enzyme and buffer smaller kits - 20034197). As the concentration of the TDE1 and cell number greatly affect the identification of open chromatin regions, we estimated the amount of enzyme needed for each reaction, using the formula: volume of enzyme $=$ genome size of $B$ anynana $[475 \mathrm{MB}] *$ number of cells $[80,000] * 2.5 /$ (genome size of humans $[3200 \mathrm{MB}] * 50,000$ ). We used $0.65 \mu \mathrm{L}$ (final concentration of 10.4 $\mathrm{nM}$ ) of enzyme for each reaction. The Omni-ATAC transposition reaction was carried out as follows: 80,000 cells suspended in ATAC-RSB buffer were centrifuged at $2500 \mathrm{rpm}$ for 10 min at $4^{\circ} \mathrm{C}$. The supernatant was removed, and the nuclei-containing pellet was kept. To perform the cell lysis, $50 \mu \mathrm{L}$ of ice-cold ATAC-RSB were added to the pellet, along with $0.1 \%$ NP40, $0.1 \%$ Tween 20, and $0.01 \%$ Digitonin. The mixture was incubated for $3 \mathrm{~min}$ on ice. Subsequently, $1 \mathrm{~mL}$ of ATAC-RSB buffer containing only $0.1 \%$ Tween and no NP40 nor digitonin was added, and the mixture was centrifuged at $2500 \mathrm{rpm}$. The supernatant was discarded, and the pellet was retained, to which $50 \mu \mathrm{L}$ of transposition mixture $(6.5 \mu \mathrm{L} 2 \mathrm{x}$ TD buffer, $0.65 \mu \mathrm{L}$ transposase (10.4 nM final concentration), $16.5 \mu \mathrm{L}$ PBS, $0.5 \mu \mathrm{L} 1 \%$ digitonin, $0.5 \mu \mathrm{L} 10 \%$ Tween-20, $25.35 \mu \mathrm{L} \mathrm{H}_{2} \mathrm{O}$ ) were added. The reaction was incubated for 25 minutes at $37^{\circ} \mathrm{C}$ at $1000 \mathrm{rpm}$ in a thermomixer. After the transpositions and tagmentation occurred, the samples were prepared for sequencing by adding Illumina/Nextera adapters with dual indexing and further PCR amplified for 10 cycles. The PCR products were purified, using a Zymo-DNA Clean \& Concentrator-5 kit, and the DNA fragments were size-selected between $50-1500 \mathrm{bp}$, using the ProNex Size-Selective Purification System (NG2002) from Promega. The samples were sequenced, using Novoseq 6000 with an average read depth of 30 million and 2x50 bp paired end reads by AIT Novogene, Singapore.

\section{ATAC-seq peak calling}

ATAC reads were processed, using bbduk scripts from bbmap tools, to remove any adapters. The reads were mapped to the BaGv2 genome, using bowtie with the $-x 1500$ and $-\mathrm{m} 1$ parameters. Only reads with insert sizes of $1500 \mathrm{bp}$ or less and only those mapping to a unique region of the genome were mapped. Reads mapped to the mitochondrial genome were removed, using samtools idxstats, and reads marked for PCR duplicates were also removed, using GATK Markduplicates. We kept only paired-end mapped reads with a phred quality score of Q20 and above for downstream analysis. Because the Tn5 transposase binds to DNA as a dimer and inserts adapters of $9 \mathrm{bp}$ in length at the insertion sites, the start sites of the mapped reads were adjusted to an offset of $+4 \mathrm{bp}$ in the forward strand and $-5 \mathrm{bp}$ in the reverse strand. The bam files were converted to bed files, using Bedtools (31), and we used F-Seq (44) to call peaks for each sample. Bedtools intersect was used to identify the common set of peaks 
for each tissue type. Peaks from all samples were merged if they were separated by $50 \mathrm{bp}$, using Bedtools merge to create 313,425 consensus peaks used for the downstream analyses. Featurecount from the Subread package(45) was used to extract a read count matrix corresponding to the consensus peaks for all samples. The FRiP score, which is defined as the fraction of all reads that are mapped to peaks across the entire genome, was used to measure the quality of the ATAC-seq data. Our ATAC-seq data showed a median FRiP score of 0.846 , which is higher than the ENCODE standard $(>0.3)$ for the fraction of reads falling into peaks (Table S8). And deepTools (46) was used to access the sample correlation between the replicates and quality of the libraries (Fig. S26).

\section{ATAC-seq differential peak analysis:}

Differential peak analysis was performed using DESeq2. Peaks were considered differentially accessible with a padj value of 0.05 . We also mapped the Dll319 peak identified from the FAIRE data to the BaGv2 genome, using blastn, to identify its position in the new genome assembly and test whether the ATAC-seq analysis was also able to identify it. To identify potential CREs for sal, ATAC peaks from $3 \mathrm{hr}$ pupal tissues were visualized using IGV and we targeted one potential candidate region (sal740) within the intronic region of sal gene loci which is open across almost of the tissues.

\section{Hi-C analysis and Virtual $4 \mathrm{C}$}

The Hi-C library used for scaffolding the B. anynana genome was reanalyzed, using the Dll319 and sal740 region as bait, to verify whether these regions interacted with the promoter of $D l l$ and sal respectively. Libraries were mapped to the BaGv2 assembly, using Juicer (47). We used the contact map obtained from Juicer to construct a virtual $4 \mathrm{C}$ plot for the window around the Dll319 and sal740 regions by placing reads in a 3-kb bin, using the script from Ray et al., 2019 (48).

\section{Screening and genotyping sal 740 crispants}

Caterpillars that emerged were carefully screened under the microscope for any defects in their body, especially in the head region where sal expression is observed. Individuals showing any abnormalities were imaged and grown separately in a cup whereas all others were grown in a separate cage. Adults were immediately frozen at $-20^{\circ} \mathrm{C}$ after emergence and screened later under a microscope for any defects in eyespots, wings, legs and in antenna.

\section{Hi-C Genome Assembly}

Eggs were collected from a single pair of mated B. anynana butterflies and reared. Eighteen female siblings were harvested at the wandering stage for DNA extraction. Guts were removed, and the samples were immediately flash-frozen in liquid nitrogen and stored at $-80{ }^{\circ} \mathrm{C}$ before the samples were sent to Dovetail Genomics to perform Chicago and Hi-C library preparation and analysis. The Chicago library preparation uses in vitro chromatin fixation, digestion, and crosslinking of regions in the genome that are close to each other in terms of 3D chromatin architecture. In order to sort and scaffold the genome, 233 million reads (2x150bp) were sequenced from the Chicago library and mapped to the previously published B. anynana genome (v1.2) with 10,800 scaffolds(49). The HiRise pipeline was used to identify mis- 
assemblies, to break the scaffolds, and to sort the scaffolds. Only scaffolds greater than $1 \mathrm{~kb}$ in length ( $n=5027)$ were used because scaffolds needed to be long enough for the read pairs to align and be scaffolded in accordance with the likelihood model used by HiRise. Next, 153 million reads $(2 * 150)$ sequenced from the Hi-C library were mapped to the genome assembly output generated from the Chicago-HiRise pipeline to identify any mis-assemblies from the Chicago pipeline and correct them to produce a final genome assembly of high contiguity. The genome assembly obtained from the $\mathrm{HiC}$ pipeline was ordered, using the available linkage information from Beldade et al., (2009)(50), using Chromonomer(51). Two hundred eightynine SNP FASTA sequences were mapped to the Hi-C assembly, using blastn to identify their corresponding positions in the Hi-C genome. Using the SNP position obtained from blastn, a list describing the genetic map was manually created, which later passed through Chromonomer to sort the Hi-C assembly resulting in the final assembly (BaGv2) that was used for the current study. The BUSCO score(52) was used to check for the completeness of the gene sets in the assembly.

\section{Genome Annotation}

The genome was repeat-masked for transposable elements, small repeats, and tandem repeats before annotation as described in Nowell et al., 2017 (49) The soft repeat-masked genome was annotated, using four rounds of Maker v.3 (39). The transcriptome assembled from the RNASeq data and gene sequences annotated from the previous version of the genome were combined and used as transcripts for the species, with transcriptome and protein sequences from Pieris rapi, Junonia coenia, and Bombyx mori as relative transcripts and protein homology evidences for the first round of gene predictions. Output gene predictions from each round were used as input for the next round. Snap and Augustus were used for the second round of gene predictions, followed by Genemark for the third round of gene modelling. Then we performed one final round of Snap and Augustus predictions. The minimum length of 35 amino acids was set for gene predictions. The predicted gene models were kept for genes that had an Annotation Edit Distance (AED) score of $<1$ and/or had a gene ontology obtained from Interproscan (53). This resulted in 18,189 genes with 29,490 transcripts. In order to correct the annotations and produce a standardized gff3 file, the gff file obtained from Maker was run through agat_convert_sp_gxf2gxf.pl script, which is a part of AGAT tools (54). This step resulted in the removal of 82 identical isoforms and added the missing gene features, leading to a total of 18,196 genes with 29,389 transcripts. Functional annotation was performed by locally blasting the transcripts against a non-redundant (nr) protein database, using diamond blast (55), and a gene ontology analysis was performed using Interproscan in Blast2Go(56). Finally, the blast results were merged with the interproscan results in Blast2Go to produce a final functional annotation for the genome.

\section{Supplementary Results}

\section{Bicyclus anynana Hi-C Genome Assembly}

The published version of the B. anynana genome assembly (475 MB) contains 10,800 scaffolds with an N90 value of $99.3 \mathrm{kB}$ (49). To improve the current assembly, we performed scaffolding, using a two-step approach, one with Chicago-HiRise followed by Hi-C-based 
scaffolding. Chicago-HiRise scaffolding performed on the published version resulted in 3512 new joins with 634 breaks remaining in the genome, raising the $\mathrm{N} 90$ value to $840 \mathrm{kB}$. The Hi-

953 C scaffolding that followed corrected mis-joints from the Chicago-HiRise scaffolding by 954 creating four new breaks but made 512 new joints, improving the N90 value further to 12.073 $955 \mathrm{MB}$ and placing $98 \%$ of the bases (467.62 MB) into 28 scaffolds, achieving a near956 chromosomal level assembly. Following the Hi-C assembly and using the linkage map from 957 Beldade et al. (2009)(50) obtained for the 28 chromosomes of $B$. anynana, we produced one 958 manual break and one joint to achieve congruence of the two data sets. We were able to map 959171 markers out of the 289 markers from the 28 linkage groups (50) in the genome, resulting 960 in an ordered chromosomal level assembly of $475.8 \mathrm{MB}$ 
A

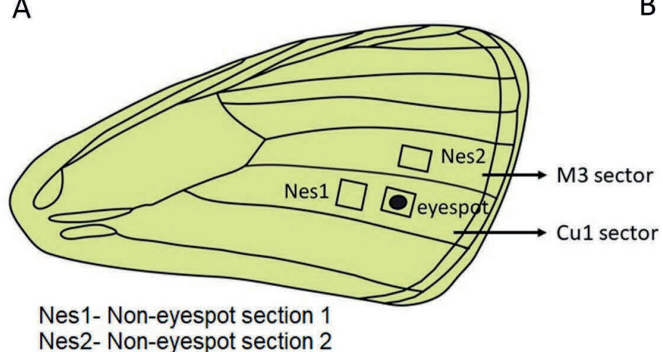

\begin{tabular}{|c|c|c|c|c|c|c|}
\hline \multirow{3}{*}{$\begin{array}{l}\text { Eyespot- } \\
\text { specific } \\
\text { genes }\end{array}$} & Comparisons & $\begin{array}{l}\text { Total } \\
\text { differentially } \\
\text { expressed } \\
\text { genes }\end{array}$ & $\begin{array}{l}\text { Up- } \\
\text { regulated } \\
\text { genes }\end{array}$ & $\begin{array}{l}\text { Down- } \\
\text { regulated } \\
\text { genes }\end{array}$ & $\begin{array}{l}\text { Common } \\
\text { up- } \\
\text { regulated } \\
\text { genes }\end{array}$ & $\begin{array}{l}\text { Common } \\
\text { down- } \\
\text { regulated } \\
\text { genes }\end{array}$ \\
\hline & $\begin{array}{l}\text { eyespot vs. } \\
\text { Nes1 }\end{array}$ & 6229 & 3633 & 2666 & \multirow[t]{2}{*}{370} & \multirow[t]{2}{*}{282} \\
\hline & $\begin{array}{l}\text { eyespot vs. } \\
\text { Nes2 }\end{array}$ & 1110 & 582 & 528 & & \\
\hline
\end{tabular}

Fig. S1. Tissue selection to identify eyespot-specific DE genes. (A) Forewing image highlighting the regions chosen to perform DE analysis to identify eyespot genes. Nes1 and Nes2 are two control tissues representing tissue from the same and from a more anterior wing sector, where no eyespots develop. (B) Table Showing the number of genes differentially expressed (DE) in each of the comparisons, leading to 652 eyespot-specific DE genes that were in common across both comparisons.

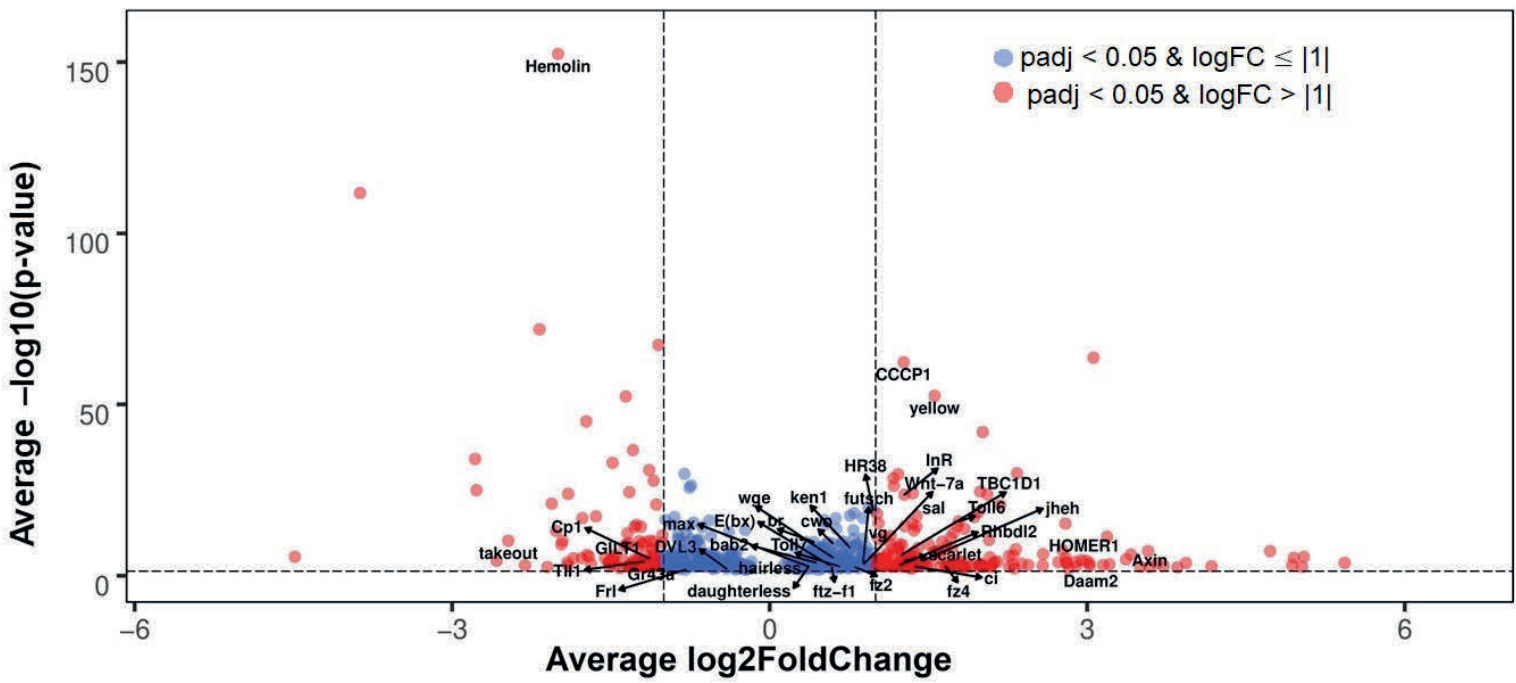

Fig. S2. Set of DE genes between the "eyespot" and "control" wing tissues (with adjusted $p$ values $<0.05)$. Up-regulated genes show a positive $\mathrm{X}$-axis value, while down-regulated genes show a negative $\mathrm{X}$-axis value. The $\log 2 \mathrm{FC}$ and $p$-values were averaged among the two control tissue comparisons. 


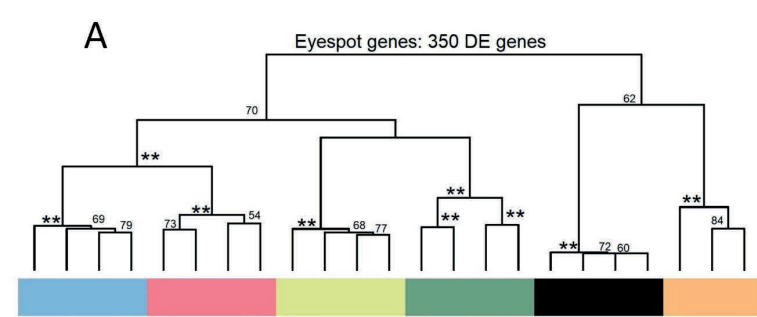

C

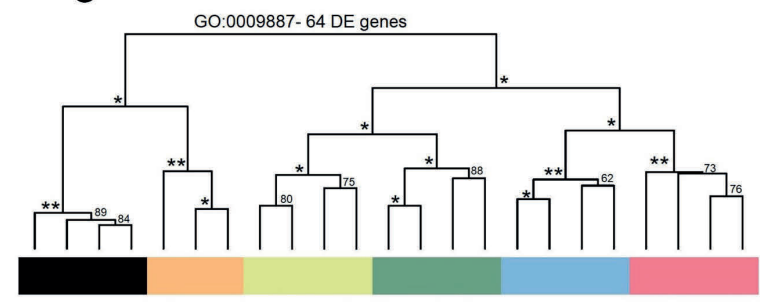

E

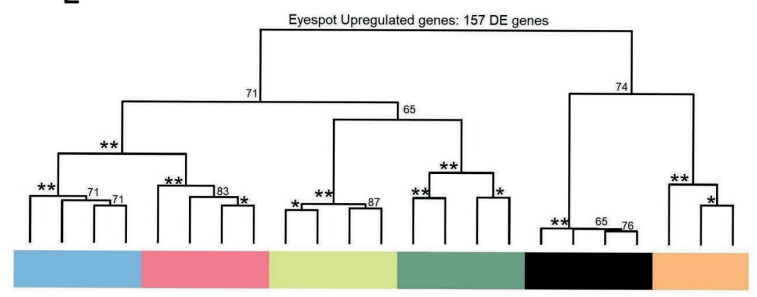

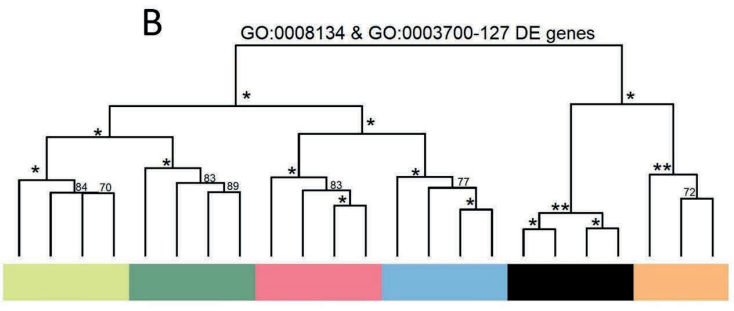

D
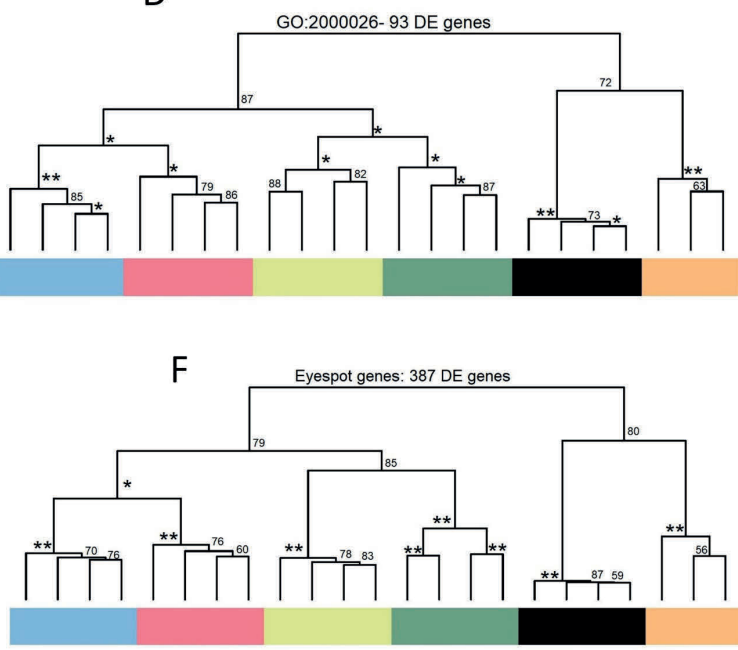

1020

1021

1022

1023

1024

1025

1026

1027

1028

1029

1030

1031

1032

1033

1034

1035

1036

1037

1038

1039

1040

1041

1042

1043

1044

1045

Fig. S3. Character trees for 3-h pupal tissues, using various gene subsets revealing that eyespot gene expression patterns cluster with those of antennae. "DE genes" represents the number differentially expressed genes (padj $<0.001$ and $\log 2 \mathrm{FC} \geq|2|$ ) from the initial subset of genes. Trees constructed using: A. eyespot-specific genes (652 genes), B. Transcription factors and co-factors (336 genes), C. genes enriched for GO terms associated with animal organ morphogenesis (108 genes), D. genes enriched for GO terms corresponding to anatomical structure formation involved in morphogenesis (165 genes), E. genes up-regulated in eyespots (370 genes), F. combined eyespot-specific DE genes predicted in this study as well as those published in Ozsu and Monteiro 2017 (10) (a total of 775 genes). In all six trees, eyespots gene expression patterns cluster with those of antennae and form an outgroup in the tree with another clade where eyes cluster with legs, and wings with wing margins. 
bioRxiv preprint doi: https://doi.org/10.1101/2021.03.01.429915; this version posted March 1, 2021. The copyright holder for this preprint (which was not certified by peer review) is the author/funder, who has granted bioRxiv a license to display the preprint in perpetuity. It is made available under aCC-BY 4.0 International license.

regulation of cellular component organizatio wound healing cell-cell junction animal organ morphogenesis negative regulation of cellular process cell adhesion molecule binding embryonic forelimb morphogenesis calcium-dependent cell-cell adhesion via plasma membrane cell adhesion molecules structural constituent of pupal chitin-based cuticle negative regulation of apoptotic process anatomical structure formation involved in morphogenesis positive regulation of cellular component organizationneural crest cell development chemotaxis regulation of biological quality tube morphogenesis Wnt-protein binding mucosal immune response apical part of cell-

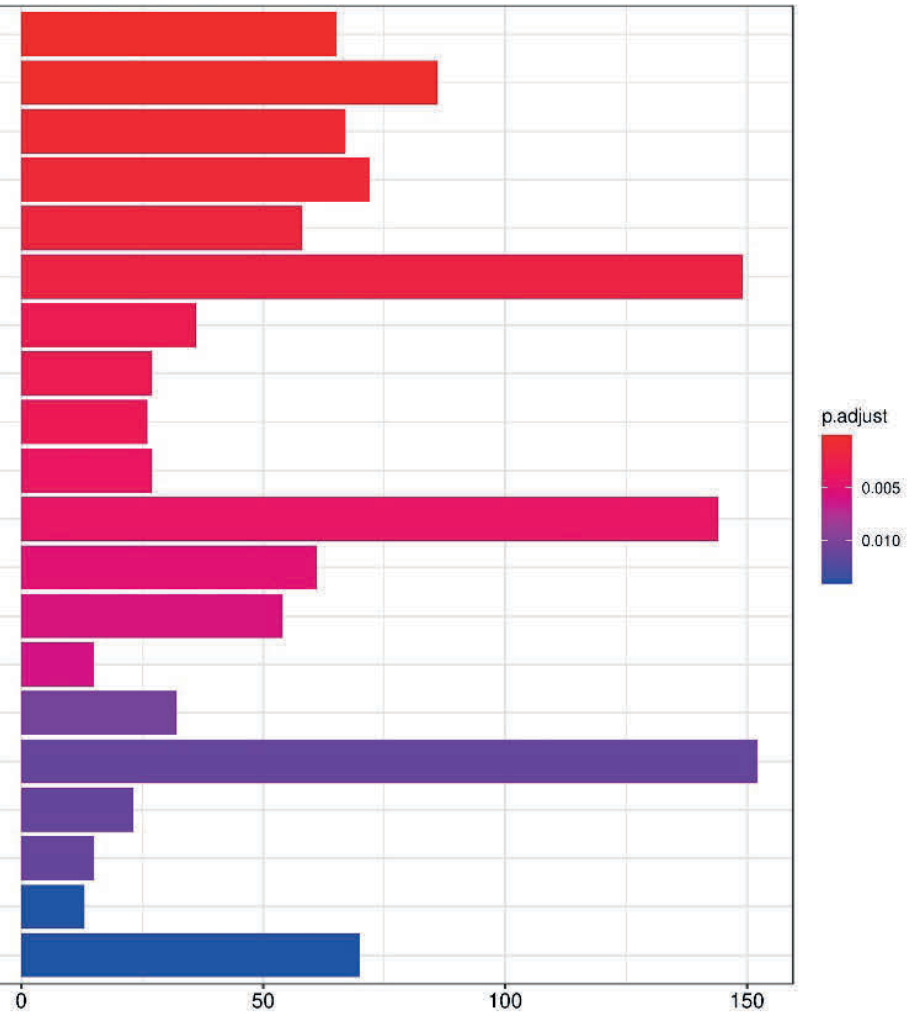

Fig. S4. Gene-set-enrichment plot for the 3839 DE genes from 3-h pupal tissues. The geneenrichment analysis shows the various functions DE genes are involved. 


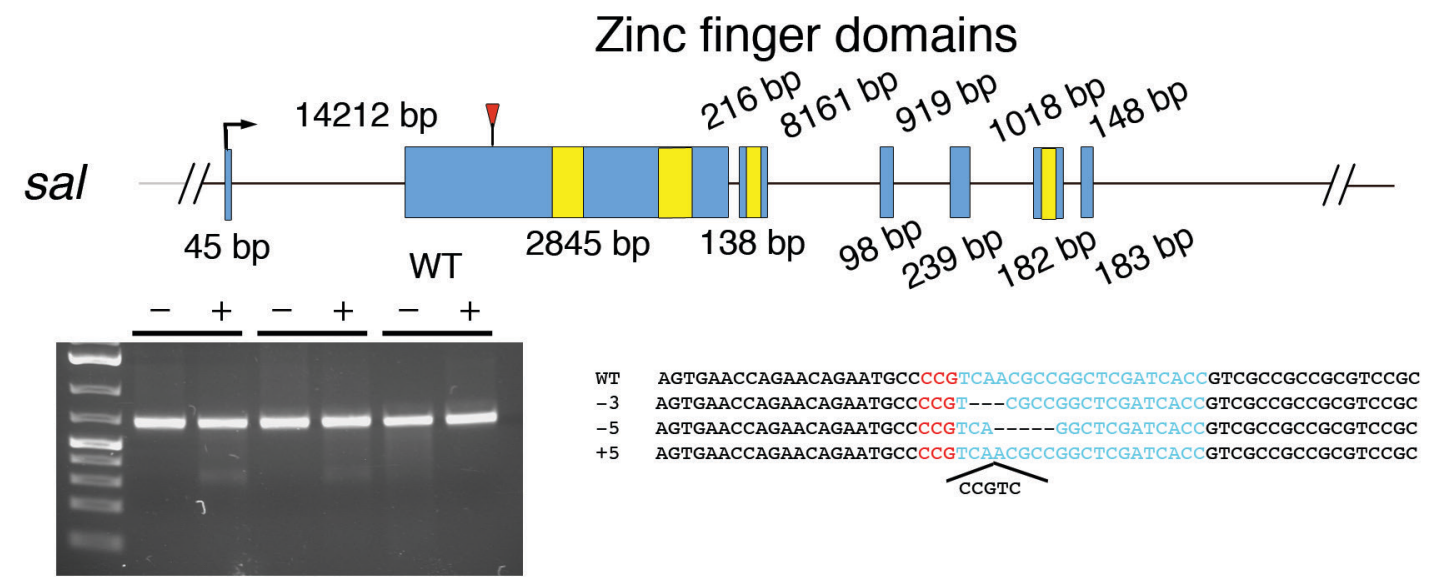

1073

1074

1075

1076

1077

1078

1079

1080

1081

1082

1083

1084

1085

1086
Fig. S5. T7 endonuclease I assay and sequence analysis for CRISPR-Cas9 mutations in sal. Schematic representation of the sal gene structure. Blue boxes indicate exons, and yellowcoloured regions inside exons indicate functional domains. Each functional domain was annotated using a conserved-domain search at NCBI. Red arrowheads indicate the CRISPR target region. The gel shows the result of a $\mathrm{T} 7$ endonuclease assay performed on embryos after injection of sgRNA and Cas9 mRNA or protein or performed on Wt embryos (last two lanes). We performed the assay with two different samples for technical replicates. "Minus" lanes indicate a negative control, where T7 endonuclease was not added to the reaction. "Plus" lanes indicate the presence of $\mathrm{T} 7$ endonuclease. The expected sizes of digested bands were observed only from the lanes containing the T7 enzyme. Sanger sequence results indicate that an indel mutation was generated around the target site. Blue-coloured sequences indicate the sgRNA target sequence, and red-coloured sequences indicate the PAM sequence. 

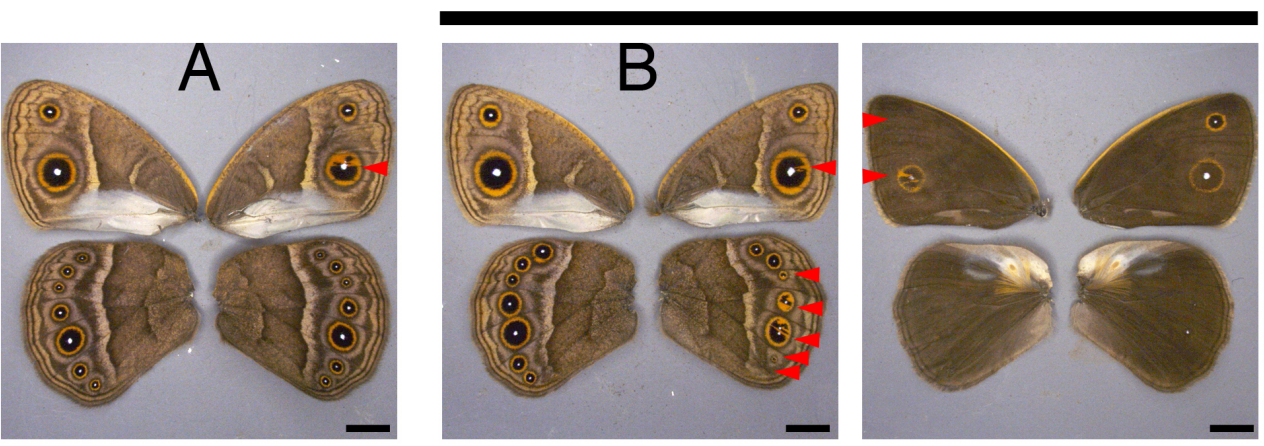

\section{Dorsal}

\section{Ventral}
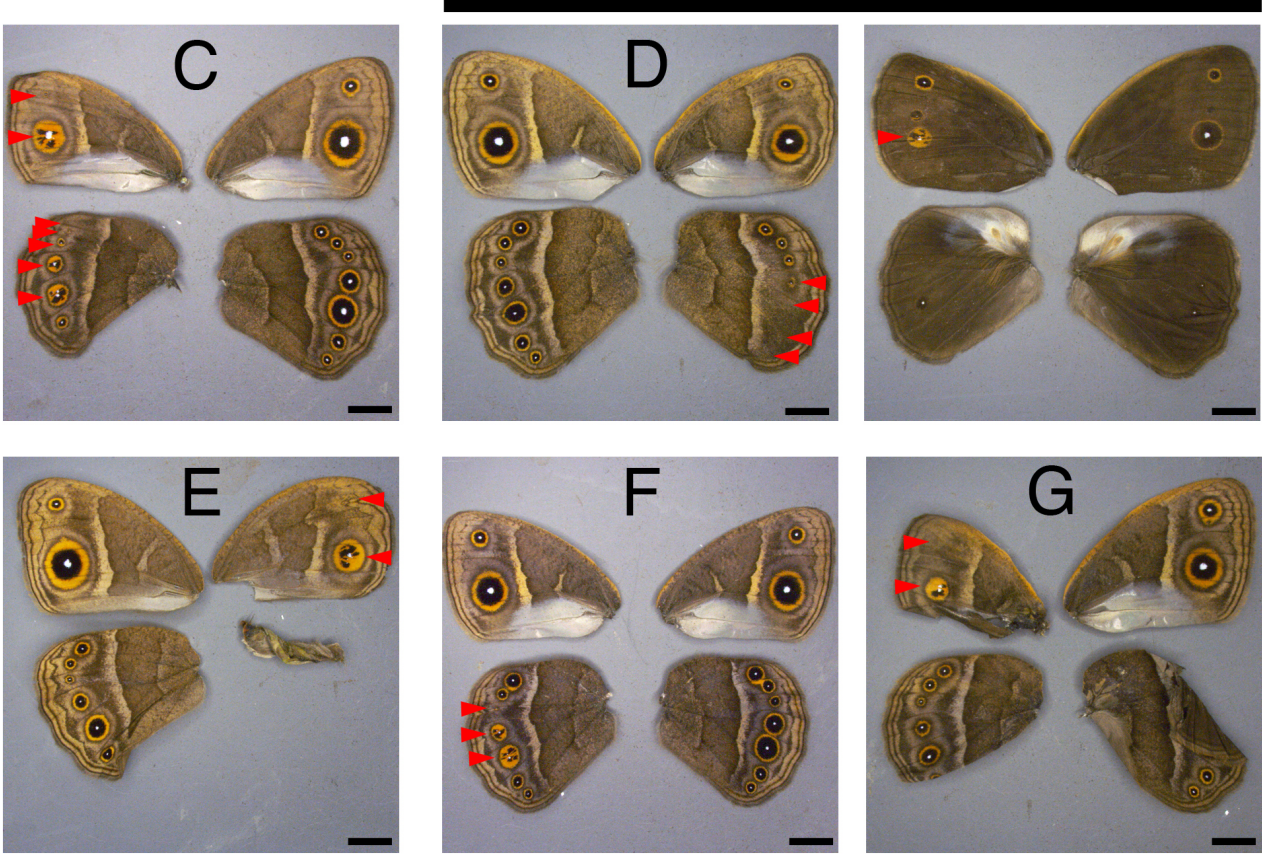

Fig. S6. sal crispant phenotypes

(A) The $\mathrm{Cu} 1$ eyespot on the right forewing showed a transformation of orange scales into black scales. (B) The $\mathrm{Cu} 1$ eyespot on the right forewing and the M1, M2, M3, and Cu1 eyespots on the right hindwing showed transformation of black into orange scales. The $\mathrm{Cu} 2$ eyespot got reduced in size, and the A1 eyespot on the right hindwing disappeared. On the dorsal side, the $\mathrm{M} 1$ eyespot on the right forewing disappeared, but the $\mathrm{Cu} 1$ eyespot on the right forewing showed a transformation of black into orange scales. (C) The M1 eyespot on the left forewing was reduced in size, and the $\mathrm{Cu} 1$ eyespot showed a transformation of black into orange scales. On the hindwing, the Rs eyespot disappeared, and the M1, M2, M3, and Cu1 eyespots showed transformation of black into orange scales. (D) The M3 eyespot was reduced in size, and the $\mathrm{Cu} 1, \mathrm{Cu} 2$, and $\mathrm{A} 1$ eyespots disappeared. On the dorsal forewing, the $\mathrm{Cu} 1$ eyespot showed transformation of black into orange scales. (E) The M1 eyespot on the right forewing was reduced in size, and the $\mathrm{Cu} 1$ eyespot showed transformation of black into orange scales. The chevron pattern on the wing margin and the central symmetry system bands running the length of each wing were distorted. (F) The M2, M3, and Cu1 eyespots on the left hindwing showed 
1103 transformation of black into orange scales. (G) The M1 eyespot on the left forewing 1104 disappeared, and the $\mathrm{Cu} 1$ eyespot showed transformation of orange into black scales. Mutated 1105 eyespots are marked with red arrowheads. Scale; $5 \mathrm{~mm}$.
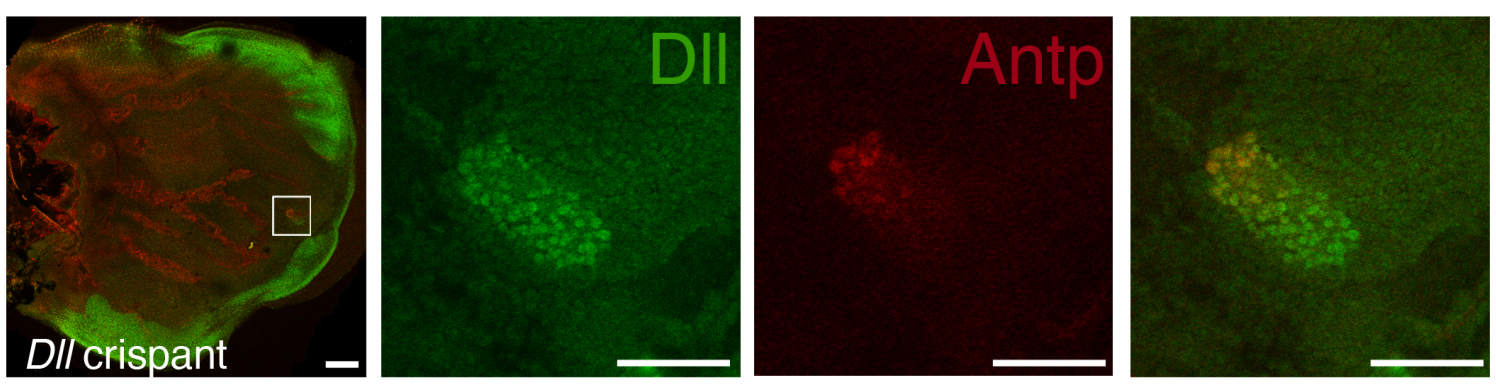

Fig. S7. Expression pattern of Dll and Antp proteins in a Dll crispant

1113 Antp expression was only observed within the Dll-positive cells. Scale; $100 \mu \mathrm{m}$ for low magnification and $50 \mu \mathrm{m}$ for high magnification. 

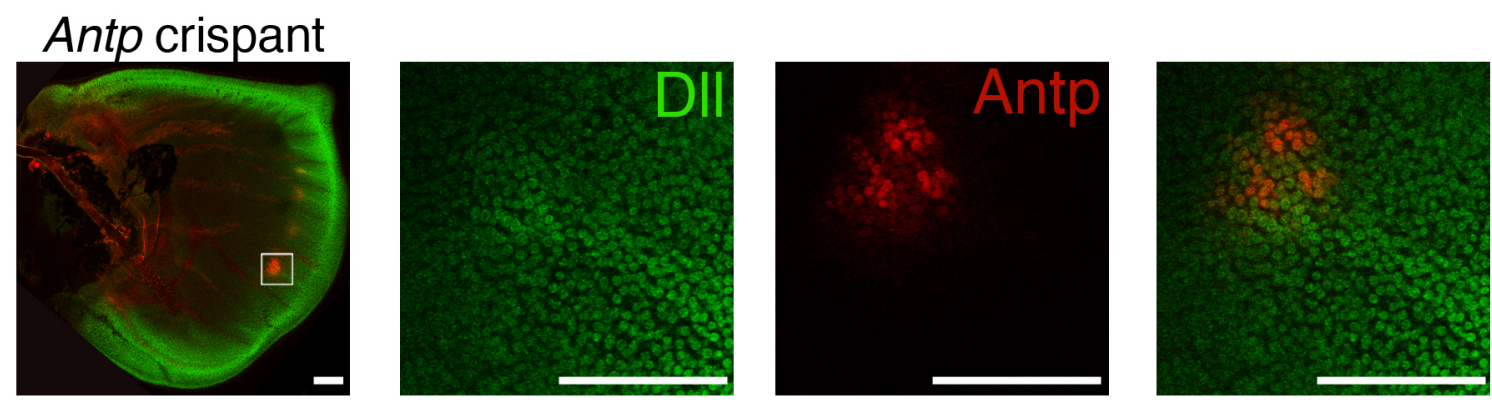

Fig. S8. Expression pattern of Dll and Antp proteins in an Antp crispant

1118 (A) Antp expression in Cu1 eyespot was partially lost, but Dll expression was not affected. Scale; $100 \mu \mathrm{m}$ for low magnification and $50 \mu \mathrm{m}$ for high magnification. 


\section{DIl crispant}
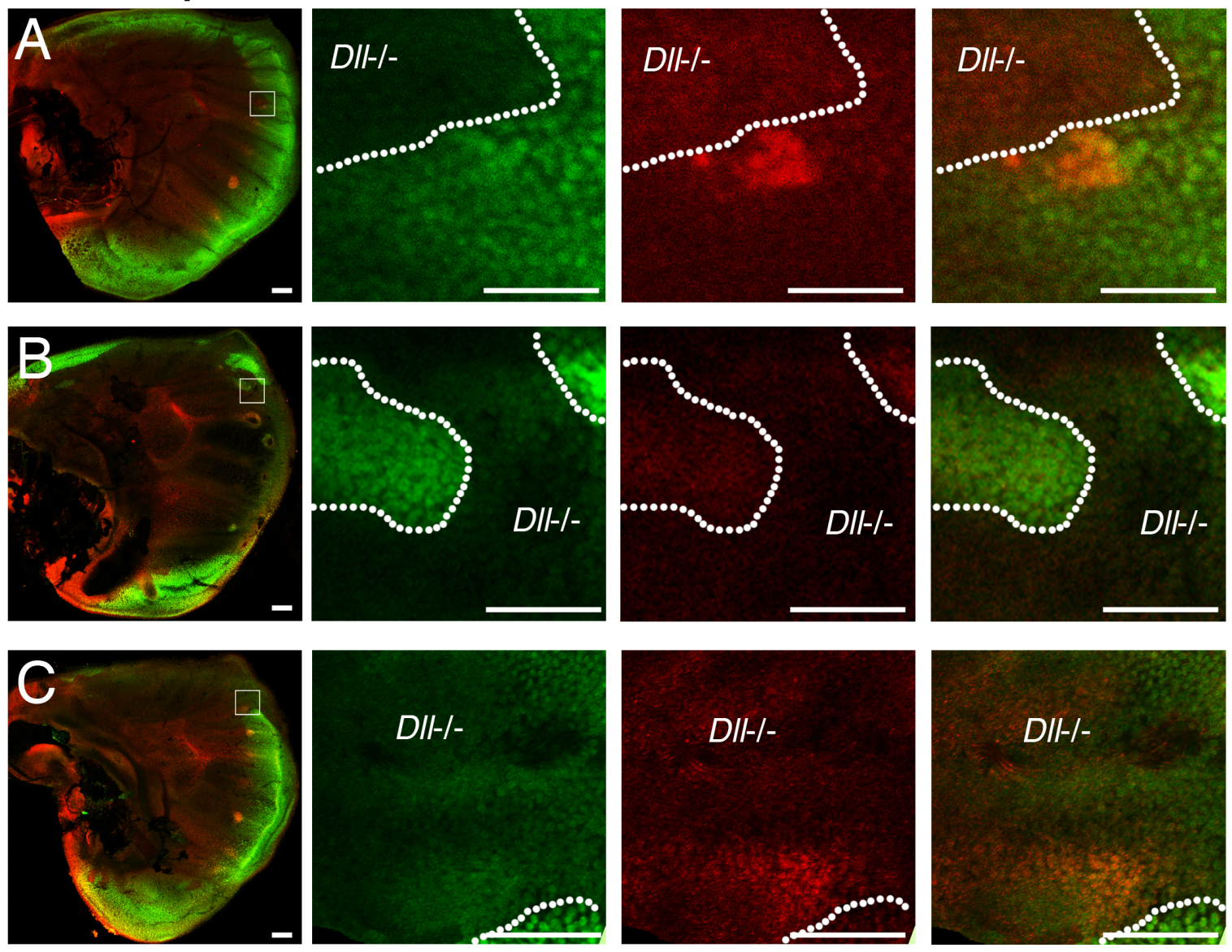

1122

Fig. S9. Expression pattern of Dll and Sal proteins in Dll crispants

1123 (A) Sal expression was lost in Dll null mutant cells of the M1 eyespot. (B) Cells from the middle of the wing were broadly mutated and lost Sal activity. (C) Cells anterior to the M1 eyespot were mutated, which resulted in the loss of Sal expression in the eyespot centres. (D) Cells from the middle of the wing were broadly mutated, and in some wing sectors, Sal was ectopically expressed in the distal wing region. Scale; $100 \mu \mathrm{m}$ for low magnification and 50 $\mu \mathrm{m}$ for high magnification. 

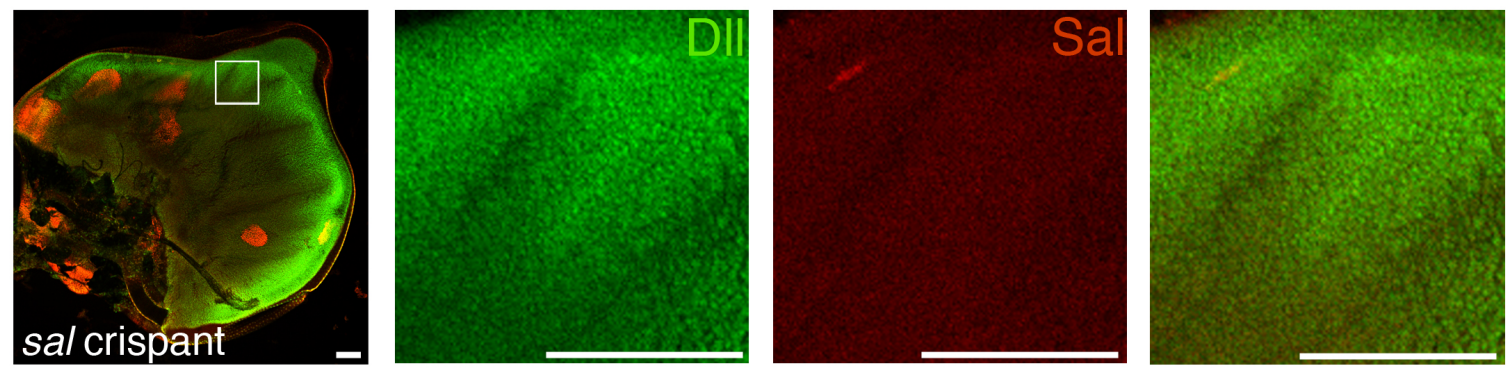

Fig. S10. Expression pattern of DII and Sal proteins in a sal crispant

1133 The distal wing region was broadly mutated for Sal activity, but D1l expression was not 1134 affected. Scale $50 \mu \mathrm{m}$. 
bioRxiv preprint doi: https://doi.org/10.1101/2021.03.01.429915; this version posted March 1, 2021. The copyright holder for this preprint (which was not certified by peer review) is the author/funder, who has granted bioRxiv a license to display the preprint in perpetuity. It is made available under aCC-BY 4.0 International license.
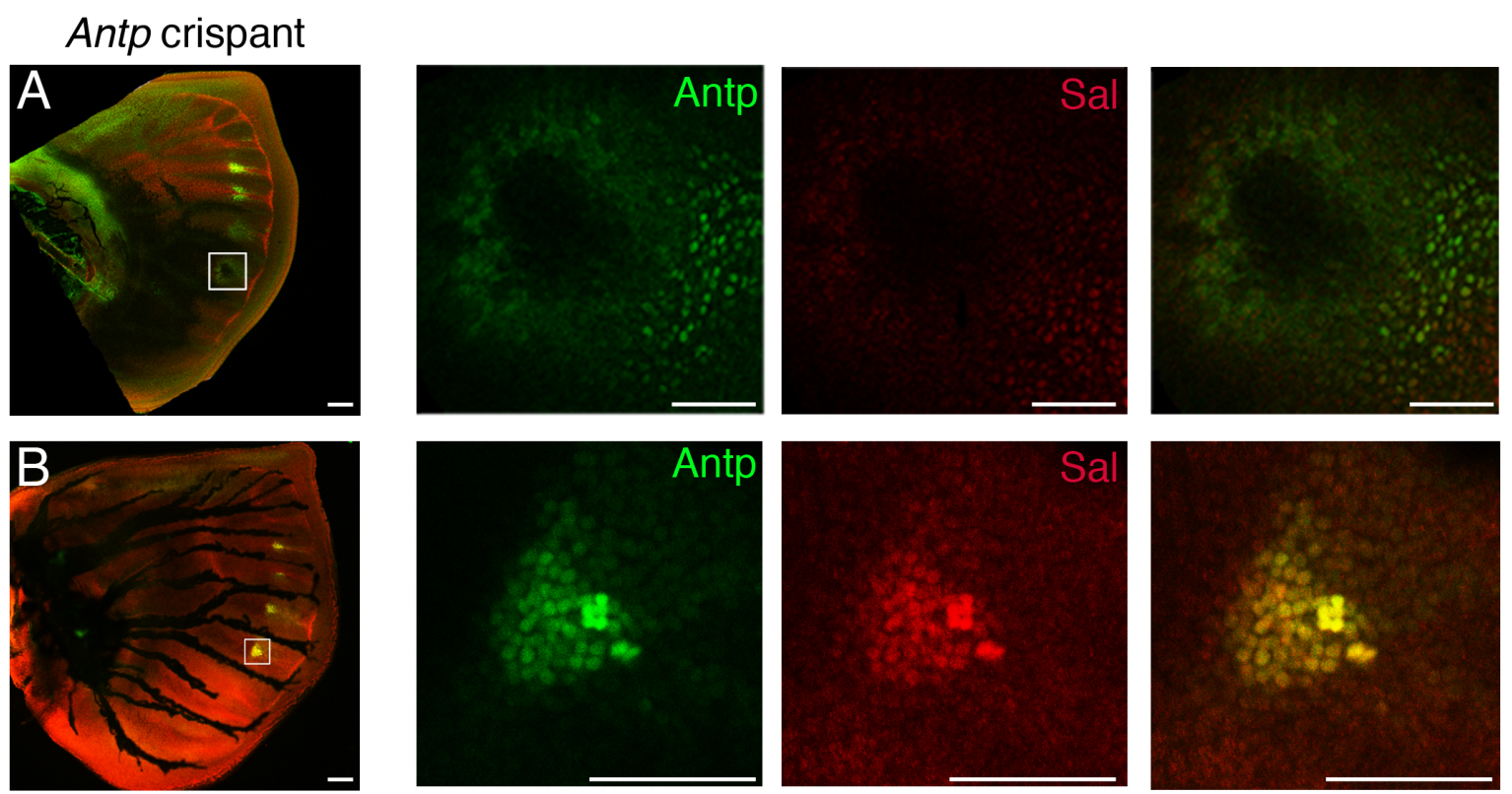

Fig. S11. Expression pattern of Antp and Sal proteins in Antp crispants

(A) Sal expression was lost in Antp null mutant cells in the Cu1 eyespot. (B) Some Cu1 eyespot cells lost Antp activity, and Sal expression was only detected in the Antp-positive cells. Scale; $100 \mu \mathrm{m}$ for low magnification and $50 \mu \mathrm{m}$ for high magnification. 


\section{sal crispant}
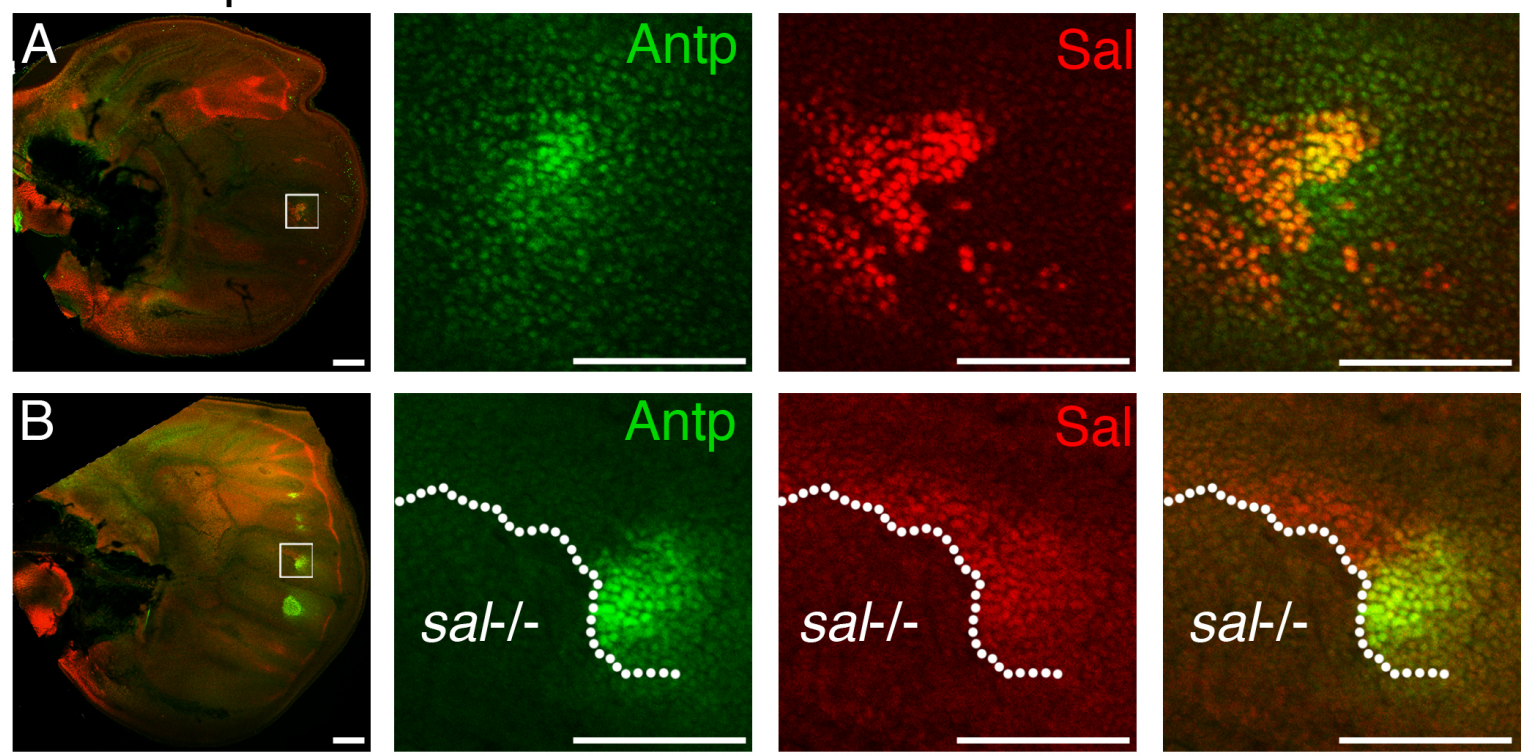

1143 Fig. S12. Expression pattern of Antp and Sal proteins in sal crispants

(A) The wing is broadly mutated for Sal activity. Some Cul eyespot cells lost Sal expression, and Antp expression was only detected in the Sal-positive cells. (B) Cells around the M3 eyespot were mutated, and Antp expression was detected only in the Sal-positive cells. Scale; $100 \mu \mathrm{m}$ for low magnification and $50 \mu \mathrm{m}$ for high magnification. 
bioRxiv preprint doi: https://doi.org/10.1101/2021.03.01.429915; this version posted March 1, 2021. The copyright holder for this preprint (which was not certified by peer review) is the author/funder, who has granted bioRxiv a license to display the preprint in perpetuity. It is made available under aCC-BY 4.0 International license.

A
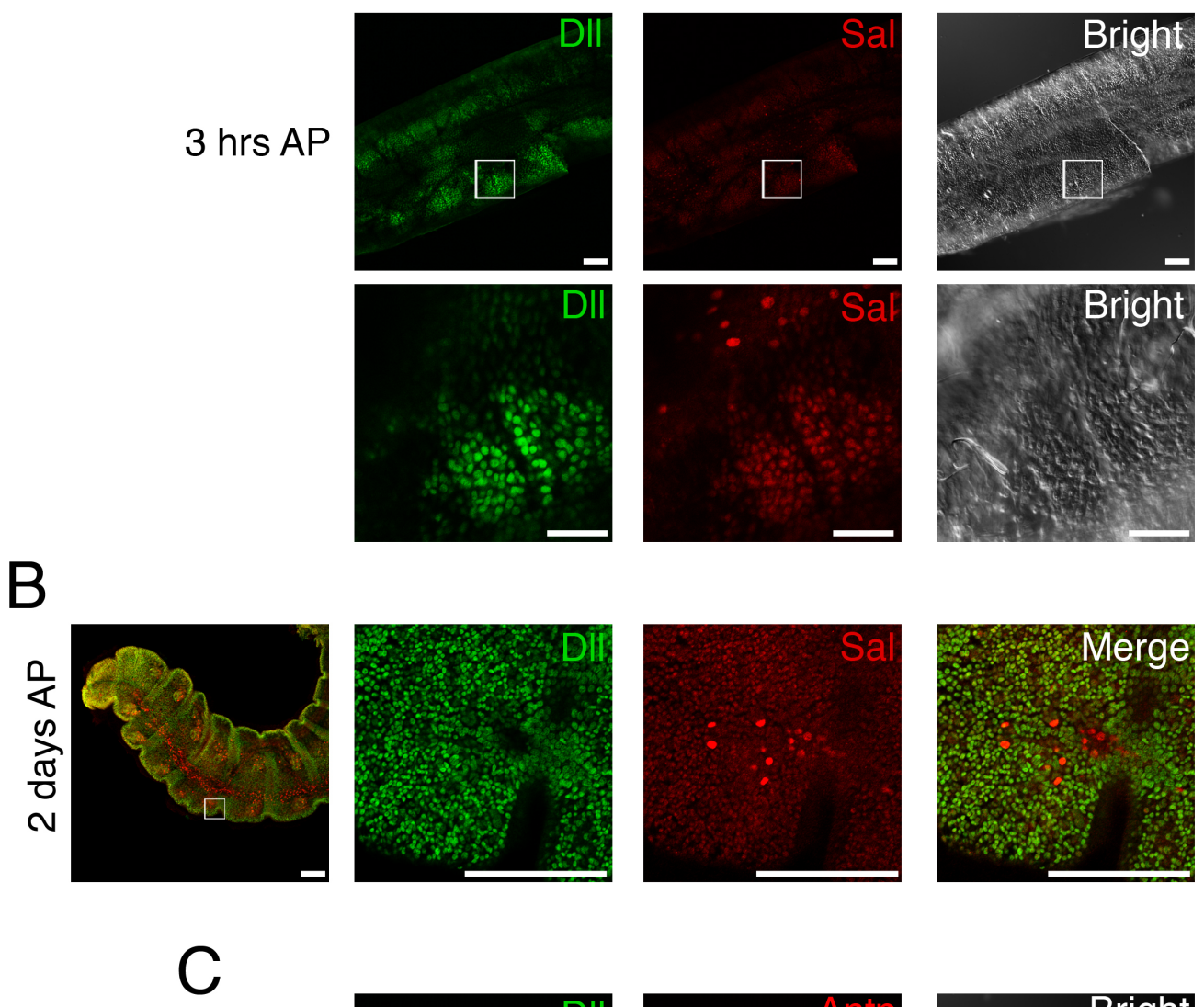

$3 \mathrm{hrs}$ AP
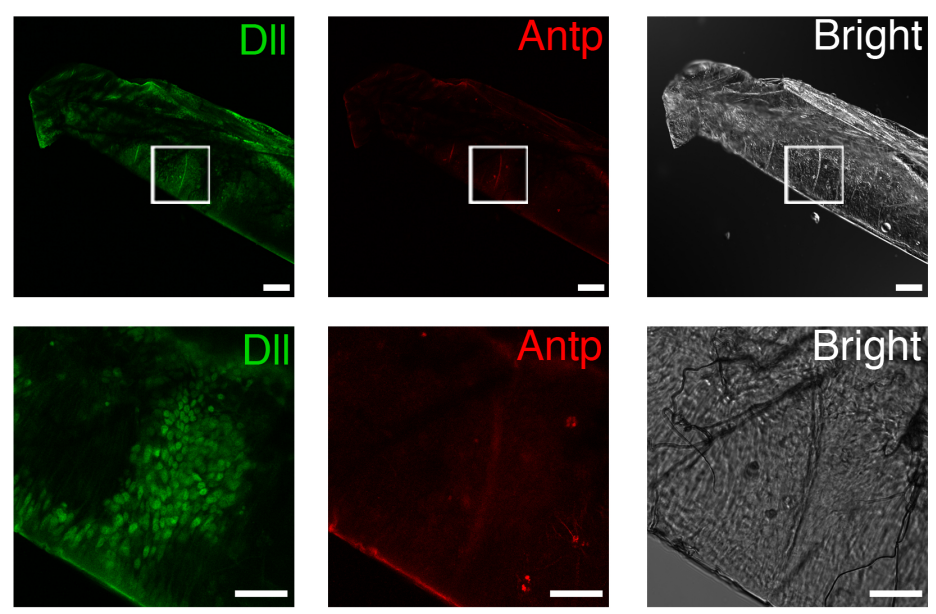

Fig. S13. Expression of Dll, Sal, and Antp proteins in pupal antennae

(A) Dll and Sal were co-expressed in the segments of the developing antenna of a 3-h-old pupa.

(B) Expression patterns of Dll and Sal in the pupal antenna, 2 days after pupation (AP). Dll was ubiquitously expressed in the antenna, but Sal expression is observed in the neurons. (C) Expression patterns of Dll and Antp in the antenna of a 3-h-hold pupa. Antp expression was not observed in the antenna. The regions within the white squares are shown at higher magnification. Scale; $100 \mu \mathrm{m}$ for low magnification and $50 \mu \mathrm{m}$ for high magnification. 
bioRxiv preprint doi: https:/doi.org/10.1101/2021.03 01.429915. this version posted March 1, 2021. The copyright holder for this preprint (which was not certified by peer review) is the author/funder, who has granted bioRxiv a license to display the preprint in perpetuity. It is made available under aCC-BY 4.0 International license.

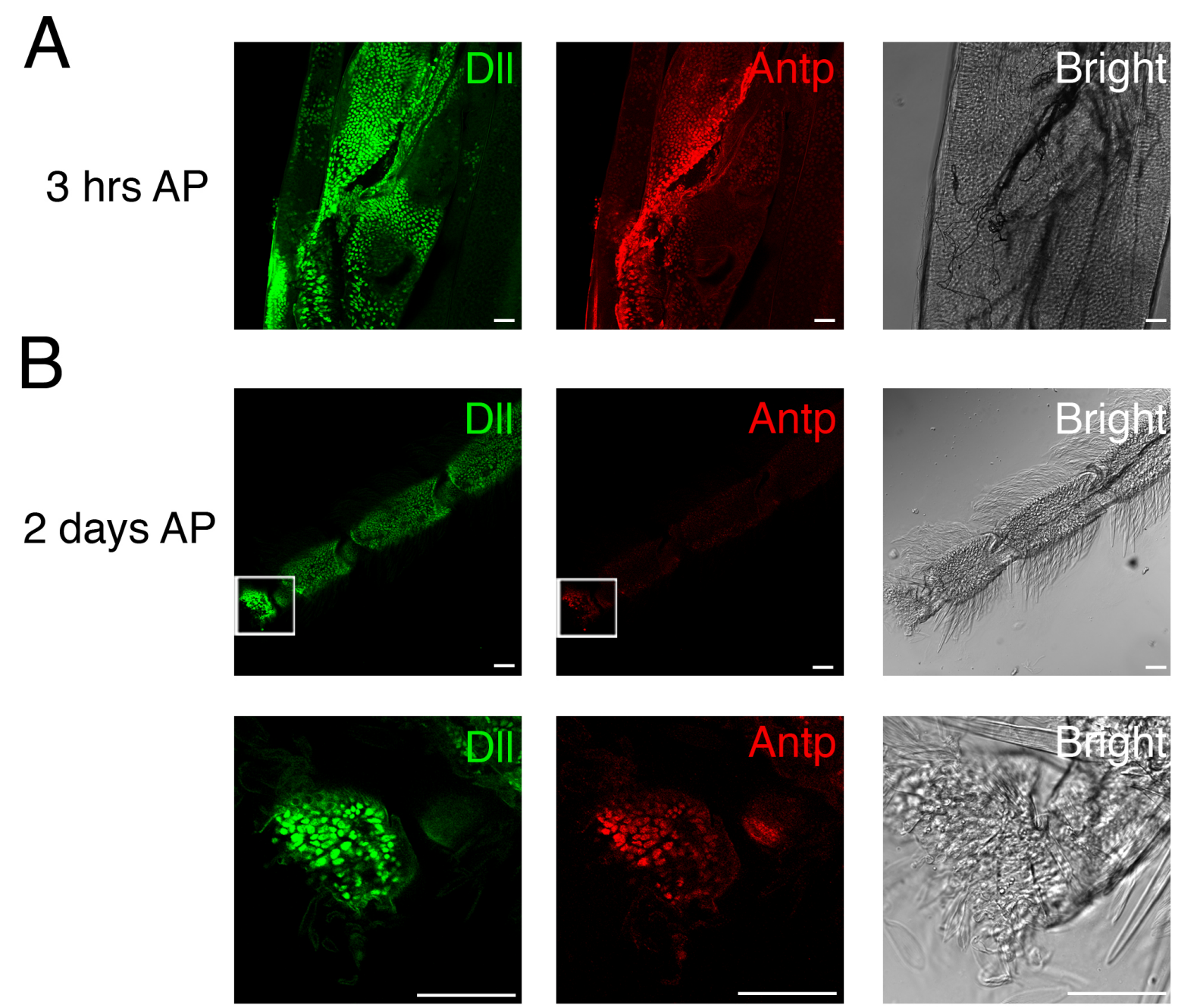

Fig. S14. Expression patterns of Dll, and Antp proteins in pupal legs

1161 (A) Expression pattern of D1l and Antp in the developing leg of a 3 -h-old pupa. Dll and Antp are co-localized in the developing pupal leg. (B) Expression patterns of Dll and Antp in the leg of a 3-days-old pupa. Dll is ubiquitously expressed in the distal region of a developing pupal leg. Antp is also expressed in the developing pupal leg. The regions within the white squares are shown at higher magnification. Scale; $100 \mu \mathrm{m}$. 
bioRxiv preprint doi: https://doi.org/10.1101/2021.03 01.429915. this version posted March 1 2021. The copyright holder for this preprint (which was not certified by peer review) is the author/funder, who has granted bioRxiv a license to display the preprint in perpetuity. It is made available under aCC-BY 4.0 International license.

1166

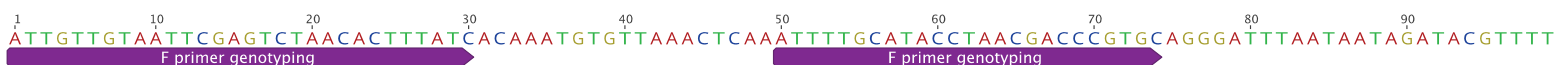

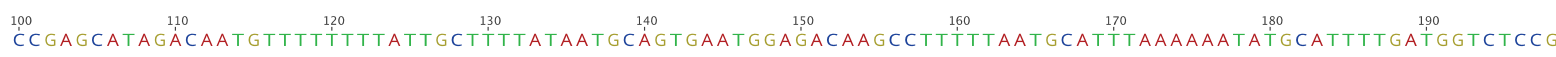

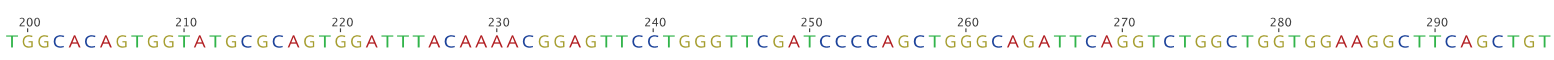

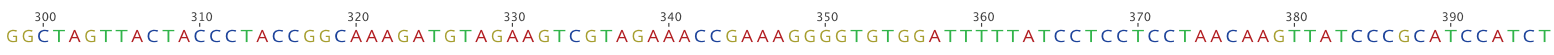
TAGATTGCATCATCACTTACCATCA 40.40 TCATCATCATCATCAATCAATGGAC 50

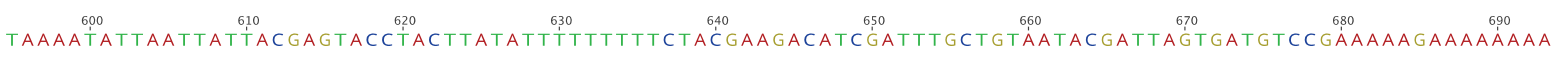

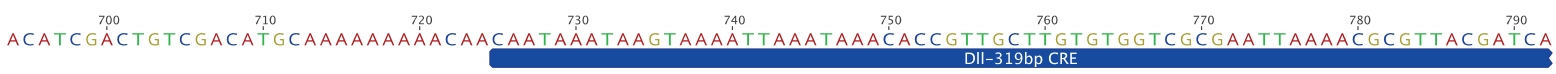

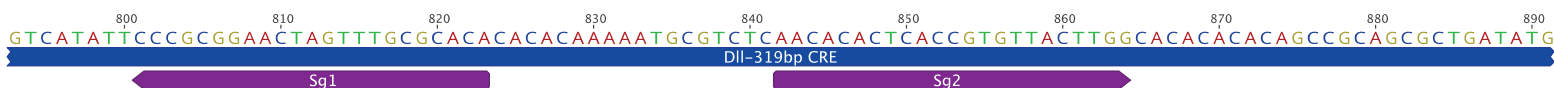

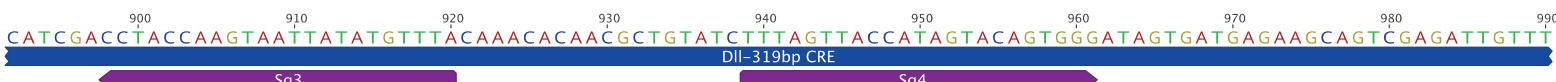

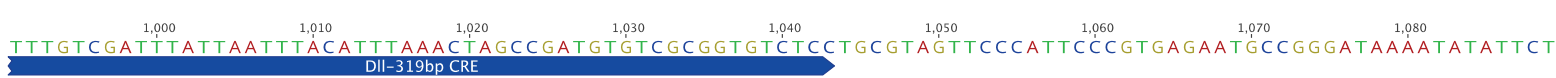

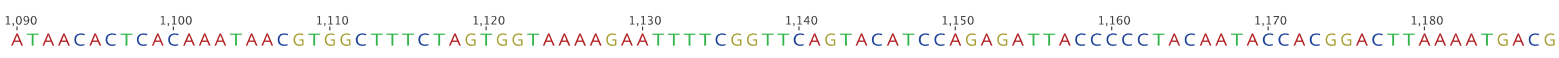

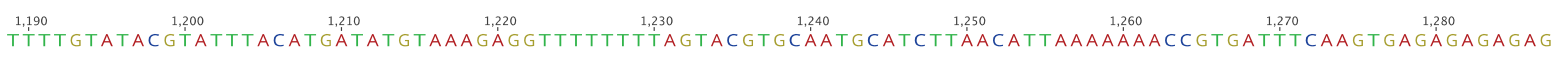

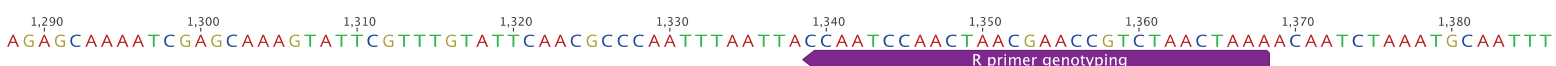

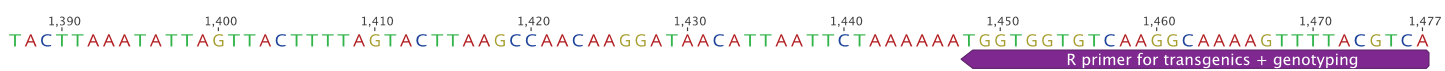

Fig. S15. Dll319 CRE annotated with CRISPR guides and primers used for the transgenics and genotyping crispants. 


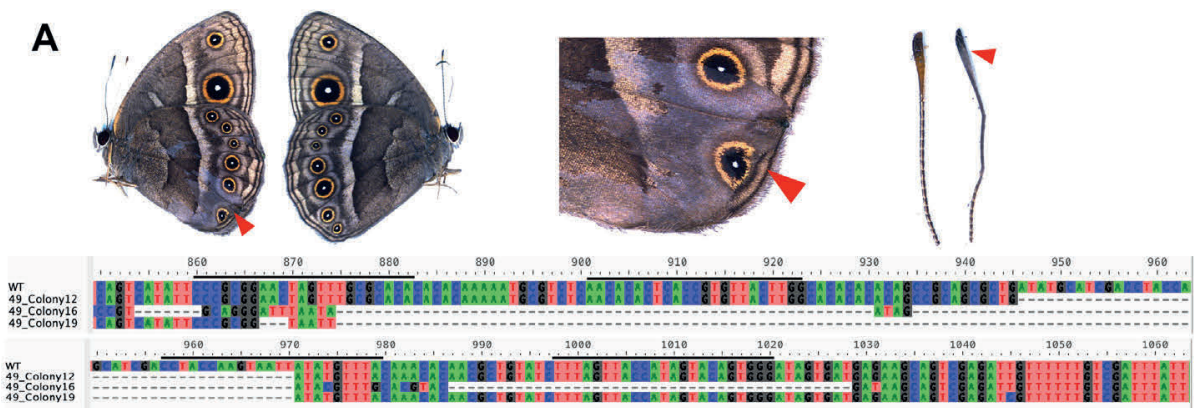

B
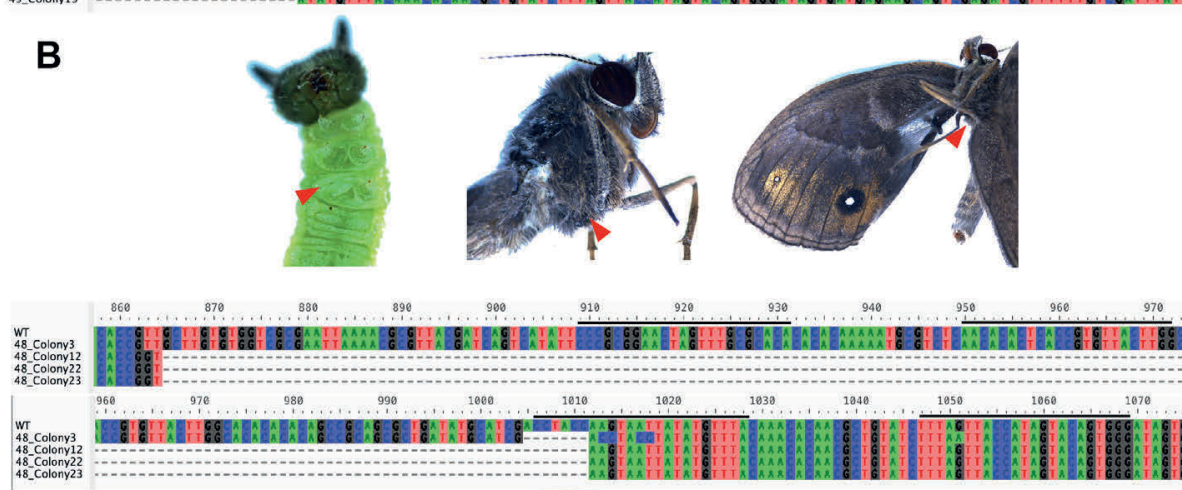

C
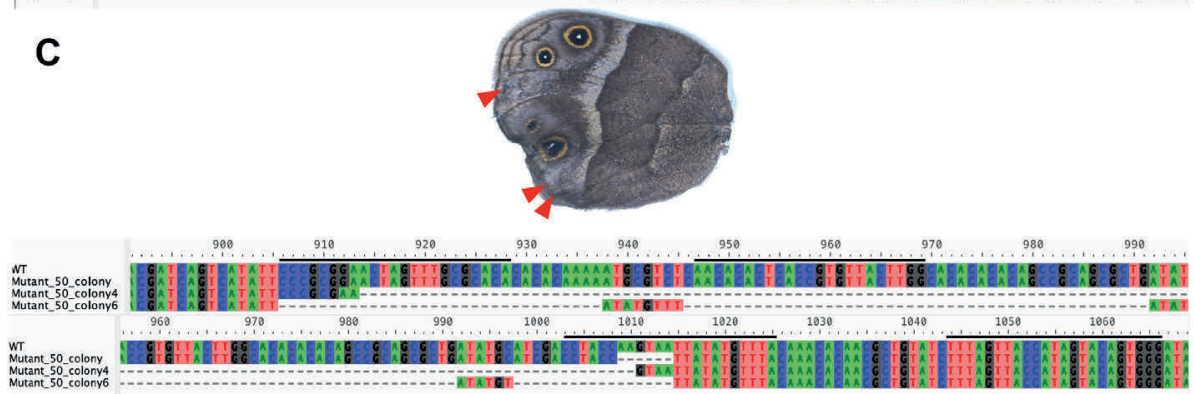

D

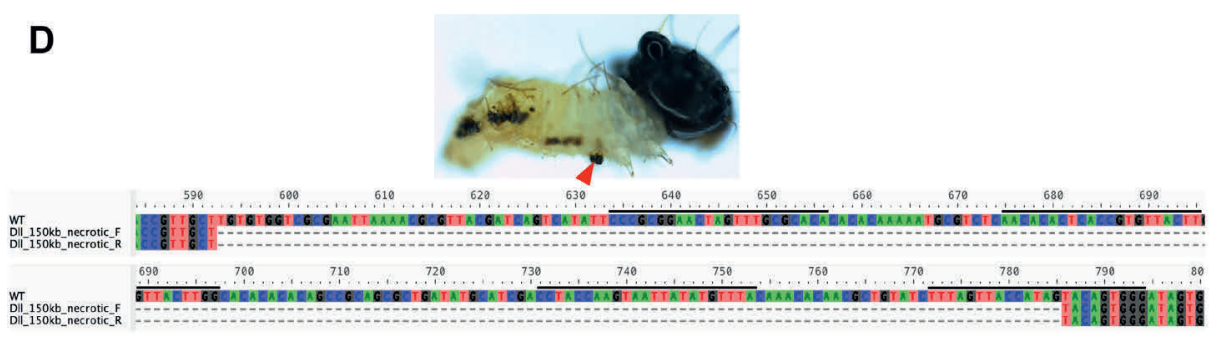

1186 Fig. S16. Sanger sequencing results following CRISPR-targeting of the Dll319 CRE in four crispant individuals, WT refers to the wild-type sequence. Positions of the CRISPR guides are shown as horizonal black lines above each sequence. (A) Colony PCR sequencing results with variable sized deletions for a crispant with a missing eyespot; pigmentation defects are visible on the wing and antenna. The left image shows the wing defects. The mirror image on the right shows wild-type wing phenotype. (B) The same individual from Fig. 3C is shown with a missing T3 leg in the larva and adult, as well as a missing wing. The sequence of a colony PCR product revealed a $147 \mathrm{bp}$ deletion. (C) Colony PCR sequencing result showing a $108 \mathrm{bp}$ deletion for an individual with three missing eyespots. (D) Sanger sequencing showing a 193 
bioRxiv preprint doi: https//doi.org/10.1101/2021.03.01.429915; this version posted March 1, 2021. The copyright holder for this preprint (which was not certified by peer review) is the author/funder, who has granted bioRxiv a license to display the preprint in perpetuity. It is made available under aCC-BY 4.0 International license.

bp deletion from a whole larva that showed areas of necrosis and a missing distal tip of a T3 leg.
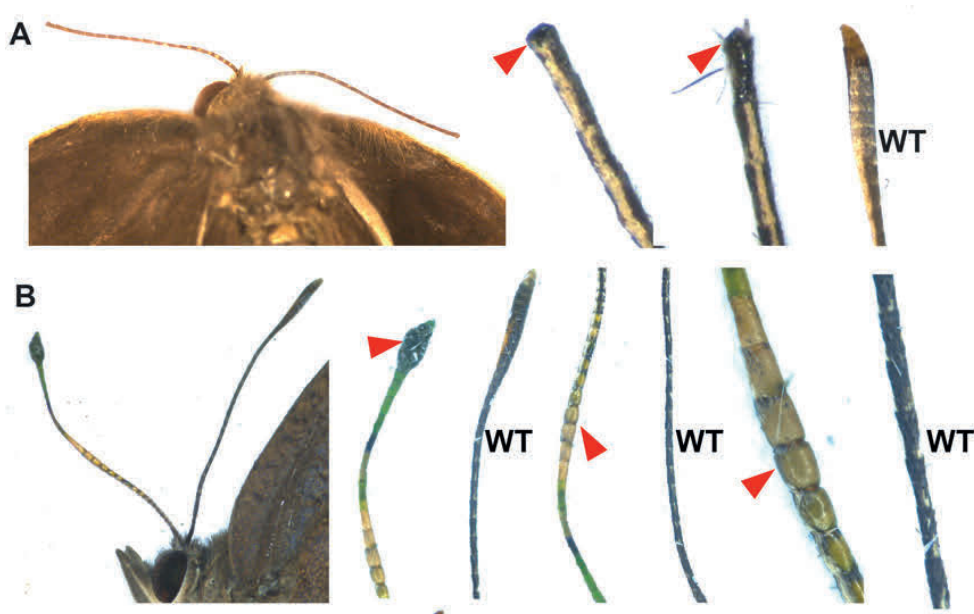

c
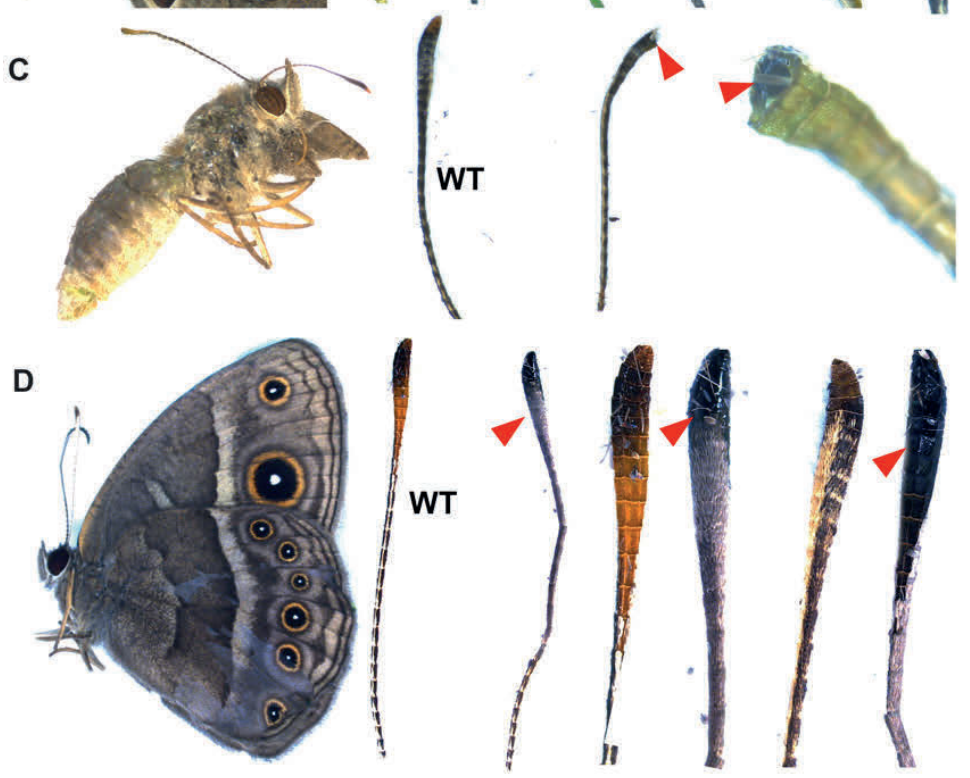

Fig. S17. Four individual crispants showing antennal deformities following disruption of the Dll319 CRE. (A) Both antennae of this butterfly were missing the distal tip. (B) One antenna showed a developmental abnormality, changing the shape of the distal tip. Additionally, the stem of the antenna had a different morphology to the wild-type and also showed loss of scales. (C) The very distal tip of one antenna in this individual was missing. (D) One antenna was crooked and showed a change in pigmentation from brown to grey. Furthermore, we noted a loss of scales on one side of the antenna that has been replaced by a shiny black cuticle, as compared to wild-type. Red arrows point to the antennae with developmental defects. 
bioRxiv preprint doi: https://doi.org/10.1101/2021.03.01.429915; this version posted March 1, 2021. The copyright holder for this preprint

(which was not certified by peer review) is the author/funder, who has granted bioRxiv a license to display the preprint in perpetuity. It is made available under aCC-BY 4.0 International license.

1215

1216

1217

1218

1219

1220

1221

1222

1223

1224

1225

1226

1227

1228

1229

1230

1231

1232

1233

1234

1235

1236

1237

1238

1239

1240

1241

1242

1243

1244

1245

Fig. S18. Targeting of the Dll319 CRE led to losses of either T2 or T3 legs.

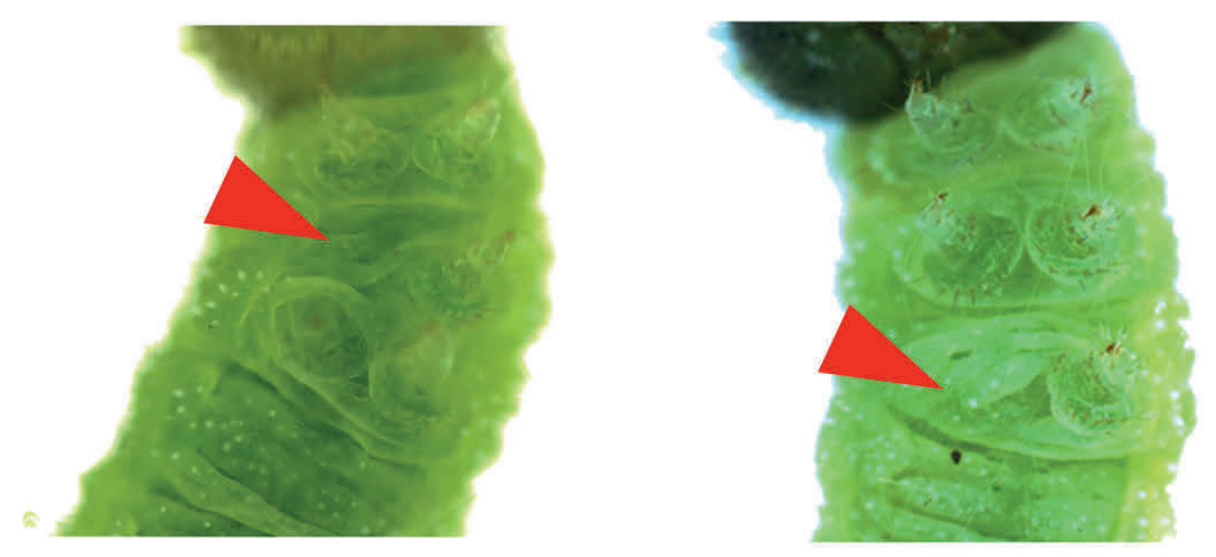



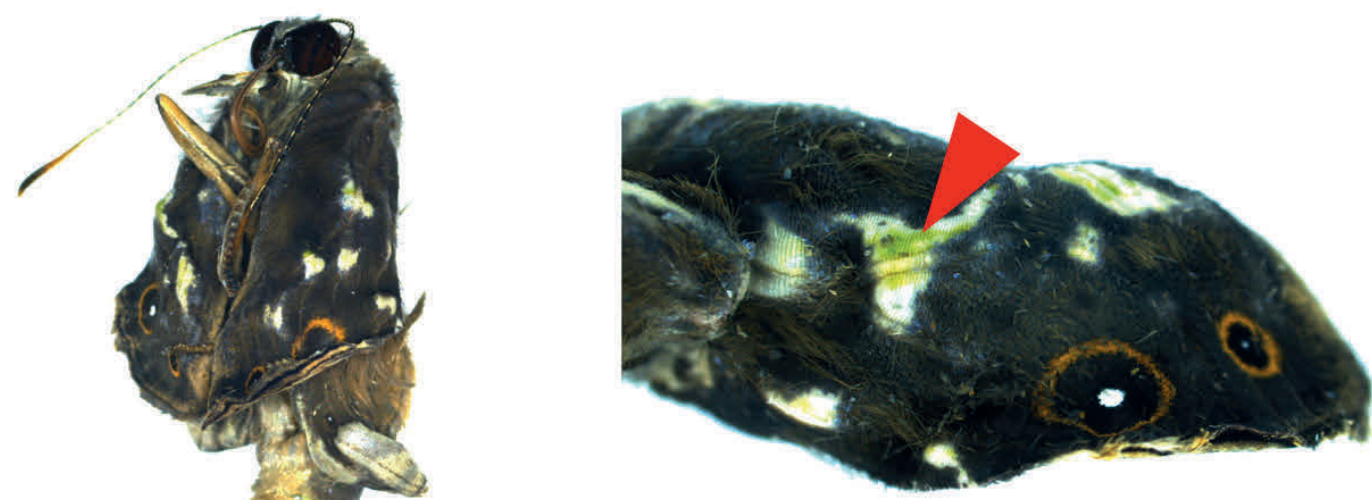

Fig. S19. A Dll319 crispant shows white wing patches due to a complete loss of wing scales.

1248

1249

1250

1251

1252

1253

1254

1255

1256

1257

1258

1259

1260

1261

1262

1263

1264

1265

1266

1267

1268

1269

1270

1271 
bioRxiv preprint doi: https://doi.org/10.1101/2021.03.01.429915; this version posted March 1, 2021. The copyright holder for this preprint (which was not certified by peer review) is the author/funder, who has granted bioRxiv a license to display the preprint in perpetuity. It is made available under aCC-BY 4.0 International license.

1272

1273

1274

1275

1276

1277

1278

1279

1280

1281

1282

1283

1284

1285

1286

1287

1288

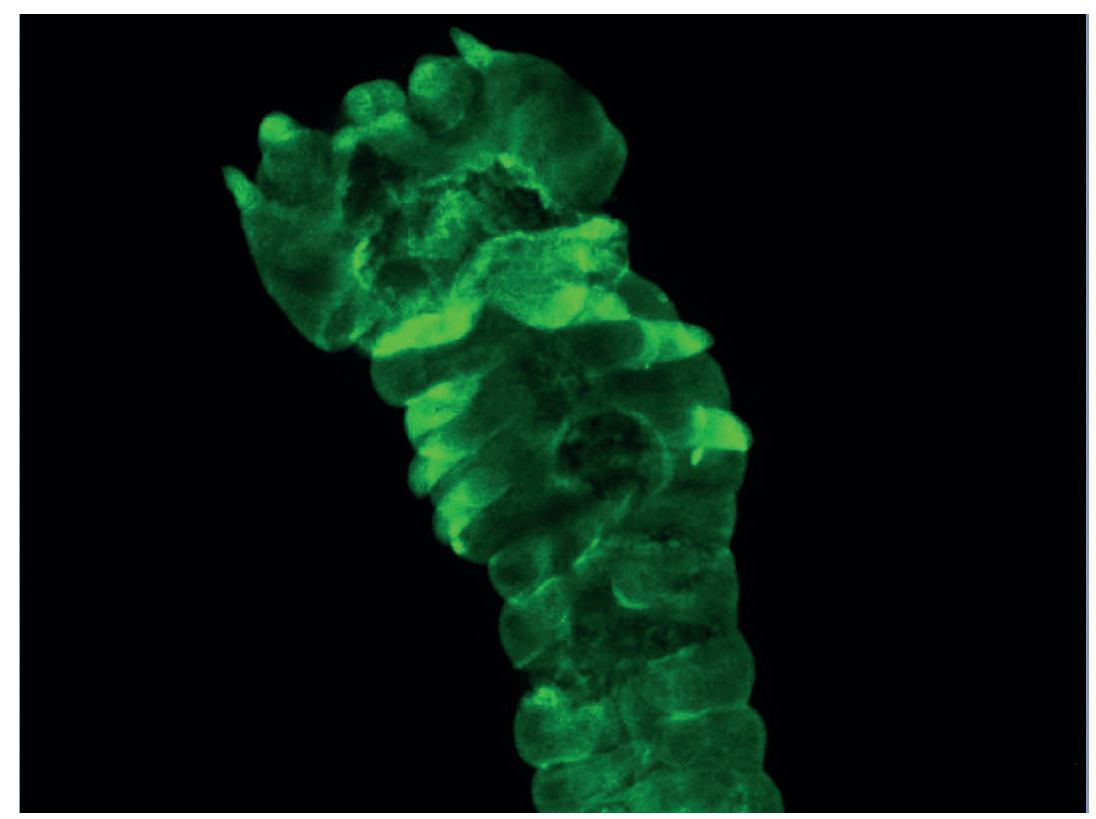

Fig. S20. Second replicate of an EGFP-expressing embryo from the F3 transgenic generation, where the EGFP gene was driven by the Dll319 CRE. EGFP was visualized through the use of anti-EGFP antibodies. 

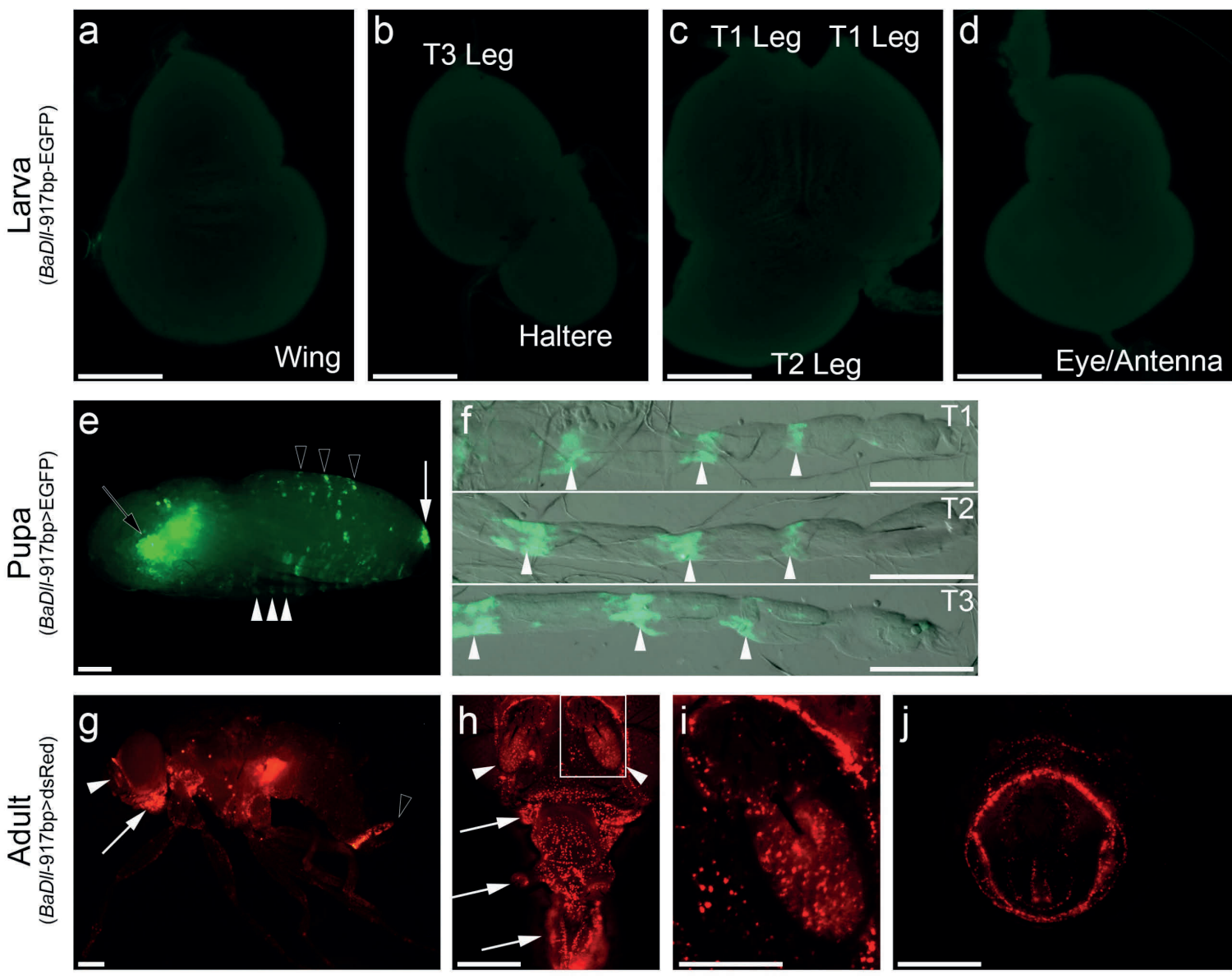

1289

1290

1291

1292

1293

1294

1295

1296

1297

1298

1299

1300

1301

1302

1303

1304

1305

1306

1307

1308

1309

1310

Fig. S21: Cross-species reporter assay of Dll319 CRE in D. melanogaster. a-d. Imaginal discs of Dll319-EGFP flies. No noticeable enhancer activity is detected at this stage. e,f. Dll319 CRE activity during the pupal stage as visualized by Dll319-Gal4>UAS-EGFP. e. Enhancer activity is detected in the pupal legs (white arrowheads), genitalia (white arrow), and in the abdomen (black arrowheads). EGFP in the eye (black arrow) is transgenic marker expression. f. Closeup images of the pupal legs, showing the enhancer activity in the tarsal segments (white arrowheads). g-j. Dll319 CRE activity at the adult stage visualized by Dll319-Gal4>UASdsRed. g. Dll319 CRE drives low ubiquitous ectodermal expression, with increased expression in the adult antennae (white arrowhead), mouthparts (white arrow), and genitalia (black arrowhead). h. Close-up of adult head, showing the increased activity in antennae (white arrowheads) and mouthparts (white arrows). i. Close-up of antenna enhancer activity within the area indicated by the white box in $\mathbf{h}$. $\mathbf{j}$. Close-up of enhancer activity in the adult genitalia. A lack of enhancer activity during the last larval stage may be due to the nature of this enhancer or a limitation of testing the activity of this enhancer in a cross-species setting (or a combination of both). Nonetheless, the presence of increased enhancer activity in multiple tissues, especially with these that are homologous to antennae, suggests that Dll319 contains a pleiotropic CRE. Scale bars indicate $100 \mu \mathrm{m}(\mathbf{a}-\mathbf{d}, \mathbf{f}, \mathbf{i})$ and $200 \mu \mathrm{m}(\mathbf{e}, \mathbf{g}, \mathbf{h}, \mathbf{j})$. 
bioRxiv preprint doi: https//doi.org/10.1101/2021.03.01.429915; this version posted March 1, 2021. The copyright holder for this preprint (which was not certified by peer review) is the author/funder, who has granted bioRxiv a license to display the preprint in perpetuity. It is made available under aCC-BY 4.0 International license.
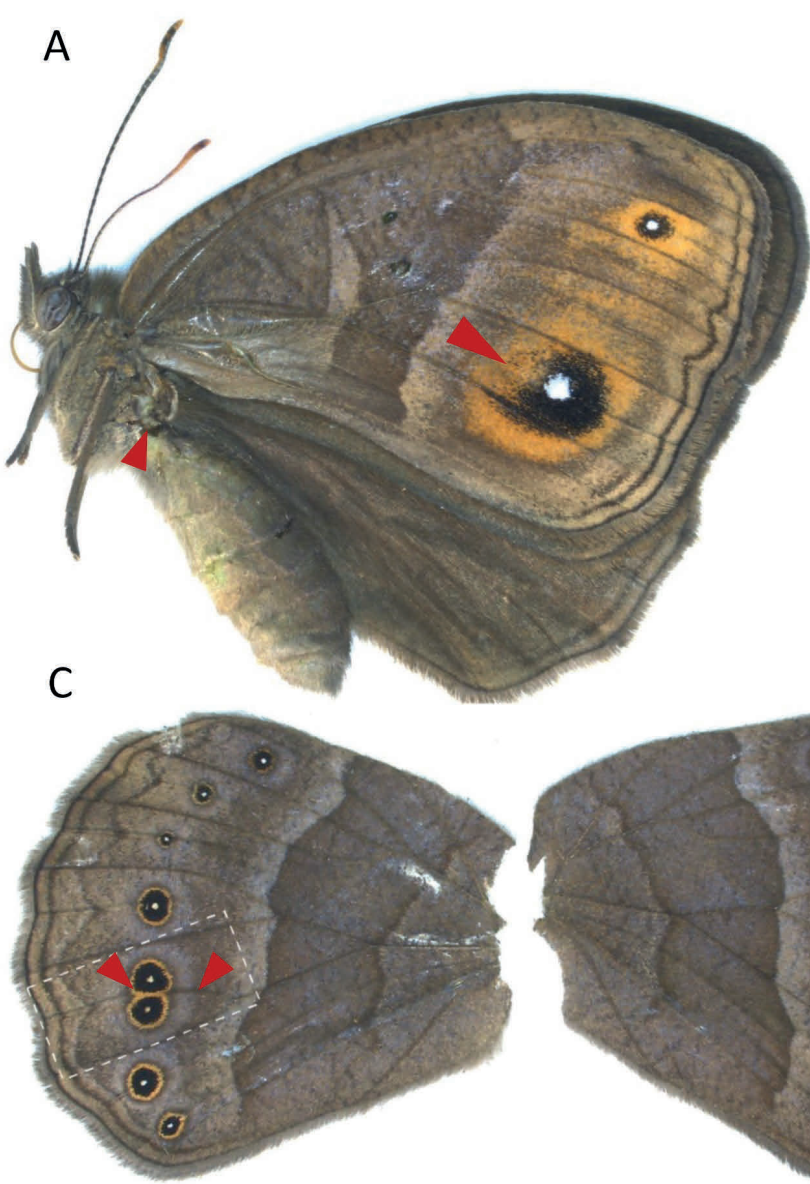

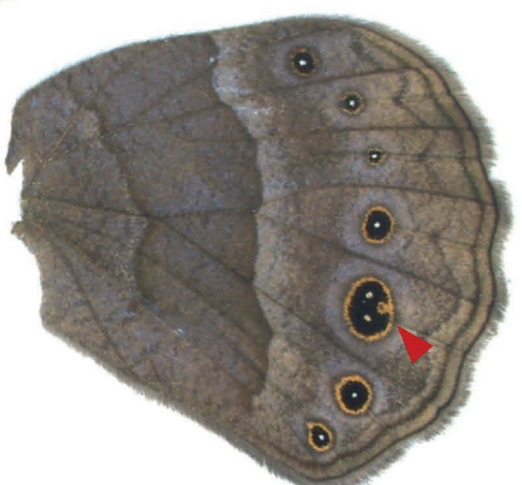

B
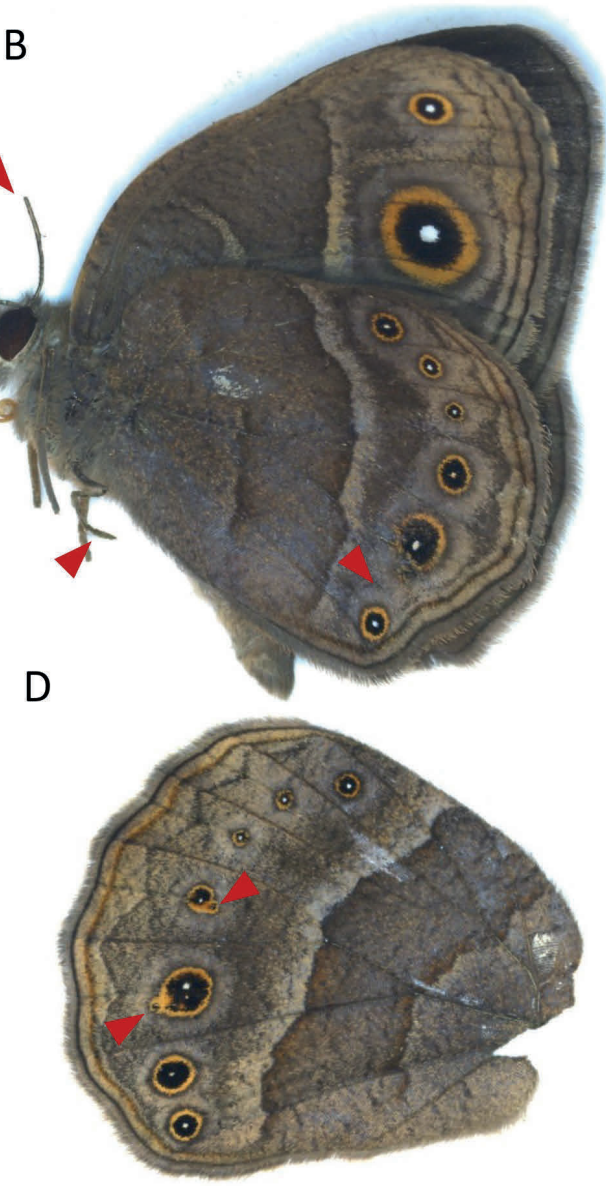

1314

1315

1316

1317

1318

1319

1320

1321

Fig. S22. sal CRE (sal740) crispants phenotypes. A. Loss of hindwing and black pigment in the forewing. B. Loss of eyespot in $\mathrm{Cu} 2$ hindwing sector, loss of distal part of the antenna and crooked T3-leg. C. Left wing: Additional vein formation in Cul sector of hindwing with split of $\mathrm{Cu} 1$ eyespot. Right wing: No ectopic vein but also split of $\mathrm{Cu} 1$ eyespot showing two white centres and another eyespot pigment deformity. D. Ectopic eyespot in Cu1 and M3 sector in hindwing. 
bioRxiv preprint doi: https://doi.org/10.1101/2021.03.01.429915; this version posted March 1, 2021. The copyright holder for this preprint (which was not certified by peer review) is the author/funder, who has granted bioRxiv a license to display the preprint in perpetuity. It is made available under aCC-BY 4.0 International license.

1322

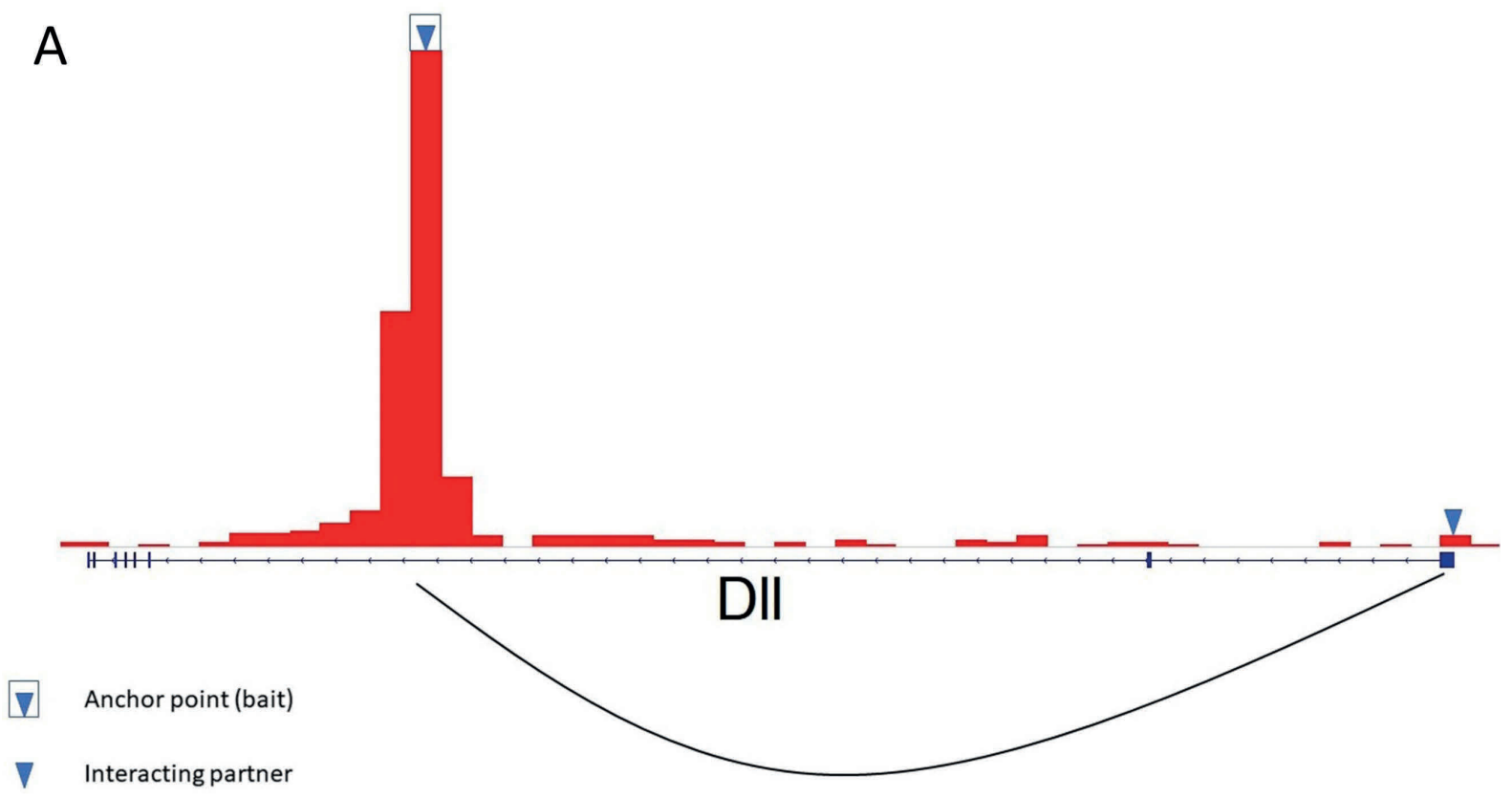

B

Fig. S23. Virtual 4c plot for Dll319 and sal740. (A) The graph around Dll319 region showing 1325 its interaction with Dll promoter region. (B) Graph around sal740 region shows its interaction with sal promoter region 
bioRxiv preprint doi: https://doi.org/10.1101/2021.03 01.429915. this version posted March 1, 2021. The copyright holder for this preprint (which was not certified by peer review) is the author/funder, who has granted bioRxiv a license to display the preprint in perpetuity. It is made available under aCC-BY 4.0 International license.

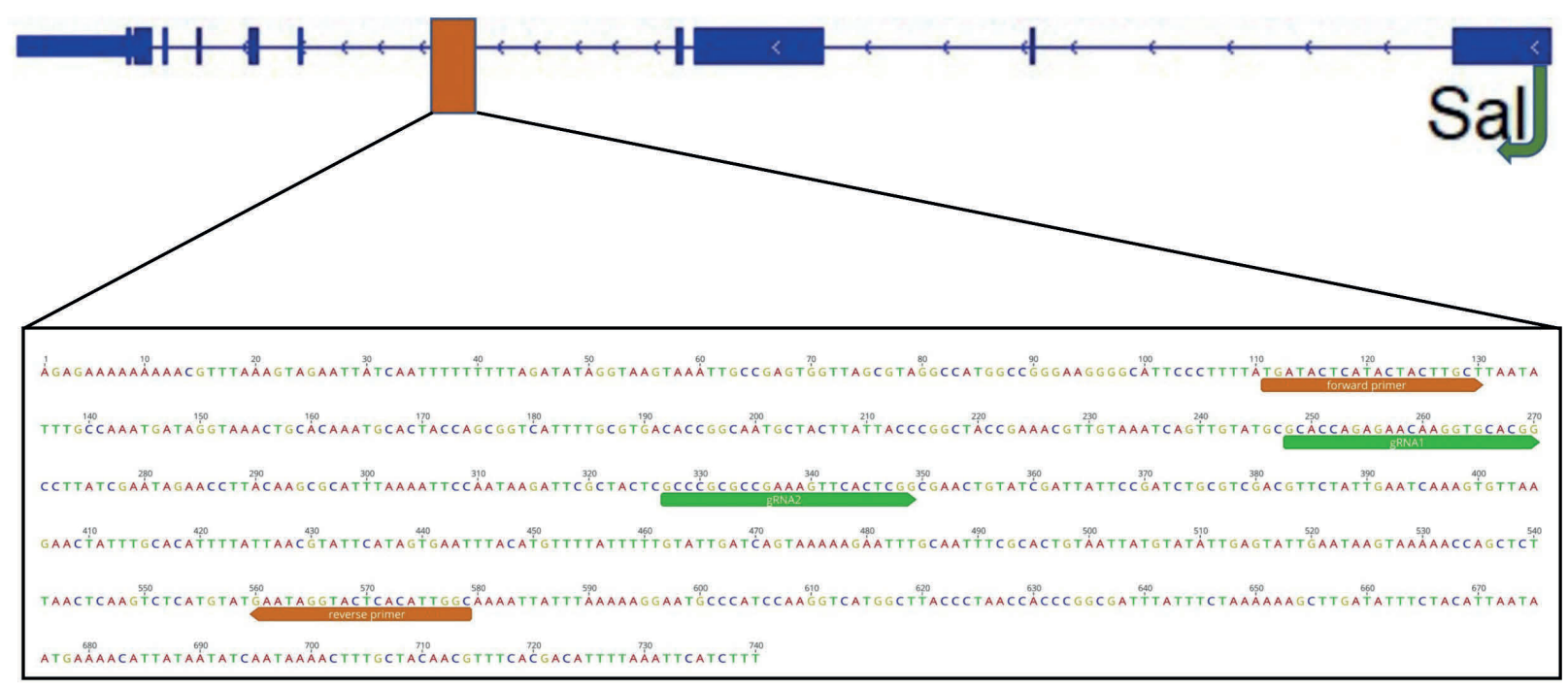

Fig. S24. sal740 CRE region annotated with CRISPR guides and primers used for knockout and genotyping

1330

B

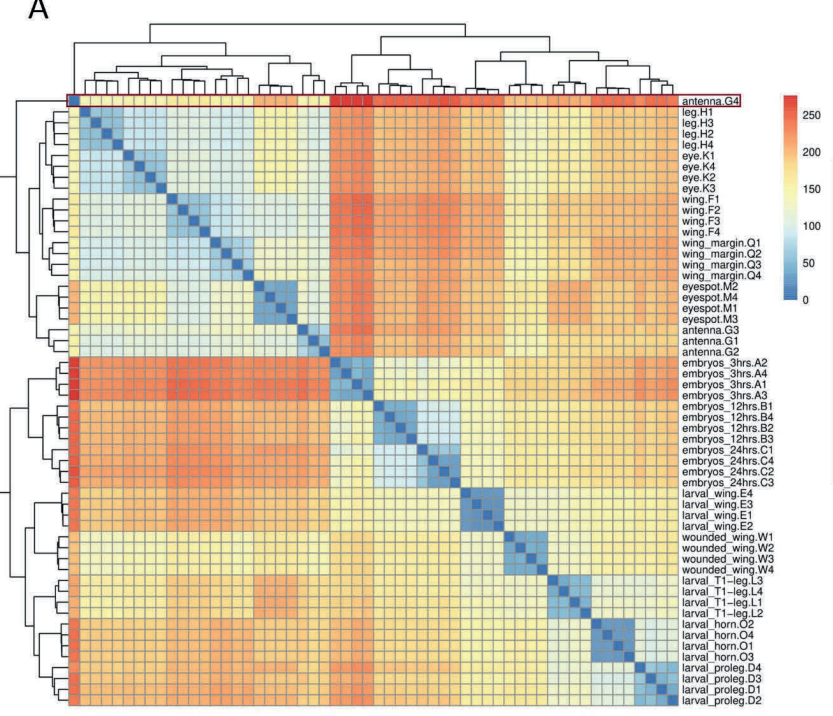

Fig. S25. Sample clustering using an Euclidean distance matrix before and after sample filtering. (A) Initial sample clustering shows antenna. G4 is an outlier. (B) After excluding the outlier (antenna.G4), the replicates from each group cluster together. 
bioRxiv preprint doi: https://doi.org/10.1101/2021.03.01.429915; this version posted March 1, 2021. The copyright holder for this preprint (which was not certified by peer review) is the author/funder, who has granted bioRxiv a license to display the preprint in perpetuity. It is made available under aCC-BY 4.0 International license.

A

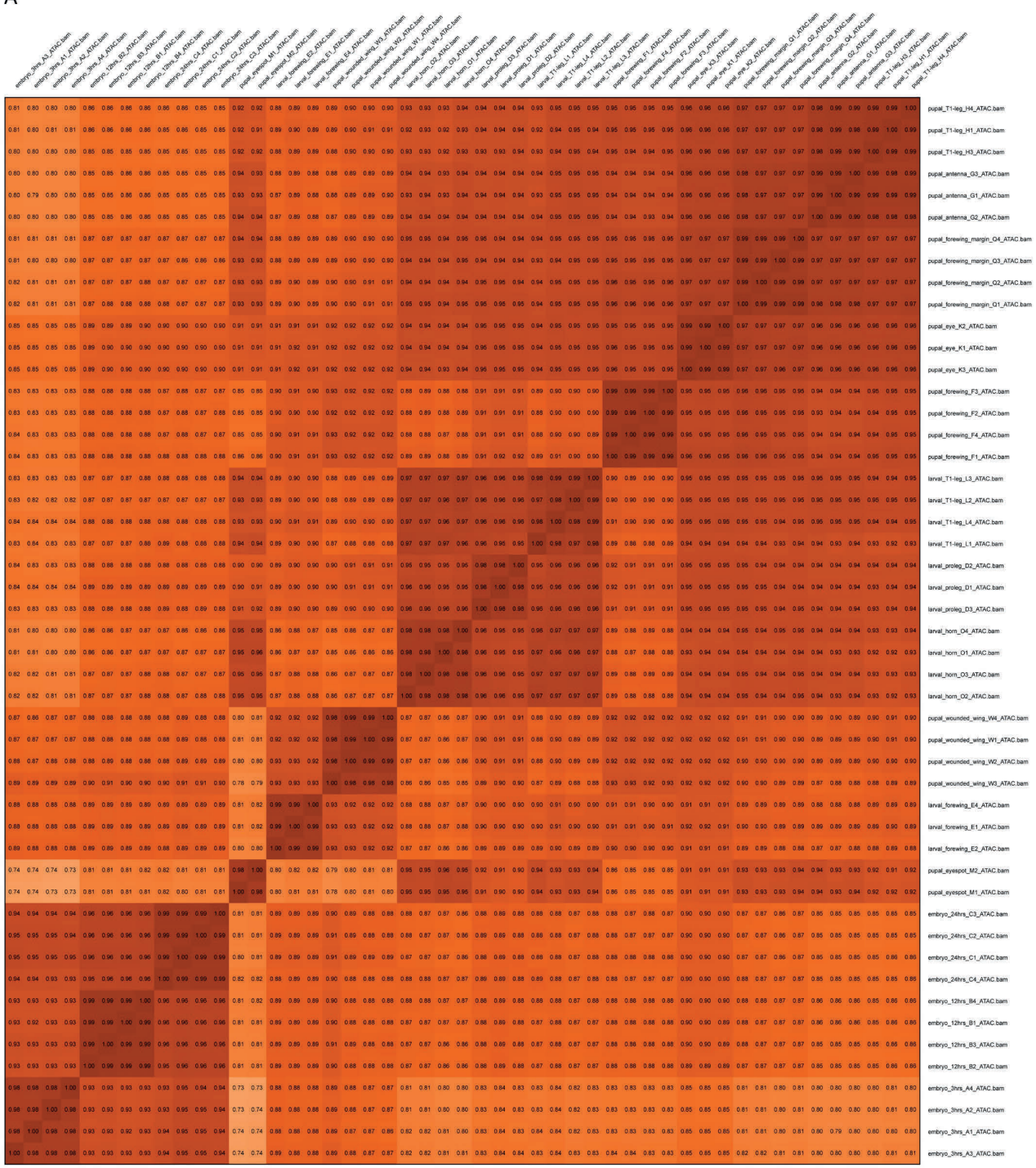

B
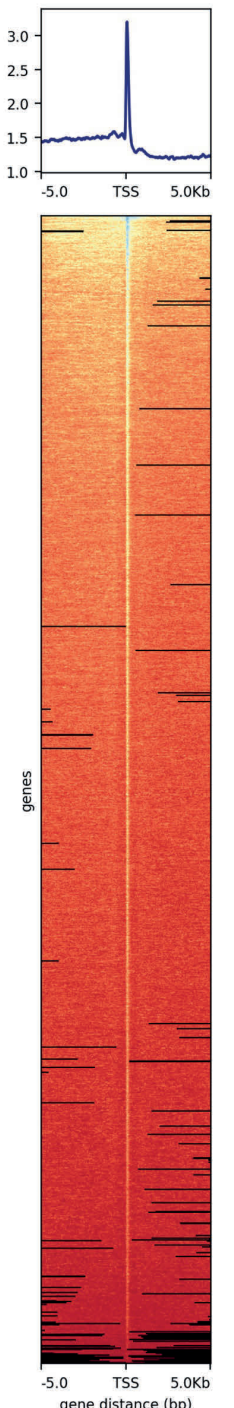

1337 1338

1339 1340 1341 1342 1343 1344 1345 1346

Fig. S26. Quality assessment of ATAC libraries. A. Correlation matrix between the replicates in the group. B. ATAC peaks are highly enriched in Transcription start sites (TSS) and this highlights libraries of good quality. 


\section{Supplementary Tables}

Table S1. Number of injected individuals that displayed developmental defects due to

CRISPR-targeting of the Dll319 CRE.

\begin{tabular}{|l|l|l|l|l|l|l|l|}
\hline $\begin{array}{l}\text { No. eggs } \\
\text { injected }\end{array}$ & $\begin{array}{l}\text { No. } \\
\text { hatched }\end{array}$ & $\begin{array}{l}\text { Survival } \\
\mathbf{3}^{\text {rd }} \\
\text { instar }\end{array}$ & $\begin{array}{l}\text { Leg } \\
\text { mutants }\end{array}$ & $\begin{array}{l}\text { Missing } \\
\text { eyespots }\end{array}$ & $\begin{array}{l}\text { Deformed } \\
\text { antennae }\end{array}$ & $\begin{array}{l}\text { Missing } \\
\text { wings }\end{array}$ & $\begin{array}{l}\text { Pigment } \\
\text { defects }\end{array}$ \\
\hline 366 & 40 & 35 & 1 & 0 & 0 & 0 & 0 \\
\hline 646 & 56 & 51 & 1 & 2 & 0 & 1 & 3 \\
\hline 422 & 87 & 76 & 1 & 2 & 1 & 0 & 4 \\
\hline 797 & 193 & 186 & 1 & 0 & 4 & 0 & 0 \\
\hline
\end{tabular}

Table S2. Primers used for CRISPR guide RNAs and for genotyping crispants.

\begin{tabular}{|c|c|}
\hline Primer description & Sequence (5' to 3') \\
\hline \multicolumn{2}{|l|}{ CRISPR guides for Dll-319bp CRE } \\
\hline Sg1 (- strand) & TGTGCGCAAACTAGTTCCGCGGG \\
\hline Sg2 & AACACACTCACCGTGTTACTTGG \\
\hline Sg3 (- strand) & TAAACATATAATTACTTGGTAGG \\
\hline $\mathrm{Sg} 4$ & TTTAGTTACCATAGTACAGTGGG \\
\hline \multirow[t]{2}{*}{$\begin{array}{l}\text { Primers used for genotyping larval } \\
\text { mutants }\end{array}$} & $\begin{array}{l}\text { FP: } \\
\text { CCTCGGTCTTGAACTGCGTAAAGAAATTTT }\end{array}$ \\
\hline & $\begin{array}{l}\text { RP: } \\
\text { TTTAGTTAGACGGTTCGTTAGTTGGATTGG }\end{array}$ \\
\hline \multirow[t]{4}{*}{$\begin{array}{l}\text { Primers used for genotyping adult } \\
\text { mutants }\end{array}$} & $\begin{array}{l}\text { FP: } \\
\text { ATTGTTGTAATTCGAGTCTAACACTTTATC }\end{array}$ \\
\hline & $\begin{array}{l}\text { RP: } \\
\text { TGACGTAAAACTTTTGCCTTGACACCACCA }\end{array}$ \\
\hline & FP: ATTTTGCATACCTAACGACCCGTGC \\
\hline & RP: CGTAAAACTTTTGCCTTGACACCACC \\
\hline
\end{tabular}


1365

\begin{tabular}{|l|l|}
\hline Primers used for the transgenics & $\begin{array}{l}\text { FP: } \\
\text { CCTCGGTCTTGAACTGCGTAAAGAAATTTT }\end{array}$ \\
\hline RP: \\
TGACGTAAAACTTTTGCCTTGACACCACCA
\end{tabular}

Table S3. Number of injected individuals that displayed developmental defects due to CRISPR-targeting of sal.

\begin{tabular}{|l|l|l|l|l|}
\hline $\begin{array}{l}\text { No. eggs } \\
\text { injected }\end{array}$ & $\begin{array}{l}\text { No. } \\
\text { hatched }\end{array}$ & $\begin{array}{l}\text { Survival } \\
\mathbf{3}^{\text {rd } \text { instar }}\end{array}$ & $\begin{array}{l}\text { No. surviving } \\
\text { until } \\
\text { adulthood }\end{array}$ & $\begin{array}{l}\text { Number of adults } \\
\text { showing phenotype }\end{array}$ \\
\hline 108 & N.A. & N.A. & 51 & 11 \\
\hline 102 & N.A. & N.A. & 23 & 5 \\
\hline
\end{tabular}

Table S4. Number of injected individuals that displayed developmental defects due to CRISPR-targeting of the sal740 CRE

\begin{tabular}{|l|l|l|l|l|l|l|l|l|}
\hline $\begin{array}{l}\text { No. } \\
\text { eggs } \\
\text { injected }\end{array}$ & $\begin{array}{l}\text { No. } \\
\text { hatched }\end{array}$ & $\begin{array}{l}\text { Survival } \\
\mathbf{3}^{\text {rd }} \\
\text { instar }\end{array}$ & $\begin{array}{l}\text { Leg } \\
\text { mutants }\end{array}$ & $\begin{array}{l}\text { Eyespot } \\
\text { mutant }\end{array}$ & $\begin{array}{l}\text { Deformed } \\
\text { antennae }\end{array}$ & $\begin{array}{l}\text { Wing } \\
\text { mutant }\end{array}$ & $\begin{array}{l}\text { Horn } \\
\text { defect }\end{array}$ & $\begin{array}{l}\text { Vein } \\
\text { defect }\end{array}$ \\
\hline 174 & 23 & 17 & 0 & 2 & 1 & 0 & 1 & 1 \\
\hline 116 & 27 & 21 & 1 & 4 & 2 & 1 & 0 & 1 \\
\hline
\end{tabular}


1378 Table S5. Tissue types and number of individuals used for each replicate in RNA-seq

\begin{tabular}{|l|l|}
\hline Tissue & Number of individuals \\
\hline Cu1 control tissue - Nes1 & 20 \\
\hline Cu1 eyespot & 20 \\
\hline M3 control tissue - Nes2 & 20 \\
\hline Wings (larval, pupal 3 h, wounded 24 h) & 15 \\
\hline Embryos (3 h, 12 h, 24 h) & 15 \\
\hline T1- legs (larval, pupal 3 h) & 15 \\
\hline Pupal antennae (3 h) & 15 \\
\hline Pupal eyes (3 h) & 15 \\
\hline Pupal wing margins & 15 \\
\hline Larval prolegs & 15 \\
\hline Larval horns & 15 \\
\hline
\end{tabular}

1379 Dissections were performed from the right and left sides of each animal, except for wounded wings, where only one side of each pupa was wounded.

Table S6. RNA sequencing data. Read-depth and alignment rate

\begin{tabular}{|c|c|c|c|c|}
\hline Group & Sample & $\begin{array}{l}\text { Before } \\
\text { filtration }\end{array}$ & After filtration & $\begin{array}{l}\text { Read mapped } \\
\text { (percentage) }\end{array}$ \\
\hline \multirow{4}{*}{$\begin{array}{l}\text { Embryo } \\
(4 \mathrm{~h})\end{array}$} & A1 & 113835036 & 98548967 & $84535028(85.78)$ \\
\hline & A2 & 85798982 & 72804246 & $62563452(85.93)$ \\
\hline & A3 & 84005872 & 71811396 & $61845018(86.12)$ \\
\hline & A4 & 87964122 & 75009490 & $64255225(85.66)$ \\
\hline \multirow{4}{*}{$\begin{array}{l}\text { Embryo } \\
(12 \mathrm{~h})\end{array}$} & $\mathrm{B} 1$ & 118541088 & 92418462 & $80238385(86.82)$ \\
\hline & B2 & 83149314 & 69051367 & $60021312(86.92)$ \\
\hline & B3 & 84868922 & 71215091 & $62150653(87.27)$ \\
\hline & B4 & 95915936 & 80838013 & $70347725(87.02)$ \\
\hline \multirow{4}{*}{$\begin{array}{l}\text { Embryo } \\
(24 \mathrm{~h})\end{array}$} & $\mathrm{C} 1$ & 104046272 & 83316043 & $73709053(88.47)$ \\
\hline & $\mathrm{C} 2$ & 87307238 & 75070312 & $65274564(86.95)$ \\
\hline & $\mathrm{C} 3$ & 81284220 & 69109463 & $60064998(86.91)$ \\
\hline & $\mathrm{C} 4$ & 94828668 & 79682561 & $69289785(86.96)$ \\
\hline \multirow{2}{*}{$\begin{array}{l}\text { Larval } \\
\text { prolegs }\end{array}$} & D1 & 83276248 & 77847505 & $69820993(89.69)$ \\
\hline & $\mathrm{D} 2$ & 79714564 & 73485189 & $66512225(90.51)$ \\
\hline
\end{tabular}




\begin{tabular}{|c|c|c|c|c|}
\hline & D3 & 81727632 & 75488734 & $66017212(87.45)$ \\
\hline & D4 & 127697360 & 120323993 & $108186292(89.91)$ \\
\hline \multirow{4}{*}{$\begin{array}{l}\text { Larval } \\
\text { forewings }\end{array}$} & E1 & 94157316 & 89083615 & $80816020(90.72)$ \\
\hline & E2 & 87677324 & 82697367 & $75030588(90.73)$ \\
\hline & E3 & 87813076 & 82573316 & $74758890(90.54)$ \\
\hline & E4 & 93771904 & 85869930 & $77692802(90.48)$ \\
\hline \multirow{4}{*}{$\begin{array}{l}\text { Pupal } \\
\text { forewings } \\
(3 \mathrm{~h})\end{array}$} & F1 & 86993380 & 81635451 & $73605012(90.16)$ \\
\hline & F2 & 92558328 & 85676141 & $77497720(90.45)$ \\
\hline & F3 & 110561420 & 100513137 & $90731802(90.27)$ \\
\hline & $\mathrm{F} 4$ & 98618432 & 89622914 & $80778116(90.13)$ \\
\hline \multirow{4}{*}{$\begin{array}{l}\text { Pupal } \\
\text { antennae } \\
(3 \mathrm{~h})\end{array}$} & G1 & 121763488 & 97360783 & $89616569(92.05)$ \\
\hline & G2 & 98867180 & 91442924 & $83616498(91.44)$ \\
\hline & G3 & 110612002 & 100686643 & $93855202(93.22)$ \\
\hline & G4 & 131127280 & 112107640 & $102392344(91.33)$ \\
\hline \multirow{4}{*}{$\begin{array}{l}\text { Pupal T1- } \\
\text { legs }(3 \mathrm{~h})\end{array}$} & $\mathrm{H} 1$ & 82555558 & 73463615 & $66269516(90.21)$ \\
\hline & $\mathrm{H} 2$ & 82664720 & 76726364 & $69433046(90.49)$ \\
\hline & $\mathrm{H} 3$ & 92650310 & 83394624 & $75461955(90.49)$ \\
\hline & $\mathrm{H} 4$ & 103884724 & 95341919 & $86365208(90.58)$ \\
\hline \multirow{4}{*}{$\begin{array}{l}\text { Pupal eyes } \\
(3 \mathrm{~h})\end{array}$} & $\mathrm{K} 1$ & 105415992 & 97797591 & $86952723(88.91)$ \\
\hline & $\mathrm{K} 2$ & 104493966 & 90166098 & $80474351(89.25)$ \\
\hline & $\mathrm{K} 3$ & 126805006 & 119393689 & $106917955(89.55)$ \\
\hline & $\mathrm{K} 4$ & 89001494 & 83262184 & $74215276(89.13)$ \\
\hline \multirow{4}{*}{$\begin{array}{l}\text { Larval T1- } \\
\text { legs }\end{array}$} & $\mathrm{L1}$ & 86355848 & 71592616 & $62684382(87.56)$ \\
\hline & $\mathrm{L} 2$ & 87998220 & 74129624 & $64661129(87.23)$ \\
\hline & L3 & 85044900 & 74009714 & $65079663(87.93)$ \\
\hline & L4 & 85073358 & 72756514 & $64015288(87.99)$ \\
\hline \multirow{4}{*}{$\begin{array}{l}\text { Pupal } \\
\text { eyespots } \\
(3 h)\end{array}$} & M1 & 95689310 & 79421201 & $71472125(89.99)$ \\
\hline & $\mathrm{M} 2$ & 88548194 & 72248301 & $64941843(89.89)$ \\
\hline & M3 & 99417446 & 82401746 & $74051771(89.87)$ \\
\hline & M4 & 83145168 & 68910114 & $61942120(89.89)$ \\
\hline \multirow{4}{*}{$\begin{array}{l}\text { Pupal } \\
\text { eyespot } \\
\text { control } \\
\text { tissue } \\
\text { (Nes2) (3h) } \\
\end{array}$} & N1 & 84383612 & 67629139 & $61068234(90.30)$ \\
\hline & $\mathrm{N} 2$ & 94301260 & 77361040 & $69687990(90.08)$ \\
\hline & N3 & 82445922 & 67265063 & $60665549(90.19)$ \\
\hline & N4 & 88114168 & 72856592 & $65653903(90.11)$ \\
\hline \multirow{4}{*}{$\begin{array}{l}\text { Larval } \\
\text { horns }\end{array}$} & $\mathrm{O} 1$ & 99068014 & 85624813 & $75362272(88.01)$ \\
\hline & $\mathrm{O} 2$ & 91060940 & 79279017 & $69618673(87.81)$ \\
\hline & $\mathrm{O} 3$ & 82291644 & 71445496 & $62786392(87.88)$ \\
\hline & $\mathrm{O} 4$ & 90492250 & 79350706 & $69725988(87.87)$ \\
\hline \multirow{3}{*}{$\begin{array}{l}\text { Pupal } \\
\text { eyespot } \\
\text { control }\end{array}$} & P1 & 82963650 & 72783137 & $65682543(90.24)$ \\
\hline & $\mathrm{P} 2$ & 80007172 & 72558427 & $65495973(90.27)$ \\
\hline & P3 & 88945496 & 82952035 & $74929608(90.33)$ \\
\hline
\end{tabular}




\begin{tabular}{|l|l|l|l|l|}
\hline $\begin{array}{l}\text { tissue } \\
\text { (Nes1) (3h) }\end{array}$ & P4 & 87810090 & 82518479 & $73776623(89.41)$ \\
\hline $\begin{array}{l}\text { Pupal } \\
\text { forewing } \\
\text { margins } \\
\mathbf{( 3 ~ h )}\end{array}$ & Q1 & 95209370 & 84816919 & $76522011(90.22)$ \\
\cline { 2 - 5 } & Q2 & 92102414 & 83759967 & $75370417(89.98)$ \\
\cline { 2 - 5 } & Q3 & 108138096 & 93532198 & $83304314(89.06)$ \\
\cline { 2 - 5 } $\begin{array}{l}\text { Wounded } \\
\text { pupal } \\
\text { wings } \begin{array}{l}\text { Q4 } \\
\text { h) }\end{array}\end{array}$ & W1 & 89856780 & 78373499 & $70107705(89.45)$ \\
\cline { 2 - 5 } & W2 & 103749366 & 98026397 & $87874345(89.64)$ \\
\cline { 2 - 5 } & W3 & 83506698 & 78712471 & $71236861(90.50)$ \\
\hline
\end{tabular}

Table S7. Tissues types and numbers of individuals used for each replicate in ATAC-seq

\begin{tabular}{|l|l|}
\hline Tissue & Number of individuals \\
\hline Cu1 eyespot & 25 \\
\hline Wings (larval, pupal 3 h, wounded 24 h) & 20 \\
\hline Embryos (3 h, 12 h, 24 h) & 15 \\
\hline T1- legs (larval, pupal 3 h) & 20 \\
\hline Pupal antennae (3 h) & 20 \\
\hline Pupal eyes (3 h) & 20 \\
\hline Pupal wing margins & 20 \\
\hline Larval prolegs & 20 \\
\hline Larval horns & 20 \\
\hline
\end{tabular}

1390 Dissections were performed from the right and left sides of each animal, except for wounded wings, where only one side of each pupa was wounded.

Table S8: ATAC-Seq reads. Read depth and FRiP score

\begin{tabular}{|l|l|l|l|l|}
\hline \multirow{2}{*}{ Group } & Sample & $\begin{array}{l}\text { Reads mapped } \\
\text { to genome }\end{array}$ & $\begin{array}{l}\text { Reads mapped } \\
\text { to peaks }\end{array}$ & FRiP score \\
\hline \multirow{3}{*}{ Embryos (4 h) } & A1 & 7929162 & 7069208 & 0.892 \\
\cline { 2 - 5 } & A2 & 8722848 & 7650722 & 0.878 \\
\cline { 2 - 5 } & A3 & 7590222 & 6645944 & 0.876 \\
\hline
\end{tabular}




\begin{tabular}{|c|c|c|c|c|}
\hline & A4 & 8079972 & 7027172 & 0.87 \\
\hline \multirow{4}{*}{$\begin{array}{l}\text { Embryos (12 } \\
\text { h) }\end{array}$} & B1 & 28845464 & 24414192 & 0.847 \\
\hline & B2 & 21022574 & 17806982 & 0.848 \\
\hline & B3 & 26855374 & 22789314 & 0.849 \\
\hline & B4 & 24438812 & 20817352 & 0.852 \\
\hline \multirow{4}{*}{$\begin{array}{l}\text { Embryos (24 } \\
\text { h) }\end{array}$} & $\mathrm{C} 1$ & 23947046 & 20470934 & 0.855 \\
\hline & $\mathrm{C} 2$ & 19317116 & 16720430 & 0.866 \\
\hline & C3 & 17459032 & 15060032 & 0.863 \\
\hline & $\mathrm{C} 4$ & 23499084 & 20482478 & 0.872 \\
\hline \multirow{3}{*}{ Larval prolegs } & D1 & 17098004 & 14066208 & 0.823 \\
\hline & D2 & 16925178 & 13848684 & 0.819 \\
\hline & D3 & 18225832 & 14975016 & 0.822 \\
\hline \multirow{3}{*}{$\begin{array}{l}\text { Larval } \\
\text { forewings }\end{array}$} & E1 & 22238552 & 19258772 & 0.867 \\
\hline & E2 & 22896714 & 20094916 & 0.878 \\
\hline & E4 & 22130896 & 19302416 & 0.873 \\
\hline \multirow{4}{*}{$\begin{array}{l}\text { Pupal } \\
\text { forewings } \\
(3 \mathrm{~h})\end{array}$} & F1 & 32928940 & 28260602 & 0.859 \\
\hline & F2 & 25811542 & 22215800 & 0.861 \\
\hline & F3 & 30779202 & 26438266 & 0.859 \\
\hline & F4 & 30407764 & 26060672 & 0.858 \\
\hline \multirow{3}{*}{$\begin{array}{l}\text { Pupal } \\
\text { antennae } \\
(3 \mathrm{~h})\end{array}$} & G1 & 39990330 & 33025110 & 0.826 \\
\hline & $\mathrm{G} 2$ & 26276830 & 21934216 & 0.835 \\
\hline & G3 & 35808400 & 29831484 & 0.834 \\
\hline \multirow{3}{*}{$\begin{array}{l}\text { Pupal T1-legs } \\
(3 \mathrm{~h})\end{array}$} & H1 & 35962956 & 29719496 & 0.827 \\
\hline & H3 & 30691458 & 25407180 & 0.828 \\
\hline & $\mathrm{H} 4$ & 32904694 & 27491442 & 0.836 \\
\hline \multirow{3}{*}{$\begin{array}{l}\text { Pupal eyes } \\
(3 \mathrm{~h})\end{array}$} & $\mathrm{K} 1$ & 27369070 & 23057554 & 0.843 \\
\hline & $\mathrm{K} 2$ & 25115380 & 21124918 & 0.842 \\
\hline & K3 & 23566544 & 19761176 & 0.839 \\
\hline \multirow{4}{*}{ Larval T1-legs } & L1 & 24453864 & 20554604 & 0.841 \\
\hline & L2 & 28109100 & 22717706 & 0.809 \\
\hline & L3 & 27081264 & 22121078 & 0.817 \\
\hline & L4 & 22582662 & 18430048 & 0.817 \\
\hline \multirow{2}{*}{$\begin{array}{l}\text { Pupal eyespots } \\
(3 \mathrm{~h})\end{array}$} & M1 & 23591594 & 19145932 & 0.812 \\
\hline & M2 & 24294062 & 20029744 & 0.825 \\
\hline \multirow{4}{*}{ Larval horns } & $\mathrm{O} 1$ & 21485294 & 17388048 & 0.81 \\
\hline & $\mathrm{O} 2$ & 20946732 & 16941090 & 0.809 \\
\hline & $\mathrm{O} 3$ & 19939442 & 16082748 & 0.807 \\
\hline & $\mathrm{O} 4$ & 27568916 & 21767434 & 0.79 \\
\hline \multirow{4}{*}{$\begin{array}{l}\text { Pupal } \\
\text { forewing } \\
\text { margins (3 h) }\end{array}$} & Q1 & 79547324 & 65788012 & 0.828 \\
\hline & Q2 & 31692538 & 26044216 & 0.822 \\
\hline & Q3 & 24654044 & 20246276 & 0.822 \\
\hline & Q4 & 25965642 & 21625304 & 0.833 \\
\hline
\end{tabular}




\begin{tabular}{|l|l|l|l|l|}
\hline \multirow{3}{*}{$\begin{array}{l}\text { Wounded } \\
\text { pupal wings } \\
(\mathbf{2 4} \text { h) }\end{array}$} & $\mathrm{W} 1$ & 30988206 & 26493042 & 0.855 \\
\cline { 2 - 5 } & $\mathrm{W} 2$ & 36814878 & 31509656 & 0.856 \\
\cline { 2 - 5 } & $\mathrm{W} 3$ & 49790726 & 43261278 & 0.869 \\
\cline { 2 - 5 } & $\mathrm{W} 4$ & 27833492 & 23647830 & 0.85 \\
\hline
\end{tabular}

\section{References}

1. W. J. Glassford, W. C. Johnson, N. R. Dall, S. J. Smith, Y. Liu, W. Boll, M. Noll, M. Rebeiz, Co-option of an Ancestral Hox-Regulated Network Underlies a Recently Evolved Morphological Novelty. Dev. Cell. 34, 520-531 (2015).

2. S. B. Carroll, J. Gates, D. N. Keys, S. W. Paddock, G. E. Panganiban, J. E. Selegue, J. a Williams, Pattern formation and eyespot determination in butterfly wings. Science. 265, 109-14 (1994).

3. S. V Saenko, V. French, P. M. Brakefield, P. Beldade, Conserved developmental processes and the formation of evolutionary novelties: examples from butterfly wings. Philos. Trans. R. Soc. Lond. B. Biol. Sci. 363, 1549-55 (2008).

4. L. I. Held, Rethinking Butterfly Eyespots. Evol. Biol. 40, 158-168 (2013).

5. A. Monteiro, G. Glaser, S. Stockslager, N. Glansdorp, D. Ramos, Comparative insights into questions of lepidopteran wing pattern homology. BMC Dev. Biol. 6, 1-13 (2006).

6. H. Connahs, S. Tlili, J. van Creij, T. Y. J. Loo, T. Das Banerjee, T. E. Saunders, A. diffusion process. Dev. 146, 1-12 (2019).

7. J. M. Musser, G. P. Wagner, Character trees from transcriptome data: Origin and individuation of morphological characters and the so-called "species signal." J. Exp. Zool. Part B Mol. Dev. Evol. 324, 588-604 (2015).

8. M. I. Love, W. Huber, S. Anders, Moderated estimation of fold change and dispersion for RNA-seq data with DESeq2. Genome Biol. 15, 1-21 (2014).

9. R. Suzuki, H. Shimodaira, Pvclust: An R package for assessing the uncertainty in hierarchical clustering. Bioinformatics. 22, 1540-1542 (2006).

10. N. Özsu, A. Monteiro, Wound healing, calcium signaling, and other novel pathways are associated with the formation of butterfly eyespots. BMC Genomics. 18 (2017), doi:10.1186/s12864-017-4175-7.

11. J. D. Uhl, A. Zandvakili, B. Gebelein, A Hox Transcription Factor Collective Binds a Highly Conserved Distal-less cis-Regulatory Module to Generate Robust Transcriptional Outcomes. PLoS Genet. 12, 1-26 (2016).

12. J. T. Wagner-Bernholz, O. Wilson, G. Gibson, R. Schuh, W. J. Gehring, Identification of target genes of the homeotic gene Antennapedia by enhancer detection (Genes and Development 5 (2467-2480)). Genes Dev. 6, 328 (1992). 
14. J. C. Oliver, X. L. Tong, L. F. Gall, W. H. Piel, A. Monteiro, A Single Origin for Nymphalid Butterfly Eyespots Followed by Widespread Loss of Associated Gene Expression. PLoS Genet. 8 (2012), doi:10.1371/journal.pgen.1002893.

15. Y. Matsuoka, A. Monteiro, Hox genes are essential for the development of novel serial homologous eyespots on the wings of Bicyclus anynana butterflies. Gentics, iyaa005 (2020).

16. T. Das Banerjee, A. Monteiro, Molecular mechanisms underlying simplification of venation patterns in holometabolous insects. Dev. dev.196394 (2020), doi:10.1242/dev.196394.

17. L. Zhang, R. D. Reed, Genome editing in butterflies reveals that spalt promotes and Distal-less represses eyespot colour patterns. Nat. Commun. 7 (2016), doi:10.1038/ncomms11769.

18. C. R. Brunetti, J. E. Selegue, A. Monteiro, V. French, P. M. Brakefield, S. B. Carroll, The generation and diversification of butterfly eyespot color patterns. Curr. Biol. 11, 1578-1585 (2001).

19. S. V. Saenko, M. S. P. Marialva, P. Beldade, Involvement of the conserved Hox gene Antennapedia in the development and evolution of a novel trait. Evodevo. 2, 9 (2011).

20. G. Panganiban, Distal-less Function During Drosophila Appendage and Sense Organ Development. Dev. Dyn. 562, 554-562 (2000).

21. B. S. Emerald, S. M. Cohen, Spatial and temporal regulation of the homeotic selector gene Antennapedia is required for the establishment of leg identity in Drosophila. Dev. Biol. 267, 462-472 (2004).

22. Y. T. Lai, K. D. Deem, F. Borràs-Castells, N. Sambrani, H. Rudolf, K. Suryamohan, E. El-Sherif, M. S. Halfon, D. J. McKay, Y. Tomoyasu, Enhancer identification and activity evaluation in the red flour beetle, Tribolium castaneum. Dev. 145 (2018), doi:10.1242/dev.160663.

23. G. Panganiban, J. L. R. Rubenstein, Developmental functions of the Distal-less/Dlx homeobox genes. Development. 129, 4371-86 (2002).

24. H. S. Bruce, N. H. Patel, Knockout of crustacean leg patterning genes suggests that insect wings and body walls evolved from ancient leg segments (2020), vol. 4.

25. C. M. Clark-Hachtel, Y. Tomoyasu, Two sets of candidate crustacean wing homologues and their implication for the origin of insect wings. Nat. Ecol. Evol. 4, 1694-1702 (2020).

26. G. Sabarís, I. Laiker, E. Preger-Ben Noon, N. Frankel, Actors with Multiple Roles: Pleiotropic Enhancers and the Paradigm of Enhancer Modularity. Trends Genet. 35, 423-433 (2019).

27. B. Prud'homme, N. Gompel, S. B. Carroll, Emerging principles of regulatory evolution. Light Evol. 1, 109-127 (2007).

28. A. Monteiro, O. Podlaha, Wings, horns, and butterfly eyespots: how do complex traits evolve? PLoS Biol. 7, e37 (2009).

29. H. Li, R. Durbin, Fast and accurate short read alignment with Burrows-Wheeler transform. Bioinformatics. 25, 1754-1760 (2009).

30. H. Li, B. Handsaker, A. Wysoker, T. Fennell, J. Ruan, N. Homer, G. Marth, G. Abecasis, R. Durbin, The Sequence Alignment/Map format and SAMtools. 
Bioinformatics. 25, 2078-2079 (2009).

31. A. R. Quinlan, I. M. Hall, BEDTools: A flexible suite of utilities for comparing genomic features. Bioinformatics. 26, 841-842 (2010).

32. Y. Zhang, T. Liu, C. A. Meyer, J. Eeckhoute, D. S. Johnson, B. E. Bernstein, C. Nussbaum, R. M. Myers, M. Brown, W. Li, X. S. Shirley, Model-based analysis of ChIP-Seq (MACS). Genome Biol. 9 (2008), doi:10.1186/gb-2008-9-9-r137.

33. Y. Naito, K. Hino, H. Bono, K. Ui-Tei, CRISPRdirect: Software for designing CRISPR/Cas guide RNA with reduced off-target sites. Bioinformatics. 31, 1120-1123 (2015).

34. K. N. Eckermann, H. M. M. Ahmed, M. KaramiNejadRanjbar, S. Dippel, C. E. Ogaugwu, P. Kitzmann, M. D. Isah, E. A. Wimmer, Hyperactive piggyBac transposase improves transformation efficiency in diverse insect species. Insect Biochem. Mol. Biol. 98, 16-24 (2018).

35. C. J. Evans, J. M. Olson, K. T. Ngo, E. Kim, N. E. Lee, E. Kuoy, A. N. Patananan, D. Sitz, P. T. Tran, M. T. Do, K. Yackle, A. Cespedes, V. Hartenstein, G. B. Call, U. Banerjee, G-TRACE: Rapid Gal4-based cell lineage analysis in Drosophila. Nat. Methods. 6, 603-605 (2009).

36. B. Bushnell, BBMap: A Fast, Accurate, Splice-Aware Aligner. United States N. $p$ (2014), (available at https://www.osti.gov/biblio/1241166-bbmap-fast-accurate-spliceaware-aligner).

37. E. Kopylova, L. Noé, H. Touzet, SortMeRNA: Fast and accurate filtering of ribosomal RNAs in metatranscriptomic data. Bioinformatics. 28, 3211-3217 (2012).

38. M. Pertea, D. Kim, G. M. Pertea, J. T. Leek, S. L. Salzberg, Transcript-level expression analysis of RNA-seq experiments with HISAT, StringTie and Ballgown. Nat. Protoc. 11, 1650-1667 (2016).

39. M. S. Campbel, C. Holt, B. Moore, M. Yandell, Genome Annotation and Curation Using MAKER and MAKER-P (2008), vol. 48.

40. B. J. Haas, A. Papanicolaou, M. Yassour, M. Grabherr, D. Philip, J. Bowden, M. B. Couger, D. Eccles, B. Li, M. D. Macmanes, M. Ott, J. Orvis, N. Pochet, F. Strozzi, N. Weeks, R. Westerman, T. William, C. N. Dewey, R. Henschel, R. D. Leduc, N. Friedman, A. Regev, De novo transcript sequence recostruction from RNA-Seq: reference generation and analysis with Trinity (2013), vol. 8.

41. C. R. Fisher, J. L. Wegrzyn, E. L. Jockusch, Co-option of wing-patterning genes underlies the evolution of the treehopper helmet. Nat. Ecol. Evol. 4, 250-260 (2020).

42. R Core Team, R: A language and environment for statistical computing (2020).

43. M. R. Corces, A. E. Trevino, E. G. Hamilton, P. G. Greenside, N. A. SinnottArmstrong, S. Vesuna, A. T. Satpathy, A. J. Rubin, K. S. Montine, B. Wu, A. Kathiria, S. W. Cho, M. R. Mumbach, A. C. Carter, M. Kasowski, L. A. Orloff, V. I. Risca, A. Kundaje, P. A. Khavari, T. J. Montine, W. J. Greenleaf, H. Y. Chang, An improved ATAC-seq protocol reduces background and enables interrogation of frozen tissues. Nat. Methods. 14, 959-962 (2017).

44. A. P. Boyle, J. Guinney, G. E. Crawford, T. S. Furey, F-Seq: A feature density estimator for high-throughput sequence tags. Bioinformatics. 24, 2537-2538 (2008).

45. Y. Liao, G. K. Smyth, W. Shi, FeatureCounts: An efficient general purpose program 
for assigning sequence reads to genomic features. Bioinformatics. 30, 923-930 (2014).

46. F. Ramírez, F. Dündar, S. Diehl, B. A. Grüning, T. Manke, DeepTools: A flexible platform for exploring deep-sequencing data. Nucleic Acids Res. 42, 187-191 (2014).

47. N. C. Durand, M. S. Shamim, I. Machol, S. S. P. Rao, M. H. Huntley, E. S. Lander, E. L. Aiden, A. Mathematics, Juicer provides a one-click system for analyzing loopresolution Hi-C experiments. Cell Syst. 3, 95-98 (2018).

48. J. Ray, P. R. Munn, A. Vihervaara, J. J. Lewis, A. Ozer, C. G. Danko, J. T. Lis, Chromatin conformation remains stable upon extensive transcriptional changes driven by heat shock. Proc. Natl. Acad. Sci. U. S. A. 116, 19431-19439 (2019).

49. R. W. Nowell, B. Elsworth, V. Oostra, B. J. Zwaan, C. W. Wheat, M. Saastamoinen, I. J. Saccheri, A. E. van't Hof, B. R. Wasik, H. Connahs, M. L. Aslam, S. Kumar, R. J. Challis, A. Monteiro, P. M. Brakefield, M. Blaxter, A high-coverage draft genome of the mycalesine butterfly Bicyclus anynana. Gigascience. 6, 1-7 (2017).

50. P. Beldade, S. V. Saenko, N. Pul, A. D. Long, A gene-based linkage map for Bicyclus anynana butterflies allows for a comprehensive analysis of synteny with the lepidopteran reference genome. PLoS Genet. 5 (2009), doi:10.1371/journal.pgen.1000366.

51. J. Catchen, A. Amores, S. Bassham, G3\&amp;\#58; Genes $\mid$ Genomes $\mid$ Genetics, in press, doi:10.1534/g3.120.401485.

52. F. A. Simão, R. M. Waterhouse, P. Ioannidis, E. V. Kriventseva, E. M. Zdobnov, BUSCO: Assessing genome assembly and annotation completeness with single-copy orthologs. Bioinformatics. 31, 3210-3212 (2015).

53. P. Jones, D. Binns, H. Y. Chang, M. Fraser, W. Li, C. McAnulla, H. McWilliam, J. Maslen, A. Mitchell, G. Nuka, S. Pesseat, A. F. Quinn, A. Sangrador-Vegas, M. Scheremetjew, S. Y. Yong, R. Lopez, S. Hunter, InterProScan 5: Genome-scale protein function classification. Bioinformatics. 30, 1236-1240 (2014).

54. J. Dainat, AGAT: Another Gff Analysis Toolkit to handle annotations in any GTF/GFF format.(Version v0.4.0) (2020), doi:10.5281/ZENODO.4205393.

55. B. Buchfink, C. Xie, D. H. Huson, Fast and sensitive protein alignment using DIAMOND. Nat. Methods. 12, 59-60 (2014).

56. S. Götz, J. M. García-Gómez, J. Terol, T. D. Williams, S. H. Nagaraj, M. J. Nueda, M. Robles, M. Talón, J. Dopazo, A. Conesa, High-throughput functional annotation and data mining with the Blast2GO suite. Nucleic Acids Res. 36, 3420-3435 (2008). 